UNIVERSIDADE DE SÃO PAULO

PROGRAMA DE PÓS-GRADUAÇÃO EM CIÊNCIA AMBIENTAL

\author{
SIMONE MIKETEN
}

AGRICULTURA E CONSERVAÇÃO AMBIENTAL: O CASO DA APA BORORÉ-COLÔNIA NO MUNICÍPIO DE SÃO PAULO 


\section{SIMONE MIKETEN}

\section{AGRICULTURA E CONSERVAÇ̃̃O AMBIENTAL: O CASO DA APA BORORÉ-COLÔNIA NO MUNICÍPIO DE SÃO PAULO}

Dissertação apresentada ao Programa de PósGraduação em Ciência Ambiental (PROCAM) da Universidade de São Paulo para obtenção do título de Mestre em Ciência Ambiental

Orientador: Prof. Dr. Luiz Carlos Beduschi Filho

Versão Revisada

(versão revisada disponível na biblioteca da Unidade que aloja o Programa e na Biblioteca Digital de Teses e Dissertações da USP)

\section{SÃO PAULO}


AUTORIZO A REPRODUÇÃO E DIVULGAÇÃO TOTAL OU PARCIAL DESTE TRABALHO, POR QUALQUER MEIO CONVENCIONAL OU ELETRÔNICO, PARA FINS DE ESTUDO E PESQUISA, DESDE QUE CITADA A FONTE.

FICHA CATALOGRÁFICA

MIKETEN, Simone

Agricultura e conservação ambiental: o caso da APA BororéColônia no município de São Paulo. Simone Miketen; orientador Luiz Carlos Beduschi Filho. São Paulo, 2013

169 f.: il.; $30 \mathrm{~cm}$.

Dissertação (Mestrado) - Programa de Pós-Graduação em Ciência Ambiental da Universidade de São Paulo

1. Agricultura Urbana e Periurbana 2. Conservação Ambiental 3. Agroecologia 
FOLHA DE APROVAÇÃO 
Dedicado à luz de minha mãe Lúcia e de meu pai Miketen. 


\section{AGRADECIMENTOS}

Neste momento, selo o grande percurso que trilhei pela dissertação com este profundo agradecimento a todos os seres que de alguma forma, mesmo que pequenina, contribuíram para a realização deste trabalho.

Inicialmente, agradeço a grande dedicação e sabedoria da minha mãe Lúcia Maria Prado Escobar, pois sem seu amor jamais conseguiria realizar este acontecimento. Ao meu pai Antonio Roberval Miketen e sua belíssima forma de comunicar-se comigo através de seus livros. Também sou muito grata à minha irmã Laura Escobar Maia pelo carinho e os ataques de riso. À minha tão querida vovó Neri Escobar e suas mensagens dos anjos. Ao meu tio José Floriano Prado Escobar que sempre foi exemplo de dedicação aos estudos e à minha tia Mariana Prado Escobar.

Agradeço aos agricultores que, com seus olhos brilhantes, sempre ensinaram-me muito mais do que os escritos através das mãos pintadas de marrom. Principalmente à querida Valéria, Vânia, dona Massui, Tomi, Ana do Mel e seu Zé da Floresta.

Aos amigos de tantos espaços e tempos, que foram muitos e muitos que me ajudaram, assim fazendo o impossível ser possível. O processo foi iniciado com minha turma do PROCAM, grandes agitadores de escritos acadêmicos e festas juninas. Depois amigos do LabCidade (FAU/USP), onde trabalhei no plano de manejo dos Parques Naturais Municipais da zona sul, coordenado pelo Prof. Dr. Euler Sandeville Jr, o qual sou muito grata pelos ensinamentos em espirais. À Gabriella Radoll, Rafael Siqueira, Larissa Nebsnyj, Priscila Ikematsu, Henrique Pozo, Andrea Broering, Melissa Matsunaga, Ciça Angeleli, Lúcia Omar (de Moçambique), Rodrigo Faria, Joyce Reis e Mariana Santos. Grandes amigos da disciplina de Piracicaba ministrada pelo inspirador Prof. Dr. Marcos Sorrentino, das animadas viagens com a Ísis Akemi e risadas sem fim com a Carolina Daher. À talentosa Profa. Dra. Sueli Furlan, à Profa. Dra. Ermínia Maricato e ao Prof. Dr. João Sette Whitaker Ferreira, ao Prof. Dr. Nabil Bonduki, à querida Prof. Dra. Luciana Travassos, à oportunidade de auxiliar nas aulas do prestimoso

Prof. Dr. Diamantino Pereira que abriu espaço à agricultura biodinâmica e à permacultura. Também às amigas de monitoria e debates urbano-rural sem fim: Ana 
Paula Vaidiones e Ivini Ferraz e também ao Joaquim Junior, à Clara Ribacamá e ao Papucides Ntela.

Aos amigos, muitos, que fiz nas APAs Bororé-Colônia e Capivari-Monos, especialmente à equipe da DUC (Divisão Técnica de Unidades de Conservação da Secretaria Muncipal do Verde e do Meio Ambiente) que, além de serem os esteios da minha pesquisa, abriram suas portas para eu colocar em prática a escrita no papel. E hoje, navego por uma incrível experiência ao participar concretamente dos caminhos que tracejam a agricultura no município de São Paulo. Com especial agradecimento à Maria Lúcia Bellenzani que é uma grande estrela guia, à dupla dinâmica Vinicius Martuscelli e Felipe Spina, ao Arpad Spauding que trouxe o grande insight de meu trabalho, ao Túlio do Amaral que é um impecável ser da floresta. Às parcerias da querida Alice Melges, Diego Gonçalves, Leo Malagoli, Janio Rodrigues, Daniel Martins, Vanessa Morimoto, Olga Gross, Clóvis Oliveira, Soraia Ramos, Mariana Belmont, Fernanda Moraes, Oswaldinho Landgraf, Ceceo Chaves, Christiane Costa e André Biazoti. Também aos queridos Luciano de Assis, Débora Gomes, Renan Leme, Juliana Teixeira, Clécia, Liginha, Dilene Chaves, Ricardo Tameirão. E a tantos outros.

Aos amigos-irmãos João de Aquino, Karoline Rempel, Satyavan, João Schnorr, Patrícia Leite, Alexandre Amendola, André Oliveira, Carlos Eduardo de Lucca, Alice Bugarib, André Takarrashi, Mitsuo Shida, Bárbara Bolzani, Gabriela Bitencourt, Carolina Olga, Cesar Negro, Lígia Borges, Ian Sofredini, Jaciara Mariano, Virgínia Liuti, Bruno Padilha, Bruno Cavalcanti, Bruno Ulmann, Beto Lopes. E especialmente ao estimado Prof. Luiz Carlos Beduschi Filho que foi fundamental para a conclusão de meu trabalho. 
A selva é fartura.

(Antônio Roberval Miketen) 


\section{RESUMO}

MIKETEN, Simone. Agricultura e conservação ambiental: o caso da Área de Proteção Ambiental (APA) Bororé-Colônia no município de São Paulo, 2013, $186 f$. Dissertação (Mestrado) - Programa de Pós-Graduação em Ciência Ambiental (PROCAM), Universidade de São Paulo, São Paulo, 2013

A presente pesquisa objetiva contribuir para a reflexão crítica a respeito dos arranjos institucionais que relacionam agricultura e conservação ambiental na porção sul do município de São Paulo, mais precisamente no território da Área de Proteção Ambiental (APA) Bororé-Colônia; assim como a compreensão da perspectiva dos agricultores locais, os quais habitam territórios que mesclam o rural e o urbano. As unidades de produção agrícola localizadas em espaços periurbanos, vêm adquirindo visibilidade frente a necessidade em caráter emergencial da conservação ambiental de áreas abundantes em recursos naturais, principalmente hídricos, para abastecimento da cidade. Contudo, a existência de agricultura para comercialização em áreas de mananciais localizadas no perímetro urbano do município, levanta questões acerca das definições e delimitações de temas como urbano, rural, periurbano e a noção de cidade integrados ao debate acadêmico que vem conceituando o rural e o urbano como temas dicotômicos, além da relação com esfera da administração pública gerando consequências diretas na determinação da cobrança de tributos e atribuição de competências municipais e estaduais. Em resposta a esses questionamentos, emergem novos debates a respeito da agricultura na proximidade de aglomerados urbanos como a valorização da agricultura urbana e periurbana e os crescentes processos de transição agroecológica visando a conservação ambiental nas proximidades de complexos urbanos. Os procedimentos metodológicos pautam-se na pesquisa participante priorizando coleta de dados e observação em campo com gestores públicos e agricultores locais.

Palavras-chave: agricultura urbana e periurbana, agroecologia, conservação ambiental 


\begin{abstract}
MIKETEN, Simone. Agriculture and environmental conservation: the case of Environmental Protect Area Bororé-Colônia on the city of São Paulo, 2013, 186f. Thesis Master's Dissertation - Graduate Program of Environmental Science, Universidade de São Paulo, São Paulo, 2013

This present research intends to contribute for a critical reflection of institutional arrangements related to agriculture and environmental conservation in the south region on the city of São Paulo, most precisely on the Environmental Protection Area BororéColônia territory; as well as the comprehension of local agriculturists perspective, who inhabit areas that mingles rural and urban territories. Agriculture production units located in peri-urban spaces are acquiring visibility in order to fulfil an urgent need of environmental preservation in abundant areas of natural resources, mainly hidric, supplying the city. However, the existence of cultivation for commercialization in fountainhead regions located on the urban perimeter of the county, put a question regarding the definitions and delimitations of topics as urban, rural, peri-urban and even the notion of city integrated to the academic debate that starts bringing the rural and the urban as dichotomous themes, besides the relationship with the public administration sphere, producing direct consequences on the resolution of taxes, tributes and assignment for town and state competence tasks. In order to answer these questions, raising new discussions concerning agriculture farming next to urban agglomerates such as the valorization of urban and peri-urban agriculture and the increasing agroecological transition processes aiming environmental preservation next to the city urban perimeter. The methodological procedures are regulated in this present research through the collection of data and field observation with public supervisors and local agriculturists.
\end{abstract}

Key words: urban and peri-urban agro culture, agroecology, environmental conservation 


\section{LISTA DE SIGLAS}

AAO - Associação de Agricultura Orgânica

ABAST - Supervisão Municipal de Abastecimento

ABD - Associação Biodinâmica

AF - Agricultura não familiar

AOD - Área de Restrição e Ocupação

APA - Área de Proteção Ambiental

APHCE - Associação Holística de C

APP - Área de Preservação Permanente

APRM - Área de Proteção e Recuperação de Mananciais

ARA - Área de Recuperação Ambiental

ARO - Área de Restrição e Ocupação

CADES - Conselho Municipal do Meio Ambiente e Desenvolvimento Sustentável

CATI - Centro Estadual de Assistência Técnica Integral

CBRN - Coordenadoria de Biodiversidade e Recursos Naturais

CEASA - Central de Abastecimento

CNUMAD - Conferência das Nações Unidas sobre Meio Ambiente e o Desenvolvimento

CONAMA - Conselho Nacional de Meio Ambiente

CONFEMA -Conselho do Fundo Especial do Meio Ambiente e Desenvolvimento

Sustentável

CT - Câmara Técnica

DAP - Declaração de Aptidão ao PRONAF

DEPAVE - Departamento de Áreas Verdes

DEPAVE-8 - Divisão Técnica de Unidade de Conservação e Proteção da Biodiversidade

e Herbário

DERSA - Desenvolvimento rodoviário S.A.

DGD - Divisão de Gestão Descentralizada

FAO - Organização das Nações Unidas para a Alimentação e a Agricultura 
FEMA - Fundo Especial de Meio Ambiente e Desenvolvimento Sustentável IBD - Instituto Biodinâmico

IBGE - Instituto Brasileiro de Geografia e Estatística

IBT - Instituto de Botânica

IEA - Instituto de Economia Agrícola

IFOAM - Federação Internacional de Movimentos de Agricultura Orgânica

INCRA - Instituto Nacional de Colonização e Reforma Agrária

IPTU - Imposto Predial e Territorial Urbano

ITCP - Incubadora Tecnológica de Cooperativas Populares

ITR - Imposto Territorial Rural

MDA - Ministério do Desenvolvimento Agrário

MDS - Ministério do Desenvolvimento Social e Combate à Fome

PDE - Plano Diretor Estratégico

PDPA - Plano de Desenvolvimento e Proteção Ambiental

PDRS - Projeto do Desenvolvimento Rural Sustentável

PDR - Planos Diretores Regionais

PESM - Parque Estadual da Serra do Mar

PNDA - Plano Nacional de Defensivos Agrícolas

PNM - Parques Natural Municipal

PRIS - Áreas de Interesse Social

PROAURP - Programa de Agricultura Urbana e Periurbana

PRONAF - Programa Nacional da Agricultura Familiar

RBCV - Reserva da Biosfera do Cinturão Verde

RMSP - Região Metropolitana de São Paulo

RPPN - Reserva do Patrimônio Particular Natural

SAA- Secretaria Estadual da Agricultura e Abastecimento

SABESP - Companhia de Saneamento Básico do Estado de São Paulo

SAN - Segurança Alimentar e Nutricional

SAF - Sistema Agroflorestal

SESAN - Secretaria Nacional de Segurança Alimentar e Nutricional

SMA - Secretaria Estadual do Meio Ambiente 
SMS - Secretaria Municipal da Saúde

SMSP - Secretaria Municipal de Coordenação das Subprefeituras

SNUC - Sistema Nacional de Unidades de Conservação

SVMA - Secretaria Municipal do Verde e do Meio Ambiente

UC - Unidade de Conservação

UBS - Unidade Básica de Saúde

UNESCO - Organização das Nações Unidas para a Educação, a Ciência e a Cultura

UNICAFS - União de Cooperativas de Agricultura Familiar

USP - Universidade de São Paulo

UTM - Sistema Universal Transverso do Mercador

VBP - Valor Bruto de Produção

ZEE - Zoneamento Ecológico Econômico

ZEPAG - Zona Especial de Produção Agrícola e Extração Mineral

Z8-100 - Zona Especial de Uso Rural do Município

ZPDS - Zona de Proteção e Desenvolvimento Sustentável

ZUA - Zona de Uso Agrícola 


\section{LISTA DE MAPAS}

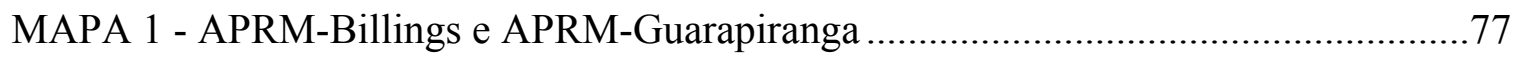

MAPA 2 - UCs municipais na zona sul do município de São Paulo............................................... 83

MAPA 3 - APAs Bororé-Colônia e Capivari-Monos .......................................................92

MAPA 4 - Divisão das Subprefeituras do município de São Paulo .................................96

MAPA 5 - Unidades de produção agrícola, ZEPAGs e ZUAs ......................................109

MAPA 6 - Unidades de produção agrícola e ZEPAGs na APA Bororé-Colônia...........................132 


\section{SUMÁRIO}

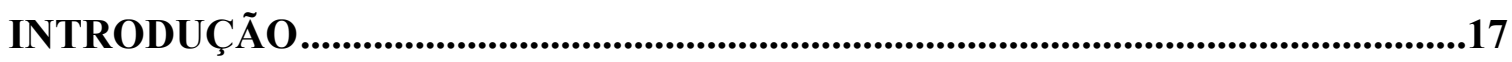

Capítulo 1 - A PERMEABILIDADE DAS NOÇÕES .................................................30

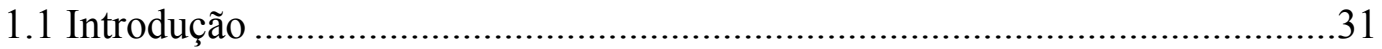

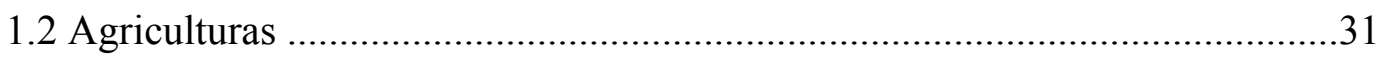

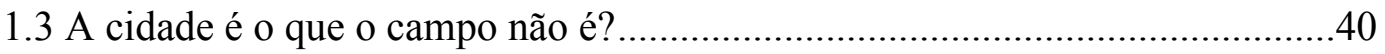

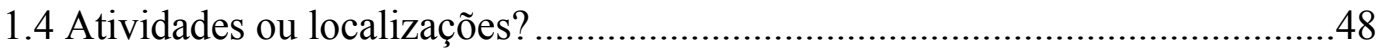

1.5 Agroecologia e multifuncionalidade da agricultura ...................................51

1.6 Agroecologia e multifuncionalidade da agricultura ......................................53

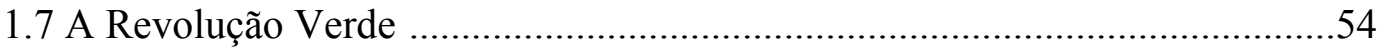

1.8 A Revolução Silenciosa .........................................................................57

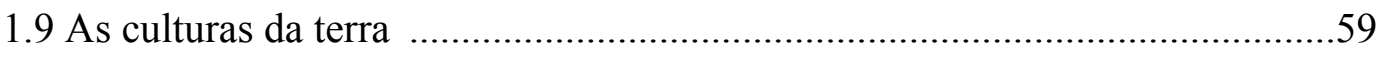

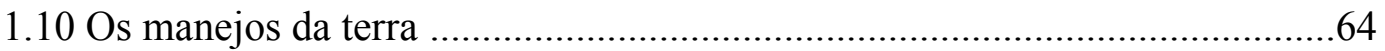

Capítulo 2 - O CAMPO CITADINO ...............................................................65

2.1 Os traços primevos da porção sul paulistana ................................................66

2.2 Santo Amaro, padroeiro dos agricultores.................................................69

2.3 Os trilhos da urbanização ...................................................................... 71

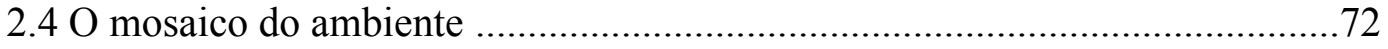

2.4.1 APRMs - Áreas de Proteção e Recuperação de Mananciais ........................73

2.4.2 RBCV - Reserva da Biosfera do Cinturão Verde .......................................78

2.4.3 UCs - Unidades de Conservação................................................................82

2.4.4 PNMs - Parques Naturais Municipais Bororé, Varginha, Itaim, Jaceguava e

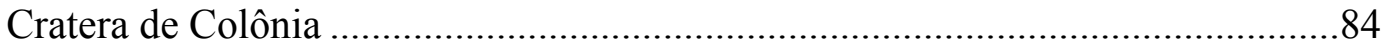

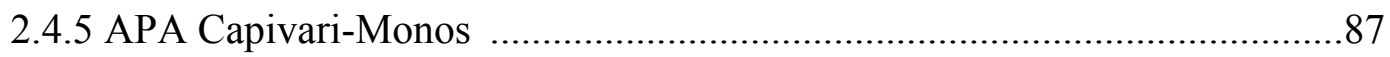

2.4.6 APA Bororé-Colônia - área de estudos ...................................................93

2.5 Marcos regulatórios da agricultura na área de estudos ...............................101 


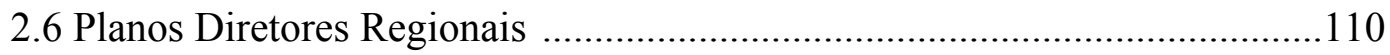

2.7 Agricultura e Legislação Municipal ...............................................................111

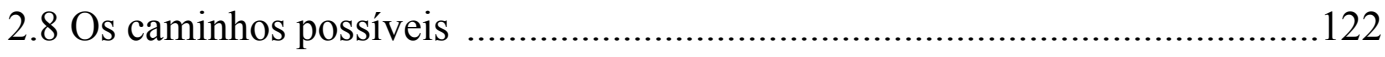

Capítulo 3 - AS CULTURAS DA TERRA ........................................................125

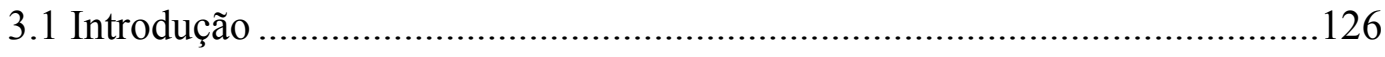

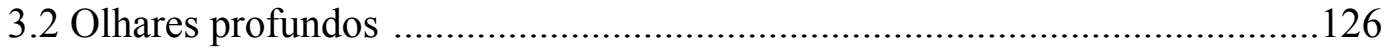

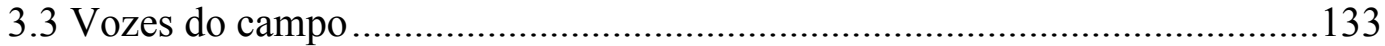

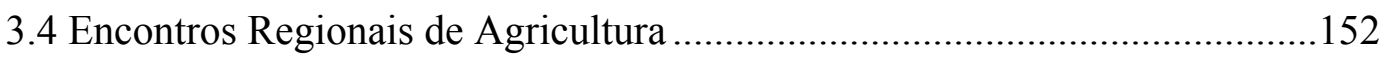

CONSIDERAÇÕES FINAIS ........................................................................................157

REFERÊNCIAS BIBLIOGRÁFICAS ................................................................162 


\section{INTRODUÇÃO}

A porção sul do município de São Paulo reserva um dos mais preservados cenários naturais dentro dos limites administrativos paulistanos. Ao trilhar suas veredas é possível encontrar grandes fragmentos de floresta com mais de setecentas espécies vegetais como bromélias (Billbergia pyramidalis) multicolores, a orquídea terrestre (Zygopetalum pedicellatum), o cambuci (Campomanesia phaea) à exemplo das frutíferas nativas, a samabaiaçu (Cyathea glaziovii), o cedro-rosa (Cedrela odorata), o palmitojuçara (Euterpe edulis), a embaúba (Cecropia juranyiana) entre outros; vivificados por uma grande variedade de fauna com mais de trezentas espécies de animais que se fazem perceber por meio do ronco forte do macaco bugio-ruivo (Alouatta clamitans), o cachorro-do-mato (Cerdocyon thous), o colorido do tucano-de-bico-verde (Ramphastos dicolorus), da presença registrada por imagem da onça-parda (Puma concolor capricornensis), do gato-do-mato (Leopardus tigrinus), o gavião pega-macaco (Spizaetus tyrannus), o cachorro-do-mato (Tapirus terrestris), a jaguatirica (Leopardus pardalis mitis), as jararacas (Bothrops jararaca) e o coaxar de anfíbios da Ordem Anura no coro de sapos e pererecas (SÃO PAULO, 2001, p. 74). Outra riqueza que verte em abundância do solo é o elemento água desenhando rios cristalinos em áreas de mananciais com significativas nascentes e várzeas ao exemplo ilustrado abaixo do rio Embu-Guaçú.

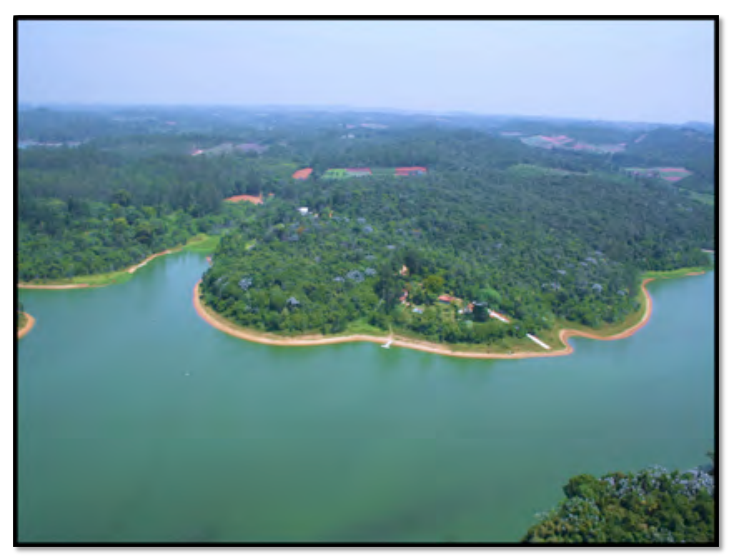

FIGURA 1: Represa Billings - Península do Bororé

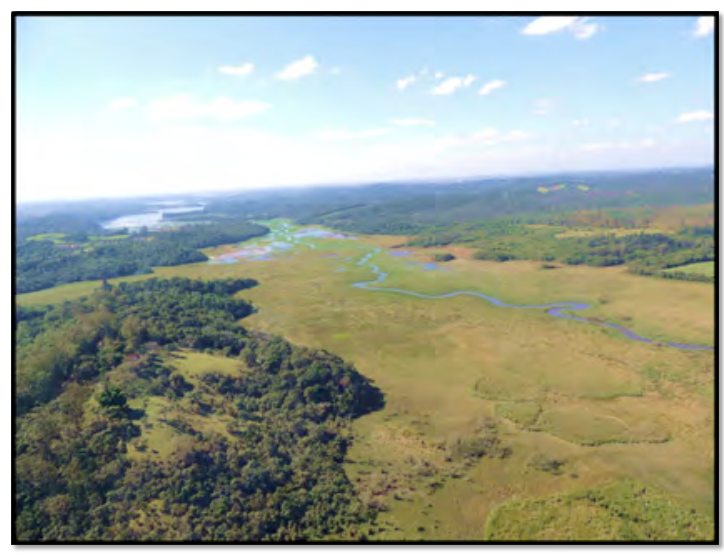

FIGURA 2: Represa Guarapiranga - Várzea rio Embu-Guaçú REGISTRO FOTOGRÁFICO: Simone Miketen - outubro 2012

Esta natureza não permanece intocada, pois sua paisagem natural também é esculpida pelo ser humano através dos desenhos agrícolas de centenas de unidades de 
produção situadas na localidade, além de áreas protegidas normatizadas como Unidades de Conservação de diferentes categorias, e da presença indígena nas duas aldeias do tronco Guarani.

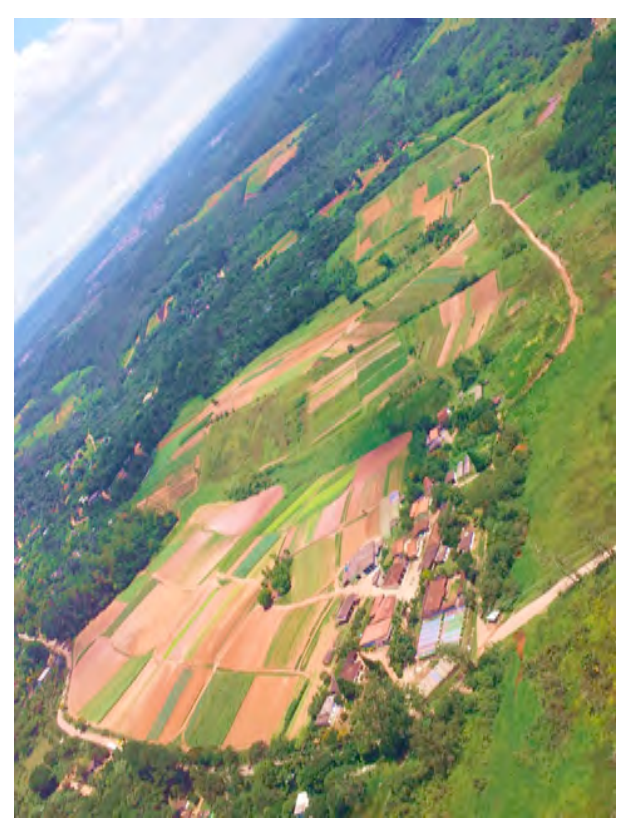

FIGURA 3 - Agricultura Parelheiros REGISTRO: Simone Miketen (outubro 2012)
Contudo, estas áreas de mananciais e as unidades de produção agrícola estão situadas dentro do perímetro urbano do município de São Paulo, o mesmo que comporta, em suas áreas mais centrais, o maior aglomerado urbano do país. Decodificado em números, os limites administrativos paulistanos têm a extensão territorial de $1,521,101 \mathrm{~km}^{2}$, os quais abrigam 11,253,503 habitantes (IBGE, 2010). Com efeito, o gigantesco adensamento citadino forma uma enorme mancha urbana que extrapola o perímetro municipal de São Paulo e consolida-se em escala metropolitana, assim formando um das maiores manchas urbanas do

planeta. Entretanto, ao trilhar os caminhos demarcados por antigos indígenas, partindo do centro principal da capital em direção sul à escarpa da Serra do Mar, é possível identificar um gradiente de urbanização que se concentra na área central e vai diminuindo a densidade até configurar uma paisagem predominantemente natural e rural no extremo sul do município.

Porém, as áreas de mananciais paulistanas estão ameaçadas pela crescente urbanização, a qual vem ocorrendo continuamente de forma irregular e gera impactos refletidos na degradação ambiental destas áreas. Esta dinâmica é resultado da constante busca por terras urbanizáveis e por espaços de moradia que vem sendo protagonizada por diversos atores sociais de camadas de baixa e alta renda, pelo mercado imobiliário, além do próprio poder municipal. Entretanto, estas áreas ricas em biodiversidade resguardam elementos vitais, principalmente recursos hídricos, que abastecem e são responsáveis pela 
qualidade ambiental da própria cidade. Como consequência, este fenômeno anuncia a necessidade de revisão e reflexão crítica acerca do planejamento e da gestão pública em relação ao uso e ocupação da terra no limite municipal.

A cadência desta contradição cria espaços que preservam características rurais e sofrem influência direta do intenso processo de urbanização irradiado da cidade, formando pequenas áreas urbanizadas entrelaçadas a um cenário típico do campo. Neste contexto, a emergência de questões ambientais e a preocupação com a qualidade das águas da vasta área de mananciais, levou o poder público a criar uma série de legislações ambientais, tendo como diretriz a restrição da ocupação antrópica destes espaços. A partir dos anos 1970

e, principalmente, na

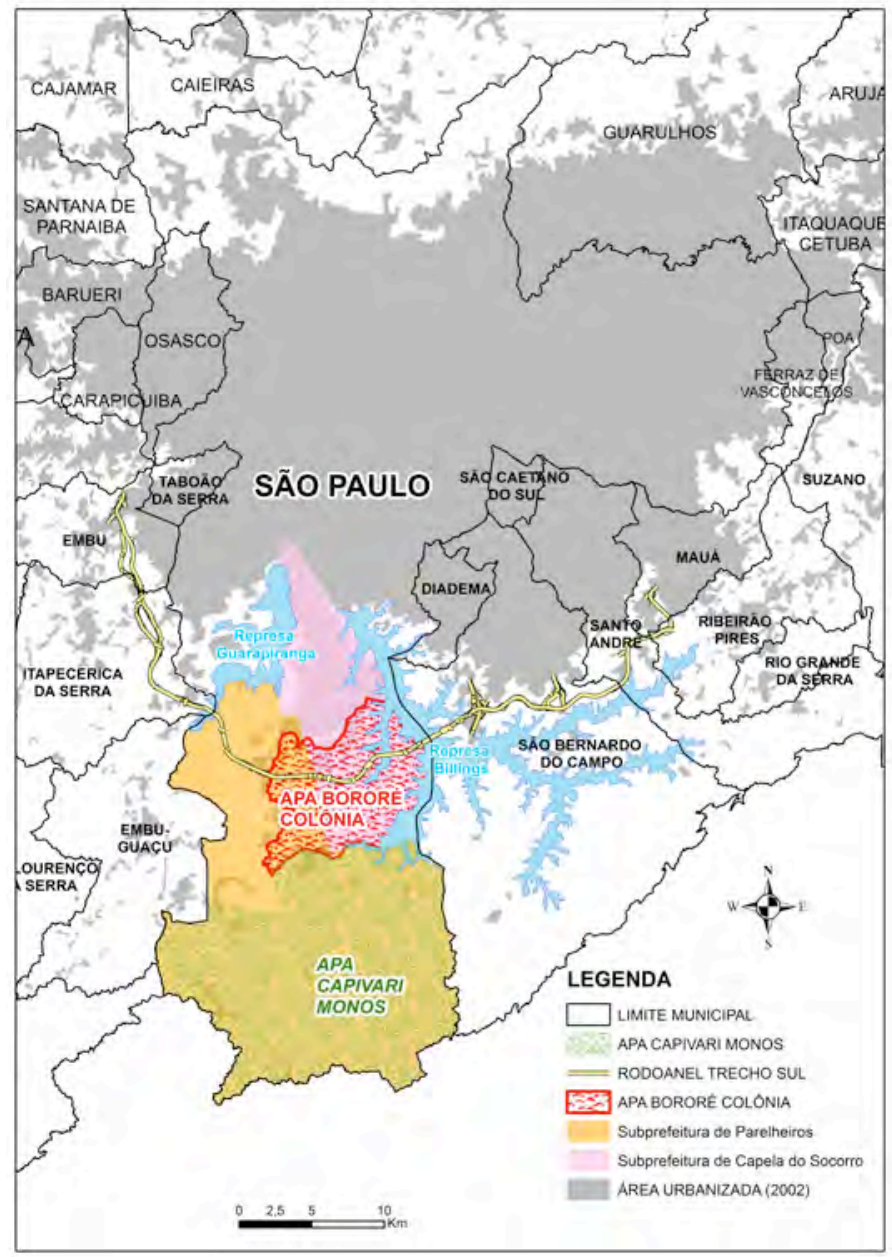

FIGURA 4: Mancha urbana consolidada ORGANIZAÇÃO: Priscila Ikematsu

primeira década dos anos 2000, uma série de normatizações criaram unidades de gestão e planejamento ambiental, como exemplo, a criação das Áreas de Proteção Ambiental (APAs) Bororé-Colônia e Capivari-Monos que buscam salvaguardar áreas de preservação ambiental ricas em biodiversidade e recursos hídricos.

$\mathrm{Na}$ composição desta heterogeneidade espacial existe um significativo número de unidades de produção agrícola que vem ganhando a atenção do poder público por meio da criação de uma série de instrumentos normativos ambientais que ressaltam a agricultura, orientada no sentido dos princípios e práticas da agroecologia, como um tipo 
de uso da terra com potencial de preservação dos recursos naturais, principalmente hídricos, e contenção da expansão urbana. A presente dissertação tem como objetivo compreender a relevância da atividade agrícola pelo enfoque da conservação ambiental na zona sul do município de São Paulo, onde ocorre a dinâmica de um encontro de realidades: o rural e o urbano, cuja representação tem maior intensidade no território da Área de Proteção Ambiental (APA) Bororé-Colônia, a qual foi estabelecida como área de estudo. Investigar os arranjos institucionais responsáveis pela formulação e execução destas políticas públicas voltadas para a promoção da agricultura e da conservação ambiental, assim como ações e instrumentos de operacionalização configura o primeiro objetivo específico do presente trabalho.

Contudo, a imagem deste encontro rural-urbano não se traduz por um princípio de oposição, mas sim identifica a permeabilidade das noções de urbano e rural. Compreendidas de forma reflexiva, estas noções mesclam-se em um universo de elementos sobrepostos e interrelacionados que são frutos do campo e frutos da cidade. Este cenário, contudo, é dinamizado por atores locais que interferem na construção da realidade criando experiências cotidianas sejam físicas, culturais, institucionais ou mesmo simbólicas. O segundo objetivo específico da dissertação pretende estabelecer uma compreensão em relação à perspectiva dos agricultores locais diante de interesses comuns e conflitantes na relação entre o manejo agrícola e a conservação ambiental.

O capítulo que abre o presente trabalho, cunhado 'A permeabilidade das noções', disserta a respeito da relação intrínseca entre a atividade agrícola e o ambiente através do desenvolvimento teórico de noções emergentes na área de estudos. Neste sentido, aspectos dicotômicos que definem localizações rurais e urbanas ganham novos sentidos quando estabelecidos em espaços periurbanos, como no caso da APA Bororé-Colônia, que conjugam diversos tipos de uso e ocupação da terra. Esta configuração territorial apresenta uma grande permeabilidade entre as diversas noções, sendo um espaço promissor para inovações como a multifuncionalidade da agricultura, o fortalecimento do manejo agroecológico e o surgimento da agricultura urbana e periurbana.

O segundo capítulo 'O campo citadino' apresenta o histórico de uso e ocupação da APA Bororé-Colônia que, localizada à margem da mancha urbana consolidada, sofre forte pressão da expansão urbana configurando dentro de seu perímetro um tecido urbano 
composto de moradias precárias, altos índices de vulnerabilidade social e concentração populacional; conjugada à áreas verdes ricas em biodiversidade, remanescentes de Mata Atlântica, cabeceiras de grandes reservatórios de água, sendo importante área de mananciais e bacias hidrográficas. A área de estudos apresenta um grande número de agricultores familiares que encontram dificuldades em receber benefícios públicos por conta da falta de regularização fundiária e por sua localização pouco clara no perímetro urbano. Isto ocorreu porque o instrumento de planejamento e gestão do município de São Paulo, o Plano Diretor Municipal Estratégico, delimitou o perímetro urbano e zonas especial de proteção ambiental, relegando à agricultura algumas Zonas Especiais de Agricultura e Extração Mineral (ZEPAG) sem um mapeamento real e acompanhamento desta atividade. Entretanto, um Programa de Agricultura Urbana e Periurbana (PROAURP); ações da Secretaria Municipal do Verde e Meio Ambiente (SVMA) por meio de subsídios para a agroecologia e a Câmara Técnica conjunta de Agricultura e Desenvolvimento Rural Sustentável das APAs Capivari-Monos e Bororé-Colônia; um selo de procedência agroambiental (Protocolo Guarapiranga); além da criação de três Casas da Agricultura Ecológica foram concebidos objetivando a valorização da atividade agrícola que sobrevive sob pressão de um dos maiores aglomerados urbanos do planeta.

O terceiro e último capítulo 'As culturas da terra' traz para a presente investigação científica o levantamento das visões dos agricultores locais a respeito do ambiente onde estão inseridos, do tipo de manejo realizado e da maneira que o poder público vem fortalecendo o processo de transição agroecológica. Neste sentido, a interpretação e análise de dados primários e secundários foram realizadas com base no universo amostral de produtores contemplados e não contemplados com os diversos programas públicos em andamento, os quais vem fomentando o processo de transição agroecológico no extremo sul do Município paulistano.

\section{PROCEDIMENTOS METODOLÓGICOS}

A grande complexidade da área de estudos apresenta uma gama de elementos socioespaciais que contribui para encaminhar a investigação na direção da pergunta inicial que emergiu da seguinte forma: por que a atividade agrícola dentro da porção sul 
do limite municipal de São Paulo está adquirindo importância no cenário de políticas públicas, visto que o município apresenta a maior aglomeração urbana do país? Este questionamento serviu de esteio para a estrutura do trabalho, pois a investigação científica de uma realidade, sobretudo em pesquisas de caráter social, pode ter como ferramenta inicial a formulação de uma pergunta, a qual explicita a composição do problema científico fundamental da pesquisa, assim como sua relevância científica. As visitas de caráter explaratório à área de estudos contribuíram para desenhar a hipótese que serve de base para o debate conceitual, sendo:

O alto impacto da expansão urbana, refletido na degradação de áreas de manaciais na porção sul do município de São Paulo, gerou uma série de problemas ambientais que causaram riscos ao provimento de recursos hídricos e naturais para áreas centrais do município. A agricultura, especialmente orientada no sentido do manejo agroecológico, vem sendo valorizada na agenda das políticas públicas enquanto instrumento potencial para conservação ambiental e contensão da expansão urbana nas áreas de manaciais, visto que ocupa espaços de forma a preservar a qualidade ambiental e proteger a paisagem natural.

É necessário destacar que a hipótese é uma chave de entendimento, a qual Thiollent denomina como diretriz qualitativa criada a priori que organiza o raciocínio teórico. A lógica hipotética de uma pesquisa científica pode ser comprovada ou até mesmo refurtada a partir do envolvimento com o objeto de estudo, por meio de levantamento de dados e construções de argumentações (THIOLLENT, 2009, p. 36). sendo, assim, analisada a partir de procedimentos qualitativos apoiados em métodos científicos da pesquisa social. Existem diversas conceituações de 'pesquisa social', porém, na presente investigação pode ser definida como um processo que utiliza métodos científicos para a compreensão de fenômenos no campo da realidade social (GIL, 2004, p. 26). O termo 'qualitativo' refere-se à tipologia de análise dos dados levantados a respeito da área de estudo, sejam através de entrevistas e observações de campo ou mesmo análise de documentos, que tem como unidade de interpretação a qualidade dos temas que emergem, sendo denominados como 'indicadores'. A pesquisa quantitativa tem como foco de análise os 'índices', ou seja, os números gerados a partir da quantificação da frequência dos 'indicarores' (BARDIN, 1973, p. 49). Em certos 
momentos, os indicadores serão utilizados na presente pesquisa como ferramentas de argumentação para conclusões qualitativas.

A investigação parte do princípio que a interpretação da realidade local pauta-se na análise qualitativa baseada em visitas de campo e entrevistas com o mínimo possível de protocolos de campo, ainda que existentes, para abrir espaço ao diálogo entre o pesquisador e os atores locais. Para tocar o mundo das subjetividades, cabe ao pesquisador vivenciar o cotidiano e mergulhar nas representações dos indivíduos e instituições que constroem e compartilham aquele território, tendo um efeito de existência e experiência através da interação com aquele mundo. A postura da presente pesquisadora procura estabelecer uma comunicação dialógica a frente as pessoas e grupos que vivenciam de diversificadas maneiras a realidade do objeto de pesquisa e da área de estudo, seja no plano físico dos desenhos da lavoura, tanto quanto no discurso de agricultores, órgãos públicos e organizações não governamentais (ONGs) em relação à bandeira da conservação ambiental.

A natureza desse diálogo pode ser concebida por meio das palavras de David Bohm (1989) que sugere a imagem de fluxos de significados compartilhado entre os intelecutores para emergir uma nova compreensão do tema abordado. Para Paulo Freire 1996, p. 51), dialogar requer uma abertura ao mundo e aos outros que pode ser compreendida como: "a disponibilidade curiosa da vida (...) é o objeto de reflexão crítica (...) a boniteza que há nela como viabilidade do diálogo (...) experiência fundante do ser inacabado (...) inconclusão em permanente movimento da História”. Com efeito, a prática de abrir espaços para o agente vivente daquela realidade transmitir sua própria compreensão da realidade em que está inserido, traz um material primário bruto cheio de riquezas para ser lapidado a partir de transcrições e criação de unidades de análise.

Cabe ressaltar que o pensamento reflexivo acerca do método, mesmo com liberdade de proposições, compreende algumas diretrizes epistemológicas, sendo o termo 'metodologia' compreendido como o estudo crítico dos métodos que conduzem a pesquisa científica, estabelecida em um 'metanível' (THIOLLENT, 2009, p. 27), ou seja, na reflexão da reflexão. Por este motivo, é possível afirmar que existe uma função pedagógica para o pesquisador, "isto é, a formação do estado de espírito e dos hábitos correspondentes ao ideal da pesquisa científica" (THIOLLENT, 2009, p. 28). A 
investigação qualitativa de objetos complexos trouxe como ponto de inflexão a própria postura do pesquisador, a qual muitas vezes não se torna evidente apenas no resultado apresentado e sim na relação com o próprio processo da pesquisa científica.

Contudo, a investigação parte de procedimentos de campo objetivando o levantamento de argumentações e resultados de pesquisa por meio de protocolos ou procedimentos técnicos que consistem em: levantamentos na área de estudo de material bibliográfico e estudos acadêmicos; busca por legislações principalmente municipais que parametrizam a agricultura e a conservação ambiental, assim como programas públicos realizados ou em andamento; entrevistas com gestores públicos e demais atores que fomentaram as normas institucionais; acompanhamento dos mesmos em vistorias e capacitações; visitas as propriedades agrícolas para acompanhar o cotidiano dos agricultores locais, assim como reuniões e cursos em geral.

\section{LEVANTAMENTO DE OLHARES INSTITUCIONAIS}

A aproximação com os atores locais foi estabelecida na fase de campo exploratório através da presença da presente pesquisadora em reuniões mensais do Conselho Gestor das APA Bororé-Colônia, tendo o objetivo de identificar como os temas agricultura e conservação ambiental eram articulados na área de estudos pelo poder público e organizações locais. De acordo com Gil (2004, p. 101) os procedimentos de campo neste momento exploratório assemelharam-se com a chamada 'observação simples' em que: o grau de participação do pesquisador é de expectador e não há planejamento estruturado, mas sim o intuito de levantar elementos para definir o problema e a hipótese; identificar os atores locais, o cenário e as relações sociais; registrar apreensões no diário de campo (GIL, 2004, p. 101). Como resultados de pesquisa podemos elencar: a aproximação com os gestores públicos e ONGs que atuam na área; entendimento de ações e programas públicos relacionados a agricultura e conservação ambiental; aproximação com moradores locais, especialmente, agricultores.

Iniciado a fase de campo exploratória, foram elencadas as legislações ambientais e programas, a fim de averiguar as ações públicas que tinham interface entre a agricultura e a conservação ambiental e realizar a análise documental do material selecionado. $\mathrm{O}$ 
Programa de Agricultura Urbana e Periurbana (PROAURP) do município de São Paulo, criado em 2004, foi configurado como um marco legal importante por conta da sua importância no Plano Diretor Municipal, do subsídio à criação da Casa de Agricultura Ecológica e da série de projetos de transição agroecológica fomentados pela Secretaria Municipal do Verde e do Meio ambiente (SVMA). Por meio da leitura da legislação, programas e compilação dos textos foi desenvolvida a análise documental que, de acordo com Bardin (1973, p. 51) configura um conjunto de operações que transformam uma fonte primária de documentação em um segundo documento interpretativo do primeiro, com o objetivo de disponibilizar as informações da base de dados de uma forma diferente para uma consulta mais facilitada. Os resultados da pesquisa documental podem ser representados no quadro abaixo:

POLÍTICAS PÚBLICAS - AGRICULTURA E CONSERVAÇÃO AMBIENTAL

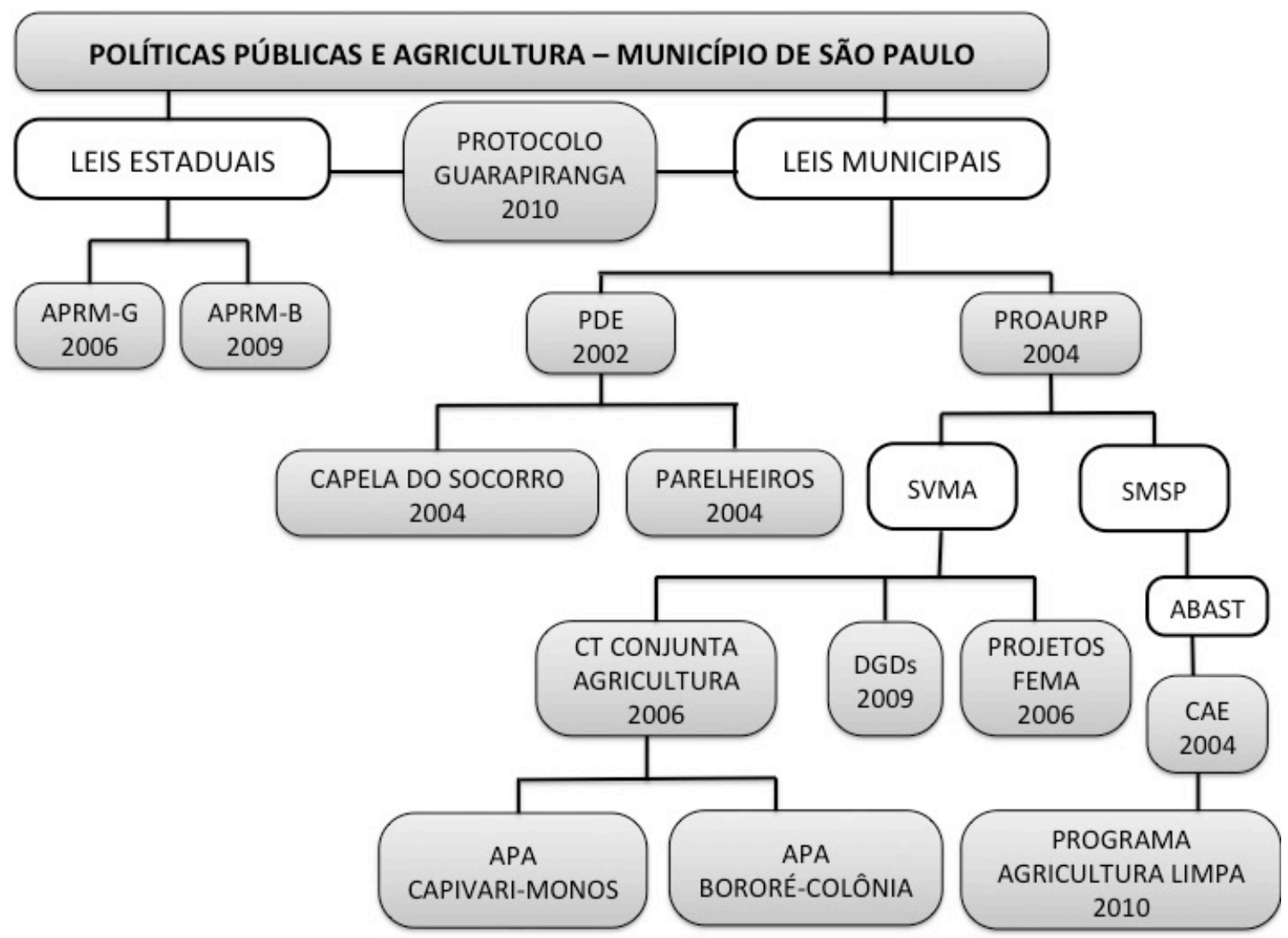

FIGURA 5: Políticas públicas: agricultura conservação ambiental ORGANIZADORA: Simone Miketen 
O quadro acima tem por objetivo apresentar uma organização lógica da complexidade de arranjos públicos ${ }^{1}$ que relacionam agricultura e conservação ambiental, e incidem de forma ativa na área de estudos. Inicialmente foram separadas as Leis Estaduais e as Leis Municipais, tendo uma Resolução Conjunta (Protocolo Guarapiranga) que se encontra entre as duas categorias. O destaque entre às Leis Estaduais foi encontrado nas Leis Específicas das APRMs das represas Guarapiranga e Billings.

A legislação municipal foi dividida entre ações do Plano Diretor Estratégico (PDE), ações da Secretaria do Verde e do Meio Ambiente (SVMA) e ações da Secretaria da Coordenação das Subprefeituras (SMSP). Ao PDE foram incorporados os Planos Diretores Regionais de Parelheiros e Capela do Socorro. À SMVA foi incorporada a Câmara Técnica conjunta de Agricultura e Desenvolvimento Rural Sustentável dos Conselhos Gestores das APAs Capivari-Monos e Bororé-Colônia, o Fundo Especial de Meio Ambiente e Desenvolvimento Sustentável (FEMA), o Departamento de Gestão Descentralizada (DGD) pelas atribuições que constam no Programa de Agricultura Urbana e Periurbana (PROAURP). A SMSP tem destaque por conta da Supervisão Geral de Abastecimento (ABAST) que coordena a Casa de Agricultura Ecológica (CAE), o PROAURP em conjunto com a SVMA e outras Secretarias Municipais menos atuantes, e o Programa de Agricultura Limpa que organiza feiras orgânicas com os produtores locais.

Posteriormente ao levantamento do material da área de estudos e bibliografia sobre os temas, as constantes visitas à campo começaram a ter formas mais delimitadas e espaços determinados. Um plano de observação foi traçado sendo organizado da seguinte forma:

\footnotetext{
${ }^{1}$ É possível existir outras normatizações legais que não foram identificadas pela pesquisa.
} 
VISITAS DE CAMPO

\section{REUNIÕES CONSELHO GESTOR DA APA BORORÉ-COLÔNIA}

Acompanhamento de reuniões

Avaliação de atas da Câmara Técnica de Agricultura nos anos de 2011 e 2012

\section{ENCONTROS E MUTIRÕES DOS PROJETOS PÚBLICOS}

Acompanhamento mutirões agroecológicos

Visitas pelas propriedades agrícolas com os servidores púbicos da Casa de Agricultura Ecológica

\section{ENCONTROS E MUTIRÕES DOS PROJETOS DE ONGS}

Acompanhamento de capacitações - Associação Biodinâmica

Acompanhamento de capacitações - Instituto Pedro Mataj

FIGURA 6: Visitas de campo

ORGANIZAÇÃO: Simone Miketen

Concomitantemente ocorreram as seguintes visitas de campo e a coleta de dados:

\section{COLETA DE DADOS SECUNDÁRIOS}

legislação municipal e programas públicos - agricultura relacionado a temas

(1) conservação ambiental

(2) agroecologia

(3) agricultura urbana e periurbana

exceções relevantes

(1) legislação estadual mananciais

(2) legislação e programas públicos intersetoriais

FIGURA 7: Coleta de dados secundários

ORGANIZAÇÃO: Simone Miketen 
A coleta de dados secundários foi realizada nas seguintes instâncias públicas:

\section{FONTES DE DADOS}

SVMA - Secretaria Municipal do Verde e Meio Ambiente

DEPAVE-8 - Divisão Técnica de Unidades de Conservação e Proteção da Biodiversidade e Herbário

Dados fornecidos:

- Conselhor Gestor APA Bororé-Colônia

- COOPERAPAS

DPP - Departamento de Participação e Fomento a Políticas Públicas

Dados fornecidos:

- Projetos do Fundo Especial de Meio Ambiente (FEMA) - Editais de Agricultura

\section{SMSP - Secretaria Municipal de Coordenação das Subprefeituras}

ABAST - Supervisão de Abastecimento / Casa da Agricultura Ecológica de Parelheiros

Dados fornecidos:

- Mapeamento das Unidades de Produção Agrícola - zona sul do município

- Protocolo Guarapiranga - Protocolo de Boas Práticas Agroambientais

\section{SMA - Secretaria Estadual do Meio Ambiente}

CBRN - Coordenadoria de Biodiversidade e Recursos Naturais

Dados fornecidos:

- Protocolo Guarapiranga - Protocolo de Boas Práticas Agroambientais

FIGURA 8: Coleta de dados secundários

ORGANIZAÇÃO: Simone Miketen

Uma série de entrevistas foi realizada com gestores públicos e de ONGs que atuam na região. A entrevista é uma técnica na qual o pesquisador interage com o ator local por meio de questões guiadas a partir dos temas escolhidos (GIL, 2004, p. 109). Para o autor existem diferentes maneiras ${ }^{2}$ de organizar uma entrevista: informal,

\footnotetext{
${ }^{2}$ De acordo com Gil (2004 p. 111) as definições das tipologias de entrevistas são: as informais são as menos estruturadas e só diferencia-se de uma conversa porque tem o intuito de coletar dados; as estruturadas que são baseadas em perguntas fechadas sendo úteis para análises estatísticas; e o grupo focal consiste na reunião de um grupo com o objetivo de responder uma questão genérica que pode ser aprofundada pelo moderador.
} 
focalizada, por pautas, estruturada e grupo focal. As pesquisas realizadas com estes perfis de atores descritos acima variaram entre o tipo (a) focalizada, ou seja, a entrevista realizada de forma não estruturada em que o entrevistado tem um tema e dissertava livremente a respeito e, dependendo da situação, a entrevista era organizada (b) por pautas, com poucas perguntas diretas, uma apresentação de pontos de interesse e fala livre (GIL, 2004, p.111). As entrevistas com técnicos estão organizados abaixo:

\section{ENTREVISTAS TÉCNICOS}

\begin{tabular}{ll}
\hline Maria Lúcia Bellenzani & Agrônoma SVMA \\
jul/11 & Responsável pelo Plano Diretor Regional Parelheiros \\
\hline Felipe Spina Avino & Biólogo SVMA \\
set/11 & Gestor APA Bororé-Colônia \\
\hline Cristiano Mendes & Agrônomo ABAST \\
set/11 & Diretor Casa da Agricultura Ecológica Parelheiros \\
\hline Arpad Spauding & Geógrafo \\
out/11 & Gestor de dois projetos FEMA \\
\hline Nadiella Monteiro & Veterinária ABAST \\
nov/11 & Coordenadora ABAST \\
Nabil Bonduki & Arquiteto \\
ago/12 & Responsável pelo Plano Diretor Estratégico \\
Araci Oyama e Wilson Tivelli & Bióloga SMA e Agrônomo SAA \\
out/12 & Coordenadores Protocolo Guarapiranga \\
\hline Bruno Cavalcanti & Geógrafo \\
nov/12 & Gestor de projetos FEMA e CNPQ \\
\hline
\end{tabular}

FIGURA 9: Entrevista técnicos

ORGANIZADORA: Simone Miketen

As figuras acima ilustram o processo de investigação e de análise do arranjo institucional público referentes à agricultura e à conservação ambiental. O cotidiano dos agricultores da área de estudo também fazem parte da presente investigação científica através dos seguintes procedimentos metodológicos: coleta de dados, entrevistas focalizadas e por pautas, e observação participante em visitas de campo às suas propriedades. As análises e resultados desta etapa da pesquisa estão organizados no terceiro capítulo. 


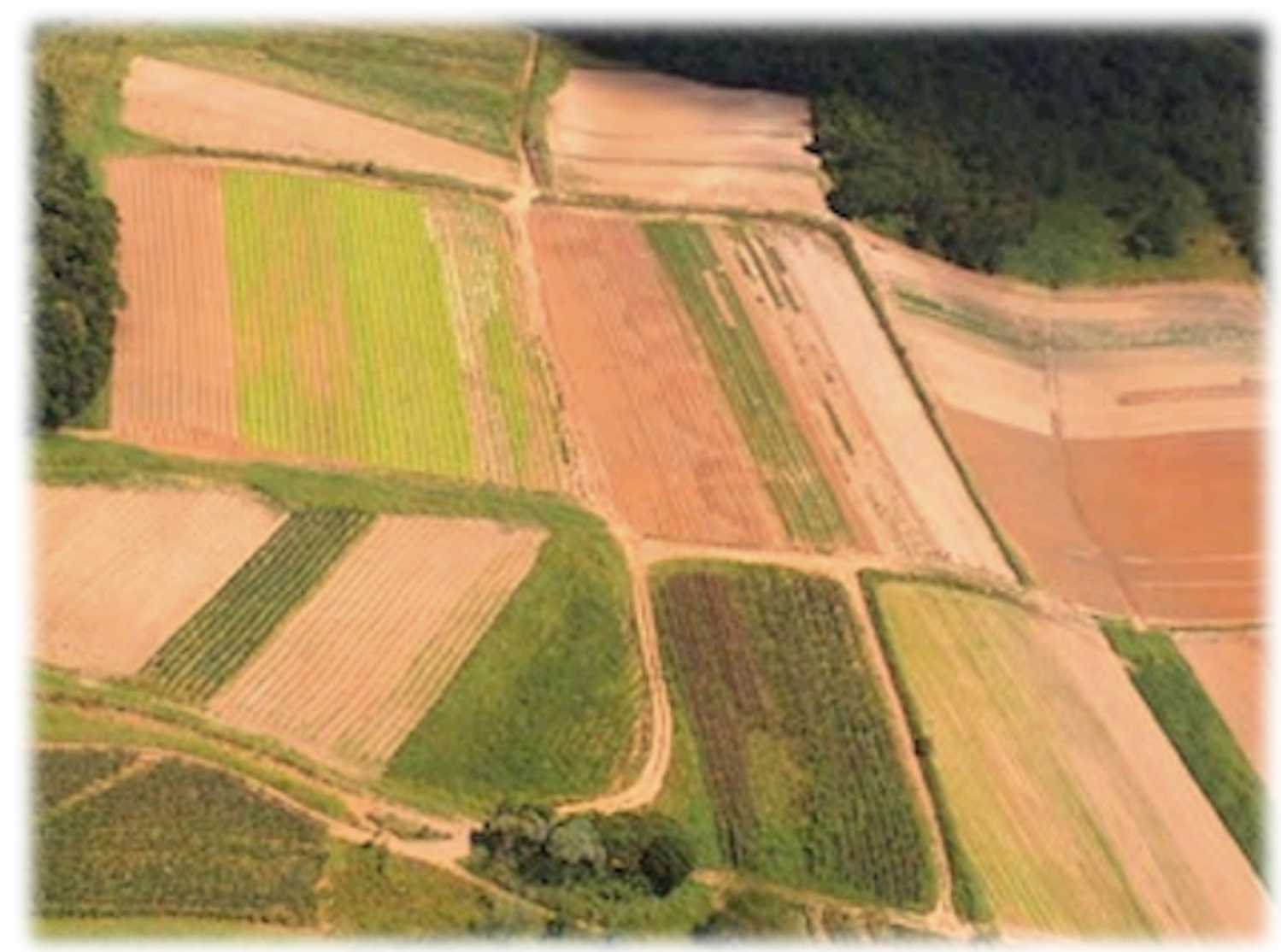

capítulo 1 - A PERMEABILIDADE DAS NOÇÕES 


\subsection{INTRODUÇÃO}

O contexto agrícola na porção sul do município de São Paulo está entremeado em uma série de noções e conceitos gerando um objeto de pesquisa extremamente complexo, principalmente, pelo fato de existirem atividades agrícolas de base familiar aparentemente típicas do espaço rural em espaços tão próximos ao aglomerado urbano. A ideia de agricultura no espaço urbano e periurbano, mesmo sendo um tipo de atividade que sempre existiu, vem ganhando notoriedade nas últimas décadas especialmente pela sua multifuncionalidade que, além de cumprir sua função de abastecimento alimentar, tornar-se um instrumento de conservação ambiental, sobretudo, se manejada de acordo com os princípios da agroecologia. Esta agricultura ainda vem sendo concebida no debate acadêmico atual e cada vez mais está sendo legitimada na agenda da administração pública. Como todo tema emergente, muitos estudos apresentam uma série de contradições e sentidos a respeito da conceituação da própria agricultura em relação ao espaço que ocupa (seja rural, urbano ou periurbano), ao tipo de sistema de manejo (industrial, familiar, agroecológico), além das consequências geradas nas diversas esferas sociais, econômicas, ambientais e culturais dos atores envolvidos. O presente capítulo apresenta o aprofundamento teórico destas diversas noções, permeáveis entre si, tendo como ponto de partida a compreensão da própria agricultura enquanto cultura da terra e a dinâmica de seu ambiente.

\subsection{AGRICULTURAS}

As origens da agricultura estão enleadas na própria história das organizações sociais humanas, pois a medida que o ser humano alterou ecossistemas naturais originais, através da domesticação de espécies, transformou por si mesmo a própria natureza de sua dinâmica social. As primeiras semeaduras da revolução agrícola neolítica ${ }^{3}$ fizeram emergir povos cultivadores (MAZOYER, 1997, p. 70), traduzindo a cultura da terra na imagem de manifestações culturais em interação com sistemas biológicos (CAPORAL, 2006, p. 14). A agricultura per si é um tipo de atividade que evidencia a relação humano-

\footnotetext{
3 (10 mil a.C.)
} 
natureza, sendo que o manejo antrópico, em diferentes níveis e ao mesmo tempo, manipula e obedece o ritmo natural da produção.

Originalmente a agricultura é uma atividade econômica associada ao campo. As áreas rurais são tradicionalmente caracterizadas por povoados isolados, pouco adensados e desprovidos de infraestrutura urbana, tendo uma vasta disponibilidade de terras em meio a paisagens predominantemente naturais. Seu cotidiano é marcado pelos ritmos naturais e a lógica do trabalho obedece às necessidades do núcleo familiar, além de formas de sociabilidade baseadas em laços vicinais dinamizados pelo sistema de mutirões. Muitos elementos culturais semelhantes são encontrados no povoado como as práticas festivas, a própria organização familiar, os eventos religiosos sediados na igreja local e, até mesmo, modelos similares de técnicas de manejo da terra e seus ferramentais (CÂNDIDO, 1964, p. 108).

Estas características do mundo rural brasileiro, principalmente no Estado de São Paulo, produziram imagens idealizadas e pictóricas no ambiente citadino, nas quais o rural refere-se a um mundo de base agrícola que está distante e desconectado da modernidade citadina. Porém, isto pouco condiz com a realidade de muitas áreas agrícolas, principalmente, porque a identidade desenhada nos traços da figura do 'caipira' tipicamente rústico, que habitaria áreas abandonadas e precárias no aguardo por melhorias proporcionadas pelo desenvolvimento urbano, está cada vez mais sendo transformada pelo tempo em crescentes manifestações de individualismo e secularização (CÂNDIDO, 1964, p. 11). Entretanto, este fenômeno não necessariamente anuncia o fim das famílias rurais e tampouco a completa industrialização da agricultura.

Contudo, deve-se destacar que a denominação de rural, mesmo sendo um tipo social da cultura do campo, refere-se à localização de uma área que vai sofrendo influências e alterações ao longo do contínuo rural-urbano (CÂNDIDO, 1964, p. 27), enquanto a agricultura é uma atividade econômica que pode ser realizada independentemente de sua localização. A agricultura de âmbito familiar e o mundo rural não são sinônimos, porém, frequentemente são vinculados resultando na associação direta entre o espaço rural e sua natureza setorial, e relegando toda a complexidade territorial que anima as atividades agrícolas ou mesmo a vida rural (ABRAMOVAY, 2000). Isto foi consequência do predomínio de estudos rurais brasileiros com foco de análise baseado na 
função econômica da agricultura no interior do capitalismo, tendo como diretrizes o processo de acumulação do capital e a estrutura de classes.

Tradicionalmente a economia caipira apresentava uma certa autonomia e autossuficiência em relação ao mercado capitalista, pois estava concentrada na dinâmica interna de sua própria comunidade pouco adensada e regulada pelo processo de subsistência. Sua estabilização era fortalecida pelo fato de ser "apresentada em função de níveis mínimos, mas organicamente entrosados, de subsistência e vida social, exprimindo um tipo de economia semifechada, equilíbrio obtido por técnica rudimentar" (CÂNDIDO, 1964, p. 203). A expansão da urbanização sobre áreas rurais, potencializada pelo desenvolvimento industrial, foi um dos principais mecanismos para a incorporação de bens de consumo ao mundo rural e, consequente, abertura de seu mercado. Cada vez mais a economia caipira foi incorporada à economia de mercado, trazendo novas conexões com a estrutura urbana (CÂNDIDO, 1964, p. 207), refletindo grandes crises sociais na cultura caipira.

Com efeito, autores marxistas afirmaram que as consequências deste processo levaria o camponês à miséria porque este não conseguiria resistir às pressões da urbanização. Os altos custos das inovações tecnológicas e a racionalidade econômica de mercado não seriam incorporados pela família agrícola, restando ao agricultor o abandono de suas atividades em busca de empregos urbanos para garantir sua subsistência. Outro caminho possível, para a minoria dos camponeses, seria a incorporação completa da lógica de mercado pelo produtor agrícola, transformando-o em um empresário detentor de seus meios de produção (ABRAMOVAY, 2007, p. 46).

Contudo, a reprodução social da unidade agrícola familiar vem persistindo firmemente às transformações causadas pela integração, cada vez mais intensa, à dinâmica capitalista. Isto vem ocorrendo por meio de um processo de adaptação (econômica, moral e, até mesmo, de conservação ambiental) da agricultura familiar à dinâmica de seu ambiente social através do (1) balanceamento entre as necessidades do núcleo familiar e as pressões externas de mercado; (2) o ambiente de base biológica e seus limites naturais; (3) o perfil pluriativo da unidade familiar (SCHNEIDER, 2002).

A resistência do campesinato frente ao capitalismo existe porque o núcleo familiar, com base nas relações de parentesco e herança, é o fator que regula todo o 
processo de tomada de decisão seja em relação à produção, aos investimentos e ao próprio trabalho desempenhado na lavoura. Isto gera um equilíbrio fundamental para a reprodução social da agricultura familiar porque sua dinâmica interna responde não apenas ao mercado, mas também a uma necessidade social que cria no interior de seu organismo mecanismos de sobrevivência. Estes, diferentemente do trabalhador assalariado, caracterizam o produtor familiar como "sujeito criando sua própria existência" (CHAYANOV apud ABRAMOVAY, 2007, p. 69). Por este motivo, o agricultor se vale de uma racionalidade econômica diferenciada e determinada por parâmetros que não são predominantemente econômicos, mas sim baseados em suas relações familiares e humanas, assim confundindo o trabalho com o modo de viver, no qual a produção e o consumo não são apenas medidas da economia de mercado.

Com efeito, a produção familiar, mesmo sendo dinamizada por elementos como trabalho e bens de produção, apresenta fatores de uma racionalidade não capitalista porque o produtor agrícola familiar é ao mesmo tempo o proprietário, o patrão, o empregado e o arrendatário de si mesmo. Como consequência, a sobrevivência social, econômica, cultural e moral está diretamente relacionada ao bem-estar e à continuidade da unidade familiar, de forma completamente díspar a um proprietário capitalista. A agricultura familiar tem como princípio a íntima relação entre trabalho e gestão, em que o agricultor trabalha na lavoura e, concomitantemente, conduz o processo produtivo. $\mathrm{O}$ agricultor familiar tona-se um verdadeiro "ornitorrinco social” (ABRAMOVAY, 2007, p. 69), pois não se enquadra na estrutura de classe social baseada no explorador e no explorado, mesclando assim a imagem do detentor dos meios de produção ao empregado que vende sua força de trabalho.

O ritmo da produção em uma unidade familiar é determinado pela necessidade de sua família de forma completamente avessa ao empresário capitalista, o qual gere negócios tomando decisões de mercado, tendo suas escolhas pautadas em investimentos e podendo inclusive reduzir sua mão-de-obra demitindo funcionários (CHALITA, 2006). Graziano (1997) apresenta alguns parâmetros para diferenciar a agricultura familiar e um empreendimento com natureza capitalista. O autor aponta que mesmo a unidade de produção agrícola que apresente alguns elementos da racionalidade capitalista, como uma organização de divisão do trabalho e a gestão concentrada parcialmente no proprietário 
que emprega o trabalho assalariado, não pode ser equiparada com a dinâmica do empreendimento capitalista, pois a propriedade agrícola patronal tem como essência a racionalização por meio da divisão completa de funções. Para um produtor familiar tornar-se empresário, a rigor, deve ter sua produção determinada pelo mercado e suas taxas de juros e atividades devem ser completamente separadas dos afazeres produtivos, cabendo-lhe exclusivamente a gestão da produção, fazendo com que os meios de produção efetivem-se como capital (GRAZIANO, 1997). Contudo, o produtor agrícola e sua família desempenham um emaranhado de funções que, por vezes, não são incorporadas às pesquisas sobre o campo, como exemplo, a própria gestão da propriedade que se configuraria como trabalho indireto do próprio produtor.

A tenacidade da agricultura familiar deve-se também a intensa relação entre a agricultura e os ritmos naturais de seu ambiente, pois a base biológica do ambiente não é passível da racionalização e controle da mesma forma que na produção industrial. Essa qualidade ambiental da agricultura foi analisada por Antônio Cândido (1964) quando dissertou a respeito de grupos sociais que se estabeleceram nucleados pelo cultivo da terra. No caso da cultura caipira brasileira, o ambiente, abundante em aspectos naturais, representaria uma totalidade que demarca e coincide com os limites das próprias atividades antrópicas. O conjunto de atividades (trabalho agrícola, caça, pesca, coleta) corresponderiam de forma simbiótica ao processo de utilização do próprio meio, onde a roça, a água, os matos e campos definiriam a dinâmica da cultura, "de tal forma que as atividades do grupo e o meio em que elas se inseriam formavam por sua vez uma continuidade geossocial, um interajuste ecológico, onde cultura e natureza apareciam, a bem dizer, como dois pólos de uma só realidade" (CÂNDIDO, 1964, p. 217).

Como consequência, mesmo com os avanços tecnológicos incorporados à produção agrícola, os obstáculos naturais restringem a exploração capitalista dos recursos ambientais, principalmente, em culturas anuais e de base alimentar. Nem mesmo o valortrabalho consegue ser dominado pelo mercado, pois não é possível estabelecer um controle rígido entre tempo de trabalho e tempo de produção porque cada planta ou animal tem seu próprio ritmo natural de desenvolvimento, seu tempo de resiliência e até mesmo sua perecibilidade. Veiga (2004) aponta que a industrialização não dominará o cultivo agrícola à medida que a produção de alimento depende da transformação 
biológica de energia solar, por este motivo, a dependência de ciclos sazonais naturais da biodiversidade não pode ser transformado em uma produção em série industrial. Todavia, os limites naturais não apresentam a única explicação para a resistência de algumas unidades de produção a certos elementos da lógica capitalista, mas sim fornecem argumentos para compreender os limites da produção industrial impostos pela relação entre natureza e produção agrícola.

Outro fator que corroborou para a persistência da unidade familiar na agricultura foi a facilidade de acesso resultante do aumento da eficácia dos meios de transporte, pois trouxe a proximidade entre os comércios agrícolas, assim colocando em concorrência todas as agriculturas do mundo. Como consequência, os preços de gêneros alimentícios equiparam-se internacionalmente e alinham-se aos baixos valores dos países com alta produtividade e produção excedente, independentemente das diferenças e particularidades locais de produtividade. Com a impossibilidade de concorrência, os pequenos produtores abandonam a especialização agroexportadora e dedicam-se às culturas alimentares de baixo custo e renda, constituindo assim, uma categoria que resistiu a imposição da alta tecnificação na lavoura. Com efeito, a agricultura familiar tornou-se a principal responsável pelo abastecimento alimentar, principalmente, das cidades (MAZOYER, 2009, p. 507).

A agricultura familiar também persiste por conta da capacidade de ajustar a sua força de trabalho às pressões de mercado. Na circunstância em que a concorrência na produção exige o aumento de renda da propriedade, os membros da família adequam sua dinâmica de trabalho em busca de atividades não agrícolas, dentro ou fora da propriedade, com o propósito de obter novas fontes de renda. Este ajustamento entre trabalho e consumo garante a sobrevivência da unidade de produção agrícola. Contudo, no mundo rural sempre houve a combinação de atividades não agrícolas ao cultivo pelo fato de não existir, culturalmente, uma clara divisão social do trabalho e do espaço (SCHNEIDER, 2002). Este fenômeno social e econômico é denominado como pluriatividade e consiste em uma das formas de persistência da agricultura familiar frente a crescente integração à dinâmica das cidades. A pluriatividade, enquanto estratégia de organização do trabalho familiar, possibilita enxergar a propriedade agrícola como uma 
unidade de produção e reprodução social e econômica ampliada para além das atividades agrícolas.

Para Schneider (2002), o conceito de pluriatividade difere-se da noção de parttime farming (agricultores em tempo parcial) destacada pelo autor Graziano (1997), pois este se refere ao uso do tempo de trabalho do produtor mesclando atividades agrícolas e não agrícolas, enquanto a pluriatividade seria a combinação de formas de renda que contemplassem atividades agrícolas com atividades não agrícolas. A pluriatividade pode tornar-se uma ferramenta de desenvolvimento rural porque a alternativa de aumento de renda pode auxiliar a permanência dos agricultores no campo (GRAZIANO, 1997).

Contudo, existem alguns fatores que necessitam de ponderação quando se pretende ampliar as funções da agricultura, pois estas inovações precisam seguir princípios que salvaguardem a proteção do ambiente, a produção voltada para a alimentação e o perfil socioeconômico do agricultor que tem sua fonte de renda associada à atividades complementares ao cultivo da terra. Este último item deve ser destacado porque grande parte dos benefícios públicos, como a concessão de crédito agrícola para a agricultura familiar, condiciona o recebimento destes à produção agrícola como fonte de renda majoritária. Porém, o agricultor localizado em espaços periurbanos normalmente tem pelo menos um membro da família que trabalha na cidade e, com a desvalorização da atividade agrícola, a renda advinda do manejo da terra é inferior, assim dificultando o acesso desta unidade familiar ao enquadramento nos programas públicos em geral.

A continuidade da produção agrícola familiar, como foi apresentada acima, resiste à diversos tipos de ameaças, principalmente, provenientes da industrialização da agricultura e da expansão urbana. Contudo, não é possível afirmar categoricamente que haverá a extinção deste grupo social, afinal, como observa Antônio Cândido (1964), estas formas de persistência da agricultura familiar não são uma "substituição mecânica de padrões", mas sim são elementos que reafirmam modos tradicionais através de redefinições, transformações e ajustes de antigos padrões ao contexto social atual (CÂNDIDO, 1964, p. 108). Deve-se destacar que, a singularidade deste processo tem como elemento-chave a noção de 'família' que pode ser compreendida como:

um grupo social que compartilha um mesmo espaço (não necessariamente uma habitação comum) e possui em comum a propriedade de um pedaço de terra para cultivo agrícola. Está ligada por laços de parentesco e consanguinidade (filiação), podendo a ele pertencer, 
eventualmente, outros membros não consanguíneos (adoção). É no âmbito familiar que se discute e se organiza a inserção produtiva, laboral, social e moral de seus integrantes, e é em função desse referencial que se estabelecem as estratégias individuais e coletivas que visam a garantir a reprodução do grupo. Embora seu objetivo seja a reprodução material, cultural e moral do grupo, não há, para tanto, caminho predeterminado ou estratégias definidas (SCHNEIDER, 2002).

O núcleo familiar torna-se o ponto de inflexão na compreensão da dinâmica do manejo agrícola para além de sua função econômica, pois configura uma unidade de análise de caráter social e não apenas produtivo (CAZELLA, 2009, p. 48). Tentar compreender a agricultura familiar somente pelo viés produtivo é abdicar de sua base real, pois a unidade de produção per si representa somente uma parcela da totalidade do fenômeno e resume-se apenas a um conjunto de procedimentos e estratégias inseridos no complexo emaranhado das relações sociais.

Contudo, a agricultura familiar tornou-se um recurso metodológico que transbordou para a esfera de administração pública. No caso brasileiro, a legitimação do Estado em relação à agricultura familiar tem como marco regulatório a criação do Pronaf (Programa Nacional de Fortalecimento da Agricultura Familiar) em 1996, consistindo na abertura de linhas de crédito agrícola e objetivando a tentativa estatal de fomentar o desenvolvimento do capitalismo na produção agrícola de unidade familiar (CHALITA, 2006). Isto aconteceu devido às tentativas do Estado em associar a pressão dos movimentos campesinos ao desenvolvimento do capitalismo, visando atender as demandas por modernização tecnológica da agricultura e tendo na 'agricultura familiar' uma categoria menos estigmatizado do que 'campesinato' (SCHNEIDER, 2002). Surge então o que Schneider (2002) chama de categoria-síntese, ou seja, a a denominação de agricultura familiar abarca não apenas trabalhadores rurais e pequenos produtores, mas também outras categorias sociais como assentados e arrendatários que não se enquadram como produtores patronais.

No ano da criação do Pronaf (1996) houve um levantamento estatístico acerca dos estabelecimentos de agricultura familiar brasileiro que subsidiou em 2006 o primeiro levantamento oficial estatístico brasileiro, realizado pela parceria entre MDA e IBGE. Foi verificado que o valor bruto de produção (VBP) gerado pela agricultura familiar cresceu 
em todas as regiões do país, além de um aumento no número de estabelecimentos de agricultura familiar, mostrando que quando o produtor familiar recebe apoio suficiente, como exemplo, o subsídio de programas públicos como o Pronaf, ocorre a valorização deste tipo de empreendimento.

A comparação estatística entre estabelecimentos de agricultura familiar com estabelecimentos de agricultura não familiar aponta que o VBP da primeira é $89 \%$ superior à segunda, pois a agricultura familiar (AF) consiste em $38 \%$ do valor bruto de produção gerada (VBP), apesar de menor área. Mesmo a AF totalizando $84,4 \%$ da agricultura, ocupa apenas uma área de $24,3 \%$, enquanto a agricultura patronal é apenas $15,6 \%$, porém tem $75,7 \%$ área ocupada. Os estabelecimentos de agricultura familiar ocupam em média 18,37 ha, à medida que os estabelecimentos de agricultura não familiar têm em média 309,18 ha de área ocupada. As vantagens ao fomento da produção familiar geram um grande número de ocupações profissionais que são duas vezes maior que a construção civil, são mais produtivas, asseguram a preservação ambiental, além de ser a principal fornecedora de alimentos básicos mesmo tendo menor área com lavouras (BRASIL, 2006).

Para contemplar a denominação de agricultura familiar, o empreendimento agrícola deve seguir os critérios da Lei Federal ( $\left.n^{0} 11.326 / 2006\right)$ que definem o enquadramento do estabelecimento agrícola como familiar de acordo com (1) área de tamanho igual ou inferior a quatro módulos fiscais ${ }^{4}$ e (2) ter renda, trabalho e gestão provenientes da unidade família como identifica o quadro acima:

\section{LEI FEDERAL $\mathrm{N}^{\mathrm{O}} 11.326$ - 24 de julho de 2006}

\section{Estabelece as diretrizes para a formulação da Política Nacional da Agricultura Familiar e}

Empreendimentos Familiares Rurais.

Art. 1o Esta Lei estabelece os conceitos, princípios e instrumentos destinados à formulação das políticas públicas direcionadas à Agricultura Familiar e Empreendimentos Familiares Rurais.

Art. $2^{\circ}$ A formulação, gestão e execução da Política Nacional da Agricultura Familiar e Empreendimentos Familiares Rurais serão articuladas, em todas as fases de sua formulação e implementação, com a política agrícola, na forma da lei, e com as políticas voltadas para a reforma agrária.

\footnotetext{
${ }^{4}$ Módulo Fiscal é estabelecido por Município de acordo com a Instrução Especial Incra n ${ }^{\circ} 20$ de 1980.
} 
Art. $3^{\circ}$ Para os efeitos desta Lei, considera-se agricultor familiar e empreendedor familiar rural aquele que pratica atividades no meio rural, atendendo, simultaneamente, aos seguintes requisitos:

I - não detenha, a qualquer título, área maior do que 4 (quatro) módulos fiscais;

II - utilize predominantemente mão-de-obra da própria família nas atividades econômicas do seu estabelecimento ou empreendimento;

III - tenha percentual mínimo da renda familiar originada de atividades econômicas do seu estabelecimento ou empreendimento, na forma definida pelo Poder Executivo;

IV - dirija seu estabelecimento ou empreendimento com sua família.

FIGURA 10: Política Nacional de Agricultura Familiar e Empreendimentos Rurais Familiares

FONTE: Lei Federal (n ${ }^{\circ} 11.326$ - 24 de julho de 2006)

Os valores gerados pelo levantamento estatístico da agricultura familiar no Brasil são fundamentais para o questionamento de algumas conclusões errôneas acerca da produtividade agrícola no país. A maior produtividade de alimentos do cultivo agrícola de base familiar, mesmo em menor área, demonstra que o modelo agroindustrial não salvaguarda a segurança alimentar, além dos alto custos e desenvolvimento de tecnologias que exploram e poluem o ambiente natural.

\subsection{A CIDADE É O QUE O CAMPO NÃO É?}

Como descrito acima, a agricultura familiar e seu contexto rural cada vez mais integram-se à dinâmica da urbanização manifestando, ora pela influência da invisível lógica de mercado, assim como pelas novas organizações territoriais de espaços periurbanos que conjugam realidades urbanas e rurais. Este cenário apresenta a necessidade de emergirem novos princípios teóricos e reflexivos acerca da cidade, do campo, do urbano e do rural com o intuito de abarcar sentidos renovados que condizem com as realidades espaciais da cidade.

O 'urbano' e o 'rural' constituem-se como a adjetivação do conjunto de relações socioeconômicas e espaciais emanados da cidade e do campo respectivamente (MONTMÓR, 2004). A 'cidade' e o 'campo' podem ser observados como formas e dinâmicas dos elementos socioespaciais que são diferenciados pela divisão territorial do trabalho. Sérgio Buarque de Hollanda (1995) ao dissertar sobre a formação brasileira aponta que a 
estrutura da sociedade foi estabelecida fora do mundo urbano porque a dinâmica colonial concentrava-se nas propriedades rurais. As cidades eram simples núcleos dependentes do poder consolidado no mundo rural até o período da Abolição (HOLLANDA, 1995, p. 73), de forma completamente contrária a ideia de cidade como centro de poder.

Muitos estudos acadêmicos que examinam a noção de urbano e suas transformações na relação cidade-campo referenciam Henri Lefebvre pelo fato deste trazer em suas obras a hipótese que acontecerá a "urbanização completa da sociedade" (LEFEBVRE, 1999, p. 13). Não cabe ao presente estudo avaliar se a assertiva será concretizada, mas junto a esta argumentação existe um sentido pertinente de urbano, sendo tratado não apenas a partir da identificação material de infraestrutura urbana na paisagem, mas sim como qualidade virtual que irradia em todas as esferas da vida. O que interessa como objeto de análise, aliado ao entendimento da configuração morfológica, é o urbano enquanto manifestação socioespacial que adentra nos aspectos e sentidos imateriais da localidade, penetrando assim nas relações sociais e nas relações de produção da sociedade urbano-industrial. Segundo Lefebvre, o urbano no mundo contemporâneo nasceu da industrialização (LEFEBVRE, 2001, p.14), a qual trouxe a produção e a classe trabalhadora para o centro de poder. Pelo fato da expansão urbana irradiar da cidade na era industrial, esta ganha a função de "não mais apenas controlar e comercializar a produção do campo, mas também transformar e a ela agregar valor em formas e quantidades jamais vistas anteriormente" (MONTE-MOR, 2004).

Portanto, as definições de urbano e cidade apresentam-se distintas porque, mesmo havendo nexos profundos entre ambas, a cidade é a morfologia material do aglomerado urbano que concretiza as condições de trabalho, produção e mercado. O urbano, por sua vez, pode ser traduzido numa espécie de morfologia social que carrega consigo a práxis urbana (MONT-MÓR, 2004) e prolonga a lógica urbano-industrial para além do aglomerado da cidade, espraiando-se pelas áreas periféricas da cidade. Este fenômeno resulta de incentivos públicos para ampliação do perímetro urbano e da ação do mercado imobiliário que transformam terras rurais em loteamentos urbanos. Isto concretiza-se na dinâmica desigual de produção do espaço "de modo a viabilizar o processo de reprodução do capital" (SCHNEIDER, 2002). 
A concentração demográfica e sua dinâmica populacional são critérios constantemente utilizados para definir teoricamente a cidade, inclusive porque a aglomeração normalmente sedia a infraestrutura urbana, equipamentos públicos, e um modus operandi urbano. Outras características também podem ser pautadas para delimitar cidades como a extensão territorial, a concentração espacial, a economia urbana ligadas aos setores secundários e terciários, a integração com telecomunicação e transporte, a divisão e a especialização do trabalho.

Entretanto, na esfera da administração pública brasileira os termos 'urbano' e 'cidade' são tratados como sinônimos, pois a cidade é estabelecida onde existe urbanização. Com efeito, o critério de ordenamento do uso e ocupação da terra é definido pelo poder municipal que, através da Lei do Perímetro Urbano contida no Plano Diretor Estratégico, estabelece as porções territoriais que serão regulamentadas como áreas urbanas. Porém, o estabelecimento de áreas urbanas obedece a um critério estritamente legal, em que o urbano é a área delimitada pelo perímetro urbano. Como consequência, áreas com paisagens predominantemente rurais, por vezes, são estabelecidas como urbanas porque esta prática valoriza o preço da terra e a sede municipal tem autonomia para estabelecer como urbana qualquer área de pequena concentração demográfica atendida por um mínimo de serviços públicos e infraestrutura urbana; independentemente de seus aspectos geográficos, econômicos ou culturais (ABRAMOVAY, 2000). O espaço restante, com pouco desenvolvimento urbano e carente de infraestrutura e serviços, é denominado como área rural. Esta lógica rebate nas taxas de urbanização brasileira que têm crescimento exponencial, causando uma série de impactos ambientais e sociais na sociedade, principalmente, por conta da falta de rigor e planejamento no estabelecimento dos perímetros urbanos.

Este movimento de propagação do urbano cria espaços peculiares que são zonas de transição entre a cidade e o campo nos arrabaldes do aglomerado urbano, alterando as morfologias urbanas a ponto de não ser possível delimitar com precisão áreas urbanas e rurais. A dualidade campo-cidade, nestes espaços, não está separada de forma dicotômica, mas sim combinada em atividades urbanas e agrícolas que, através da disputa pelo o uso e a ocupação da terra, dinamizam os espaços periurbanos. Este termo 'periurbano' apresenta uma polissemia de conceitos pelo fato de referir-se a um espaço 
periférico à cidade que, dependendo do contexto local, sofre influência direta de realidades urbanas ou rurais. O espaço periurbano configura-se como uma zona de contato entre diferentes conjunturas emaranhadas de complexidade, ampliando de forma reflexiva o debate acerca da diferenciação entre núcleos urbanos e povoados rurais.

Contudo, é possível ponderar características comuns às diferentes realidades periurbanas cujos territórios preservam características rurais como baixa densidade demográfica, paisagens naturais e propriedades agrícolas. Estas, ao mesmo tempo que estão à margem também integram-se à dinâmica urbana seja pelo sistema viário, pela dependência dos recursos, pelas fontes de emprego e renda (VALLETE, 2004), pela administração pública e, sobretudo, pelo seu potencial ambiental. A constituição destas zonas de transição não necessariamente anunciam a 'desruralização' ou mesmo a superação da distinção entre cidade e campo como unidades espaciais, mas sim compartilham formas de uso da terra, de relações sociais, de interesses econômicos e políticos na cadência do conflito entre a pressão urbano-industrial e a proteção de práticas que valorizam o cuidado com a terra e seus recursos naturais.

Neste sentido, destaca-se a justaposição de três tipos de espaços importantes para a compreensão analítica de áreas periurbanas (CORELLANO ${ }^{5}$ apud VALE, 2005): (1) os espaços naturais que podem ser compreendidos como: áreas de importância ecológica com pouca interferência antrópica cujos usos e funções, trazem em si, a potencialidade de equalizar de forma concreta a proteção da qualidade ambiental às atividades socioeconômica de ecoturismo, educação ambiental e valorização da realidade local pelo privilégio do contato direto com a natureza; (2) espaços rurais de uso agropecuário e florestal que, por meio do manejo de tecnologias de baixo impacto ambiental, podem formar uma área intermediária entre o uso antrópico e a preservação ambiental constituindo uma rica fonte de alimentos saudáveis e valorização de traços culturais rurais, além de ser uma importante barreira para contenção de loteamentos urbanos; (3) o espaço urbano que, não menos importante, deve ser planejado de forma estratégica

\footnotetext{
${ }^{5}$ CORELLANO, F. P.El ciclo del agua y la reconversión del paisaje periurbano en las ciudad de la red C-6. In: MONCLÚS, F. J. La ciudad dispersa - Suburbanización y nuevas periferias. Barcelona: Centre de Cultura Contemporània de Barcelona, 1998, p.111-142 (Urbanismo, ciudad, historia I).
} 
integrando melhorias em relação à infraestrutura e à comunicação à valorização e fortalecimento dos espaços naturais e rurais.

As delimitações dos espaços periurbanos passam por uma série de variantes operacionais que encontram-se em constantes transformações físicas, econômicas e sociais. Entretanto, novos trabalhos acadêmicos buscam a conceituação de periurbano, mas pouco convergem sobre o tema. Alguns autores consideram periurbanas as áreas urbanizadas da zona rural, sendo até mesmo cunhado por Vallete (2004) o termo territórios rurais periurbanos.

Contudo, a realidade brasileira possui a tendência de estabelecer perímetros urbanos em áreas potencialmente rurais, tornando difícil associar exclusivamente o espaço periurbano às áreas rurais. Isto ocorre especialmente porque as áreas denominadas como 'urbanas' na atualidade brasileira, muitas vezes, constituem mosaicos de espaços denominados:

espaços urbanos, suburbanos, rurais agrícolas e rurais não agrícolas, articulados sistemicamente entre si, às vezes de forma conflituosa (suburbanização degenerada por usos do solo e patrimônio não urbanos, por exemplo) e às vezes de forma simbiótica (corredores verdes, regeneração urbanística e socioeconômica de espaços construídos tradicionais, etc.), recuperando-se, nestes últimos, algumas componentes da complementaridade que caracterizou a relação tradicional urbano-rural (FERRÃO, 2000).

A grande potência reside na simbiose existente entre a cidade, o espaço periurbano e o campo. A análise destes espaços, que são cunhados por diversas nomenclaturas como rururbano, novo rural ou mesmo periurbanos faz emergir novas formas de planejar morfologias urbanas e rurais, as quais sofrem separações arbitrárias contidas em estudos técnicos que enquadram realidades de forma cindida. Isto resulta na deficiência de entendimento “dos processos de mutação social e espacial de regiões urbanas" (ESPAÑA ${ }^{6}$ apud VALE, 2005), ou seja, no próprio entendimento da realidade local.

\footnotetext{
${ }^{6}$ ESPAÑA, E. D. La agricultura en espacios periurbanos en el municipio de Alboraya. Valencia: Universidad de Valencia, 1991.
} 
Com efeito, cabe à presente pesquisa compreender o periurbano como um espaço com predominância de área naturais, agrícolas e de pequenos aglomerados urbanos que, situado ao redor da mancha urbana consolidada, independente de sua localização (urbana ou rural), sofre forte pressão do constante processo de urbanização irradiado da cidade. A valorização destes espaços periurbanos deve ser advinda da sua importância enquanto barreira para atenuar a expansão urbana e, concomitantemente, proteger as áreas preservadas mais distantes. Para este efeito, é necessário existir instrumentos legislativos e fiscalizatórios objetivando o congelamento do crescimento urbano sobre estas áreas de importância ambiental, além de políticas públicas para estimular outros tipos de ocupação que valorizem a permeabilidade da terra.

A área de estudo APA Bororé-Colônia apresenta um grande potencial periurbano, pois seu perímetro está localizado no gradiente de urbanização entre a mancha urbana consolidada e as áreas preservadas da APA Capivari-Monos. É possível verificar que algumas áreas urbanizadas da periferia (ou suburbanas) extrapolam o limite norte da APA Bororé-Colônia, porém a urbanização de seu território é predominantemente difusa, assim formando pequenos núcleos de ocupação e baixa densidade demográfica próximos às vias principais e descontínuos à mancha urbana. Estes núcleos recortam a predominante paisagem natural e justapõem-se à propriedades agrícolas, as quais tornamse mais proeminentes ao sul do território e estão adjacente aos limites da potencial zona rural no território da APA Capivari-Monos. Por esta série de motivos, a APA BororéColônia justifica-se como um espaço periurbano porque, por um lado, está completamente integrada à dinâmica urbana para ser estabelecida como área rural e, por outro, seus núcleos urbanos não são contíguos à mancha urbana consolidada, além da predominância de paisagens naturais e propriedades agrícolas que descaracterizam assim a denominação de áreas exclusivamente urbanas, suburbanas ou da periferia urbana. Entretanto, mesmo que seus limites estejam compreendidos no perímetro urbano paulistano, a área é protegida por legislações ambientais nos níveis federal, estadual e municipal, visto que constitui importantes bacias hidrográficas fundamentais para o abastecimento hídrico do município. 
Isto caracteriza outra especificidade de territórios periurbanos: a grande sobreposição de perímetros e competências institucionais ${ }^{7}$, complexificando ainda mais o entendimento da área (VALlETE, 2004). Por este motivo, é necessário entender o arranjo territorial local das cidades e seu entorno para o estabelecimento das zonas de expansão urbana, pois no contexto da presente pesquisa o periurbano não deve ser compreendido como zona de expansão urbana, mas sim como uma zona mista de desenvolvimento sustentável com mecanismos de proteção ambiental e contensão da expansão urbana, afinal, como o Prof. Dr. Nabil Bonduki aponta: “em São Paulo não existe mais a possibilidade de ter expansão urbana" (trecho entrevista Nabil Bonduki, agosto de 2012).

No contexto europeu, o espaço periurbano entrou em pauta no campo acadêmico e até mesmo em propostas de zoneamento das cidades (ABRAMOVAY, 2000). É possível observar nas cidades europeias uma espécie de coroa periurbana, distanciada do centro, que mescla atividades rurais e urbanas. Segundo Trigal (2003) o perfil dos habitantes de bairros periféricos espanhóis são de migrantes do meio rural, enquanto nos espaços periurbanos encontram-se moradores de origem urbana e alguns poucos proprietários rurais que resistiram ao processo de expansão urbana. Vallete (2004) ao analisar o espaço periurbano na província de Montpellier na França, aponta que para os moradores periurbanos a identidade com este espaço é ambivalente, pois a cidade é a referencia do local de trabalho e consumo, enquanto que a paisagem rural e natural também influencia o imaginário coletivo formando uma identidade que mescla o urbano e o rural. Na realidade local da APA Bororé-Colônia a dificuldade de monitoramento da ocupação antrópica torna extremamente complexo a delimitação de perfis dos moradores locais, inclusive porque são migrantes de diversos contextos. Em certas porções do território é possível encontrar populações de baixa renda em uma dinâmica de violência e

$7 \quad$ No caso da APA Bororé-Colônia, o emaranhado de limites administrativos do território consiste em: porção da Subprefeitura de Capela do Socorro, porção da Subprefeitura de Parelheiros, parte da bacia hidrográfica da represa Billings e sua APRM-B, parte da bacia hidrográfica da represa Guarapiranga e sua APRM-G, três Parques Naturais Municipais (Itaim, Varginha e Bororé). Cabe destacar, que esta confluência de perímetros, sua geomorfologia e a dinâmica social ampliam as ações para além dos limites da APA Bororé-Colônia, especialmente no sentido sul da APA Capivari-Monos. 
vulnerabilidade social superpostas à paisagem natural, propriedades agrícolas e chácaras de lazer.

Isto posto, uma conclusão possível é que estes territórios devem ser valorizados por sua especificidade de não ser nem cidade e nem campo (VALLETE, 2004), e potencializadas pela compreensão de sua realidade. Práticas inovadoras surgem na busca pelas formas simbióticas rural-urbano, abrindo caminhos para ações e projetos de desenvolvimento local, assim constituindo novas formas de integrar espaços ambientalmente preservados à dinâmica urbana. Como exemplo, a agricultura, especialmente agroecológica, é cada vez mais percebida como um dos agentes que conectam os seres humanos à natureza, sendo assim uma dimensão estratégica de fortalecimento das relações entre a sociedade e o espaço (SCHNEIDER, 2002). Os espaços periurbanos reservam valores que cada vez mais fazem parte dos anseios da população das cidades, ou seja, a busca urbana pela imagem da qualidade de vida em meio à natureza (VALLETE, 2004), assim equalizando a necessidade por espaços naturais ao dinamismo do modus operandi urbano.

\subsection{ATIVIDADES OU LOCALIZAÇÕES?}

No caso do Município de São Paulo, a grande confusão entre localização e atividade trouxe a superação ${ }^{8}$ do território rural em seu Plano Diretor Estratégico Municipal e a adjetivação 'urbana' e 'periurbana' à agricultura. Como consequência, a atividade agrícola, que sempre foi normatizada em áreas rurais, adentra na agenda de políticas públicas municipais, especialmente, por sua relevância no que tange a conservação ambiental. Inicialmente, é necessário compreender as dimensões e temas que orbitam a complexa conceituação da agricultura urbana e periurbana, principalmente, porque configura-se como um fenômeno que vem sendo valorizado em um período relativamente recente.

O autor Mongeot (2010) é bastante referenciado nos textos acerca deste tema porque associa o conceito de agricultura urbana e periurbana à uma matriz multifuncional

\footnotetext{
${ }^{8}$ A superação do território rural no Plano Diretor Estratégico Municipal será aprofundada no próximo capítulo.
} 
que está diretamente associado ao ecossistema (econômico e ecológico) urbano. Para este autor, o cultivo da terra é similar em qualquer localização, pois suas características enquanto processo de atividades econômicas (produção, processamento e comercialização), tipificação de escala e de áreas de cultivo, assistência técnica, necessidade de insumos, entre outros; podem ser empregados igualmente à agricultura rural, sendo que a diferença está na indicação da localização (urbana ou periurbana). Com efeito, os elementos que distinguem a agricultura urbana e periurbana da agricultura rural são as consequências geradas pela proximidade e integração direta com o ecossistema urbano, como exemplo, a maior proximidade com o mercado consumidor e as resultantes diretas causadas pela influência da cidade.

Contudo, mesmo partindo do princípio que agricultura é uma atividade que independe da localização, há uma grande distinção entre a agricultura praticada no espaço intraurbano e periurbano. A agricultura é denominada como 'urbana' à medida que o cultivo está localizado entremeado à infraestrutura urbana, tendo como fator limitante a pouca disponibilidade de superfície agricultável ou mesmo completa ausência, utilizando vasos ou estruturas similares para a atividade agrícola. Sua função, por vezes, cumpre a finalidade de autoconsumo, fins educativos ou até mesmo o propósito de ocupação do espaço público urbano. Evidentemente é possível haver terrenos com produção para comercialização em menor escala ou até mesmo produções agrícolas em áreas urbanas ociosas, como exemplo, a faixa de servidão localizada embaixo do conjunto de torres de linha de transmissão. A zona leste do município de São Paulo apresenta cerca de setenta unidades de produção agrícola localizadas em áreas dentro da infraestrutura urbana e, em parte, situadas embaixo de linhões de transmissão elétrica.

Entretanto, a agricultura em espaços periurbanos é realizada em áreas que reservam terrenos permeáveis e naturais para um manejo agrícola com características rurais e com maior potencialidade para a produção de escala comercial. Usualmente, o perfil dos agricultores residentes no espaço periurbano é de produtores remanescentes do período em que àquele espaço configurava-se como rural ou mesmo de citadinos que procuram um contato maior com a natureza, à exemplo, dos chamados neo-rurais. Mesmo com esta grande distinção, poucos autores fazem a separação clara entre as 
definições de agricultura praticada no espaço intraurbano e a agricultura realizada em espaços periurbanos, causando demasiadas confusões entre os termos.

A delimitação da agricultura urbana pode seguir os critérios que caracterizam sua localização como número de habitantes, densidade mínima, perímetro urbano ou até mesmo o zoneamento das cidades (MONGEOT, 2010). Porém, o estabelecimento da agricultura periurbana é mais problemático, visto que não há uma noção clara a respeito dos critérios que definem o espaço periurbano por conta da proximidade tanto de áreas urbanas, como de áreas rurais. Mesmo indicando a diferença entre agricultura urbana e periurbana, a definição proposta pelo autor conjuga as duas realidades:

A agricultura urbana é praticada dentro (intraurbana) ou na periferia (periurbana) dos centros urbanos (sejam eles pequenas localidades, cidades ou até megalópoles), onde cultiva, produz, cria, processa e distribui uma variedade de produtos alimentícios e não alimentícios, (re)utiliza largamente os recursos humanos e materiais e os produtos e serviços encontrados dentro e em torno da área urbana, e, por sua vez, oferece recursos humanos e materiais, produtos e serviços para essa mesma área urbana (MONGEOT, 2010).

Contudo, cada vez mais as definições alinham-se com a configuração encontrada na realidade, como exemplo, os parâmetros da FAO que definem agricultura periurbana como "unidades agrícolas situadas perto da área urbana que exploram intensivamente granjas comerciais ou semicomerciais, cultivando hortaliças e outros produtos hortícolas, criando frangos e outros animais, além de produzir leite e ovos" (BRASIL, 2006). Na América do Sul e Central existem diversos exemplos de agricultura urbana e periurbana compondo políticas públicas municipais como a Declaração de Quito no Equador lançada em 2000. O Ministério da Agricultura (MAPA), no Brasil, amplia a definição de agricultura urbana da seguinte forma: "não se resume apenas ao plantio de espécies destinadas à alimentação, mas a todos os aspectos ligados ao manejo da biodiversidade e ao meio ambiente" (BRASIL, 2006).

Diversos conceitos emergem deste tema que é tão recente no mundo acadêmico e nas definições de políticas públicas. Entretanto, na realidade brasileira o Ministério do Desenvolvimento Social e Combate à Fome (MDS) vem lançando editais para a promoção da agricultura urbana e periurbana, especialmente, para financiar inciativas 
ligadas à Segurança Alimentar e Nutricional (SAN) a fim de garantir o direito à alimentação de qualidade baseado na Lei Federal ( $\left.n^{0} 11.346 / 2006\right)$, a qual criou o Sistema Nacional de Segurança Alimentar e Nutricional.

Muitos questionamentos surgem ao relacionar a agricultura com o espaço urbano ou periurbano, pois não existem respostas concretas acerca de: como normatizar a agricultura no perímetro urbano? Qual seria o perfil do agricultor urbano e periurbano, visto que a facilidade de acesso à cidade faz com que pelo menos algum membro da família exerça atividade urbana, a qual normalmente tem maior valor na renda do que a atividade agrícola? Onde buscar apoio técnico e financeiro, afinal grande parte dos benefícios agrícolas no âmbito familiar estão atrelados à localização rural? Contudo, os espaços periurbanos podem vir a orientar processos de busca por uma adequação às novas realidades, as quais estão para além do debate acerca da diferenciação entre urbano e rural.

\subsection{AGROECOLOGIA E MULTIFUNCIONALIDADE}

Uma das grandes inovações da agricultura em espaços periurbanos são as práticas de manejo agroecológico, as quais vem sendo fortalecidas pelo poder público no Município de São Paulo objetivando estratégias de conservação ambiental para recuperação e proteção das áreas de mananciais, além de funcionar como barreira de contenção do espraiamento da mancha urbana consolidada. Esta associação da atividade agrícola, com funções para além do abastecimento alimentar, pode ser chamada de multifuncionalidade da agricultura. Neste sentido, o cultivo da terra pode ser reconhecido pelas múltiplas funções que exerce, pois é uma atividade que tem características inerentes à proteção da natureza como: baixa densidade populacional, proteção e manutenção da permeabilidade da terra e dos recursos hídricos, assim configurando uma das melhores formas econômicas e ambientais do uso da terra em áreas de mananciais (CARVALHO, 2005).

A integração das funções da agricultura também representa a otimização e a racionalidade do processo, pois uma unidade de produção agrícola familiar baseada em práticas agroecológicas, ao mesmo tempo, preserva o tecido em que se apoia a lavoura, 
fornece uma base alimentar de qualidade, protege a paisagem natural e rural, além de gerar emprego e renda pela venda de produtos e prestação de serviços de turismo e lazer. Como consequência, a atividade agrícola, além da produção privada que sustenta a família, transborda para a esfera pública através da produção de bens públicos e serviços tangenciados pela segurança alimentar, preservação ambiental e manutenção das dinâmicas sociais e culturais, assim desmembrando a agricultura em produtos e serviço (CAZELLA, 2009, p. 297).

Este potencial ambiental reacendeu os estudos acadêmicos brasileiros rurais e agrícolas a partir da década de 1990, sobretudo pela integração entre agricultura familiar e a temática ambiental (SCHNEIDER, 2002), visto que o manejo em menor escala permite uma integração maior com o ambiente natural e pode se tornar uma importante ferramenta de conservação ambiental. Com efeito, além da função ambiental, a multifuncionalidade da agricultura pode ser traduzida como um novo olhar a respeito das dinâmicas de reprodução social das famílias que vivem da terra, pois a agricultura familiar representa uma categoria que contém per si todas as potencialidades para exercer múltiplas funções relacionadas entre si. Por este motivo, os(as) agricultores(as) podem ser valorizados como guardiões de bens públicos naturais e culturais que são compartilhados por todos habitantes do planeta. A multifuncionalidade da agricultura precisa ser incorporada às dinâmicas sociais para garantir o desenvolvimento de ações e estratégias do poder público, das redes de ONGs e de iniciativas privadas.

Contudo, a construção de políticas públicas deve traduzir visões de mundo que promovam a permanência das práticas agrícolas por meio das necessidades reais das famílias agrícolas expressas em seus territórios e em suas dinâmicas, as quais podem ser compreendidas como a "tradução no espaço e no tempo das repercussões econômica, social, política e ambiental das ações de atores e das relações (alianças e conflitos) entre eles" (CAZELLA, 2009, p. 60). Contudo, é necessário ponderar os conflitos entre a legislação ambiental e as práticas agrícolas familiares na realidade brasileira visto que os(as) agricultores(as) correm sérios riscos com a grande burocratização e custos para adequação ambiental. As sanções ambientais e falta de estratégias que fomentem incentivos do poder público, para fortalecimento da agricultura enquanto estratégia de conservação ambiental, podem ser responsáveis pelo enfraquecimento da própria 
agricultura. Outro risco é o crescente deslocamento da função agrícola fundamental, que é a segurança alimentar, para a exclusiva função de conservação ambiental que pode reduzir a agricultura apenas à sua função paisagista (CAZELLA, 2009, p. 15).

As políticas públicas específicas de caráter ambiental devem partir de uma agenda positiva, a fim de subsidiar as bases socioeconômicas da agricultura familiar e de promover a segurança alimentar, social e econômica das próprias famílias produtoras de alimento, além da remuneração de suas funções ambientais. As cidades têm um importante papel neste processo, pois a valorização da multifuncionalidade da agricultura surge, em grande parte, das necessidades advindas dos extensos aglomerados urbanos por qualidade ambiental e preservação dos recursos naturais vitais. Com efeito, pode-se afirmar que na procura urbana, pela valorização do equilíbrio ambiental e pelas atividades de turismo e lazer ecológicos, reside a viabilidade de transformar o mundo rural e agrícola em espaços multifuncionais (FERRÃO, 2000).

Contudo, a proteção da biodiversidade depende de um manejo agrícola, isento de venenos e adubos sintéticos, que seja equilibrado com as dinâmicas ecológicas. Por este motivo, os princípios e práticas agroecológicas tornam-se centrais para repensar o modelo agrícola brasileiro e entram na agenda das políticas públicas como a Lei Federal $\left(\mathrm{n}^{\mathrm{0}}\right.$ 10.831/2003) que regulamenta a agricultura orgânica e o Decreto $\left(n^{0} 7.794 / 2012\right)$ que normatiza a Política Nacional de Agroecologia e Produção Orgânica (PNAPO). Isto mostra um avanço no fortalecimento da agricultura em bases agroecológicas, pois o Brasil apresenta um histórico de subsídios à atividade agrícola patronal e convencional que, mesmo com menor produtividade comprovada, ganha destaque no modelo agrícola brasileiro baseado no 'pacote tecnológico' proveniente do grande movimento de extensão rural cunhado como Revolução Verde.

\subsection{OS MANEJOS DA TERRA}

Os modelos agrícolas desenvolvidos na história da agricultura mundial conjugam a noção de natureza à uma grande diversidade de manejos antrópico que variam de acordo com o momento histórico, a região, o tipo de solo e as técnicas empregadas. 
Abaixo segue uma síntese de alguns marcos do detalhado percurso histórico que o autor Mazoyer (1997) apresenta:

\begin{tabular}{|c|c|}
\hline PERÍODO & TIPO DE MANEJO AGRÍCOLA \\
\hline \multirow[b]{2}{*}{$\begin{array}{l}\text { NEOLÍTICO } \\
(10 \text { mil a.C. }-3 \text { mil a.C. })\end{array}$} & $\begin{array}{l}\text { Sociedades agrárias neolíticas } \\
\text { cultivadores de derrubada-queimada dos meios arbóreos }\end{array}$ \\
\hline & $\begin{array}{l}\text { Fim do Neolítico } \\
\text { utilização de ferramentas como machado e fogo possibilitou o } \\
\text { desmatamento resultando na variação de manejo agrícola }\end{array}$ \\
\hline $\begin{array}{l}\text { IDADE DOS METAIS } \\
(3 \text { mil a.C. })\end{array}$ & $\begin{array}{l}\text { Sistemas agrários pós-florestais diferenciados } \\
\text { possibilidades pelo progresso do desmatamento }\end{array}$ \\
\hline \multirow[b]{2}{*}{ ANTIGUIDADE } & $\begin{array}{l}\text { Idade de ferro } \\
\text { utilização de instrumentos como machados e enxadas }\end{array}$ \\
\hline & $\begin{array}{l}\text { Fim da Antiguidade } \\
\text { cultivo com tração animal leve nos sistemas hidroagrícolas e nos } \\
\text { sistemas de alqueive (cultivo + pastagem) } \\
\text { nas regiões do Oriente Médio, África e Ásia }\end{array}$ \\
\hline IDADE MÉDIA & $\begin{array}{l}\text { Cultivo de tração pesada com arado, grade e carreta } \\
\text { utilização de energia hidráulica e eólica com moinhos } \\
\text { noroeste da Europa e regiões da Ásia }\end{array}$ \\
\hline $\begin{array}{l}\text { PERÍODO DA } \\
\text { COLONIZAÇÃO }\end{array}$ & $\begin{array}{l}\text { Grande intercâmbio de produtos agrícolas e animais domésticos } \\
\text { entre a América e a Europa. }\end{array}$ \\
\hline
\end{tabular}

FIGURA 11: Histórico da agricultura

FONTE: (MAZOYER, 1997)

É possível identificar que o desenvolvimento do ferramental e técnicas agrícolas, seguido da incorporação da tração animal ao cultivo, uso de energia proveniente dos recursos naturais e o grande intercâmbio entre as diversas regiões produtoras do mundo caracterizam elementos transformadores do manejo da terra. Contudo, esta simbiose entre o manejo agrícola e o ambiente natural sofreu uma grande transformação a partir das 
chamadas Revoluções Agrícolas. A primeira ocorreu no século XIX, período em que o desenvolvimento industrial fomentou uma das maiores inovações para o cultivo por meio da mecanização conjugada ao uso de tração animal. O próximo século foi marcado pela adequação de um pacote tecnológico à agricultura, o qual disseminou a segunda Revolução Agrícola em escala mundial.

\subsection{A REVOLUÇÃO VERDE}

O século XX, sobretudo após a Segunda Guerra Mundial, apresentou a grande transformação da produção agrícola mundial, pois a incorporação de avanços tecnológicos à lavoura resultou em um extraordinário aumento da produção por meio da chamada Segunda Revolução Agrícola. Este advento foi acompanhado pela chamada 'Revolução Verde', a qual consiste em um grande movimento de extensão rural que pretendia aumentar a capacidade da produção agrícola mundial por meio da disseminação de um padrão tecnológico desenvolvido pelos EUA e pela Europa. A grande promessa da da Revolução Verde era erradicar a fome por meio da substituição dos saberes locais ou tradicionais pelo manejo científico-tecnológico, assim permitindo um maior controle das intempéries naturais, diminuição do trabalho humano na lavoura e uma maior produtividade a partir de um moderno 'pacote tecnológico' (EHLERS, 1999, p. 32).

Os agricultores que aderiam a este modelo de produção compravam insumos agrícolas resistentes às condições biológicas do ambiente reunindo: sementes geneticamente selecionadas, ou até modificadas como o caso dos transgênicos, extremamente produtivas e compatíveis com os fertilizantes minerais industriais; em conjunto com agrotóxicos de grande capacidade herbicida e equipamentos motomecanizados. O 'pacote tecnológico' ofereceu um conjunto homogêneo de técnicas para serem aplicadas preferencialmente em sistemas de monocultura, altamente controlados, que viabilizavam, por sua vez, a adoção em larga escala. Este movimento foi fortalecido por vários órgãos governamentais, à exemplo da FAO, sendo um dos motivos da grande adesão (EHLERS, 1999, p. 33).

Entretanto, as consequências ambientais resultantes da Revolução Verde são inúmeras, pois a falta de interação com os sistemas biológicos causou esgotamento da 
fertilidade do solo, contaminação de lençóis freáticos e corpos d'água, erosão, salinização, perda da biodiversidade, aumento de pragas e doenças, contaminação de recursos naturais, dos alimentos e dos próprios trabalhadores envolvidos nas atividades. Isto ocorreu porque o desenvolvimento de estudos e da contínua aplicação de componentes químicos para aumento da base de nutrientes do solo, visando o aumento da produção e relegando a fertilidade da matéria orgânica, gerou um grande empobrecimento da terra. Contudo, o crescente esgotamento do solo ocasionou a necessidade de aumento esporádico da dosagem de adubos minerais, e a incidência de pragas e doenças por conta do desequilíbrio ecológico fez crescer a aplicação de venenos agrotóxicos. Isto resultou uma série de impactos ambientais, sociais e financeiros, aumentando o custo da produção e da proporção de insumos minerais, além da contaminação dos próprios agricultores, da terra, das águas e dos animais. A modernização da agricultura também provocou a diminuição de técnicas tradicionais que fortalecem as qualidades ambientais da lavoura como a policultura, a rotação de culturas e a adubação orgânica (ALMEIDA, 2009, p. 58). O manejo animal também sofreu consequências com as constantes modificações genéticas para aumento da produção de leite e carne, além de confinamentos, alimentação modificada, ingestão de antibióticos e hormônios, e contaminação por efluentes advindos do próprio confinamento.

Os impactos da Revolução Verde sobre os agricultores, especialmente os pequenos produtores, são imensuráveis, pois os melhoramentos químicos e tecnológicos beneficiaram os grandes produtores patronais que tinham condições financeiras e espaciais para arcar com o 'pacote tecnológico'. Isto multiplicou dezenas de vezes a produtividade entre o manejo agrícola manual e o motomecanizado, deixando muitos produtores familiares miseráveis por não possuírem condições para a competividade de mercado. Além disso, os insumos industriais beneficiaram agricultores de países desenvolvidos e a motomecanização atingiu apenas a agricultura patronal, sendo que até hoje é possível encontrar países da África, da Ásia e da América Latina que ainda manejam suas lavouras com equipamentos exclusivamente manuais (MAZOYER, 2009, p. 29). Uma grande parte dos pequenos produtores venderam suas propriedades aos produtores patronais, concentrando ainda mais a terra em pequenos grupos e aumentando o êxodo rural. A alta mecanização também gerou a diminuição do emprego de mão-de- 
obra, surgindo lavradores sazonais como o caso brasileiro do "boia-fria" no corte de cana e na colheita do café (EHLERS, 1999, p. 40)

O Brasil prontamente adotou este 'pacote tecnológico' da Revolução Verde, especialmente, nos grandes sistemas monoculturais predominantes na produção agrícola como a cultura de cana-de-açúcar e a produção de soja. Atualmente o consumo brasileiro de agrotóxicos é o maior do planeta, marca atingida por meio de incentivos públicos como o PNDA (Plano Nacional de Defensivos Agrícolas) e a linha de crédito concedida nos anos 1980 aumentando a dependência do produtor e, como consequência, criando um grande mercado consumidor de insumos agrícolas industriais no país.

\subsection{A REVOLUÇÃO SILENCIOSA}

$\mathrm{Na}$ contrapartida deste grande avanço tecnológico agrícola, existe uma série de movimentos que reúnem princípios e tecnologias próprias com o propósito de criar ambientes que harmonizem o ritmo natural com as necessidades e o bem-estar humano, em diversos níveis. Estes movimentos ganham diversas alcunhas como a agroecologia, os populares orgânicos, os sistemas agroflorestais, a agricultura biodinâmica, a permacultura, a agricultura natural entre outros. As diferenciações existem porque cada um tem sua particularidade, entretanto, o equilíbrio com o ambiente natural e a superação do uso de insumos sintéticos exógenos são pontos em comum de todas as vertentes. Como aponta Almeida (2009, p. 61), a característica multifacetada destes movimentos abre espaço para diferentes tipos de interpretação porque, por um lado, é possível definir como formas naturais de produção que protegem o meio ambiente, e por outro, como uma rede de cooperação que valoriza os agricultores e suas práticas tradicionais. Contudo, estas ideias têm em comum um novo tipo de pensamento que integra a atividade agrícola ao seu espaço, assim fortalecendo os atores que trabalham neste e a proteção dos recursos naturais.

Inicialmente, a agroecologia diferencia-se das demais porque não constitui uma forma de manejo agrícola, mas sim uma ciência que estuda a dinâmica dos agro-ecosistemas. Em outras palavras, a agroecologia pode ser conceituada como uma disciplina científica que estuda os sistemas agrícolas na perspectiva ecológica, de modo a orientar o 
manejo e o desenho do agrossistema de forma integral, assim considerando seus aspectos ambientais, sociais, culturais, políticos, éticos entre outros (CAPORAL, 2006, p. 02). Como exemplo, um sistema agrícola degradado e poluído pode ser estudado pela agroecologia, porém sua recuperação será fundamentada no fortalecimento do equilíbrio ambiental, o qual será enriquecido pelos preceitos da ecologia como a sucessão vegetal, a interdependência das formas de vida, a biodiversidade entre outros (CAPORAL, 2006, p. 12).

A ciência agroecológica foi fortalecida academicamente por autores como Miguel Altieri, o qual trouxe a integração das esferas ambiental, social, econômica à agricultura por meio de estudos acerca de sistemas agrícolas tradicionais indígenas (EHLERS, 1999, p.73). Para Altieri, a agroecologia é uma ciência que valoriza a complexidade dos agroecossitemas, trazendo para o manejo agrícola o enfoque ambiental e uma maior sensibilidade aos aspectos sociais. Deve-se destacar, que um sistema agrícola não é um sistema ecológico natural, porém um agroecossitema deve constituir um ecossistema semi-domesticado que precisa sofrer o menor impacto antrópico possível (ALTIERI, 1999, p. 19).

O manejo no sentido agroecológico é fundamentado no potencial endógeno do agroecossistema, por isso alguns princípios podem orientar o desenho de agroecossitemas ambientalmente equilibrados como: o fortalecimento do solo por meio de matéria orgânica da própria propriedade, estímulo à atividade biótica no mesmo e cobertura vegetal; policultura e consórcio entre plantas; manutenção do microclima por meio da otimização de elementos como radiação solar, vento e corpos d'água; além da sinergia entre os componentes da biodiversidade (CAPORAL, 2006, p. 13). Diversos estudos concluem que a diversificação dos sistemas agrícolas apresenta maior produtividade, pois o cultivo conjunto ${ }^{9}$ reduz a incidência de pragas e doenças por conta da diversidade genética, além de proporcionar um uso mais eficiente dos recursos naturais (ALTIERI, 1999, p. 19). Segundo Altieri (1999, p. 167), a agricultura convencional pauta-se apenas na produtividade da lavoura baseada exclusivamente em problemas como o fornecimento de nutrientes às plantas e o controle químico de pragas e doenças. Entretanto, para a agroecologia o controle de pragas não deve ser combatido com venenos e herbicidas, mas

\footnotetext{
${ }^{9}$ Por exemplo, o consórcio entre milho, feijão, abóbora, batata e feno (ALTIERI, 2010)
} 
sim pela compreensão das causas do desiquilíbrio ecológico indicadas pela existência de agentes patógenos, as quais podem ser reparadas e prevenidas com práticas que não agridam ainda mais o ambiente.

Com efeito, a grande inovação da ciência agroecológica não se relaciona apenas com o manejo agrícola, mas sim pelo fato de agregar, em uma matriz interdisciplinar, os saberes tradicionais acerca da cultura da terra. Afinal, a degradação ambiental não é uma questão apenas da ecologia em bases naturais, pois a cultura humana e o direcionamento que está sendo orientado para construção da civilização são protagonistas deste processo. Por este motivo, a agroecologia procura apresentar-se de forma reflexiva como um novo paradigma para o desenvolvimento rural e de agriculturas, assim procurando renovar as bases epistemológicas da existência humana (CAPORAL, 2006, p. 07). Contudo, a valorização do equilíbrio humano-natureza para além da produtividade, trouxe à problemática agrícola uma relação de diálogo que, através do intercâmbio de saberes tradicionais e científicos, transforma o desenvolvimento rural e de agriculturas em um processo social (ALMEIDA, 2009, P. 60). Como consequência, a extensão rural, a assistência técnica e a capacitação com princípios agroecológicos não devem ser resumidas em práticas de adestramento para a produção (CAPORAL, 2006, p. 16), pois o sistema de produção deve objetivar a autonomia e o engajamento por meio de transferência de tecnologias socialmente apropriadas.

Contudo, as grandes questões ambientais na sociedade brasileira, até mesmo de cunho existencial, baseiam-se na maneira com que a lógica da produção explora todo o território de um país que comporta uma verdadeira fonte de biodiversidade ainda preservada. Como exemplo, existem as gigantescas explorações de cana-de-açúcar que invadem o Estado de São Paulo e dedicam-se a encher tanque de automóveis, mudando drasticamente o microclima e ocasionando calor excessivo e secas que atingem a população das cidades próximas (ALTIERI, 2010). O modelo convencional agrícola, além de não agregar valor social e ambiental, traz impactos negativos à saúde pública, à integridade dos ecossistemas, à qualidade dos alimentos e exonera o agricultor que coloca as mãos na terra dos benefícios da produção. 


\subsection{AS CULTURAS DA TERRA}

As demais vertentes baseadas no cultivo agrícola ecológico diferenciam-se da ciência agroecológica porque propõem princípios e formas de manejo estruturadas não apenas em bases científicas, mas também em preceitos de seus criadores. Estas linhas constituíram-se no início do século XX, período em que os avanços científicos da agroquímica passaram a difundir o conhecimento acerca da adubação mineral, opondo-se às práticas tradicionais de adubação orgânica. Contudo, os movimentos contestadores tiveram como ponto de partida a valorização do solo e sua fertilidade por meio de componentes orgânicos. Deve-se destacar que, embora existam percussores e marcos históricos, o cultivo harmonizado com o ambiente faz parte do conjunto de saberes tradicionais de diversos povos, especialmente, indígenas. Porém, estes movimentos que vêm sendo estudados constituem-se como práticas de cultivo que dialogam com saberes tradicionais, mas trazem inovações modernas e científicas que, muitas vezes, são regulamentadas por normas que pouco assemelham-se ao manejo tradicional.

A agricultura biodinâmica originou-se na Antroposofia, a qual constitui uma vertente de pensamento fundada pelo filósofo austríaco Rudolf Steiner (1861-1925). Os fundamentos do Curso Agrícola Biodinâmico foram trazidos por Steiner, em 1924, a um conjunto de agricultores que passavam por uma grave crise em suas lavouras. Com efeito, uma série de princípios da Antroposofia, especialmente baseados na leitura fenomenológica do mundo descrita pelo naturalista Johann Wolfgang von Ghoete (17491832), convergiram com práticas desempenhadas no cotidiano da lavoura como a valorização da observação dos movimentos naturais sem a interferência da racionalidade; a constante experimentação prática do manejo como resultado mais relevante que técnicas científicas indutivas; a leitura das polaridades da natureza, como exemplo, a oposição entre fotossíntese e respiração, a sombra e a luz, a expansão e a contração entre outros.

Um dos princípios mais enfatizado por Steiner (1924) é a compreensão da propriedade agrícola como um organismo que constitui uma individualidade autossuficiente, pois uma propriedade equilibrada consegue produzir todos os insumos agrícolas necessários para seu desenvolvimento. O órgão vital deste organismo é o solo, o 
qual deve ser vivificado pelos componentes orgânicos que promovem a fertilidade do mesmo, assim garantindo o crescimento e o fortalecimento da produção. Steiner direciona o foco da atenção para a qualidade do solo e não apenas para as plantas e seus nutrientes, ampliando o olhar para além da produção. Contudo, o organismo agrícola biodinâmico deve ser equilibrado de acordo com os reinos da natureza mineral, vegetal em interação com o animal, além da necessidade de haver o trabalho humano e uma interação com a força do cosmos. Segundo Steiner, "tudo que está sobre a Terra é, de fato, apenas um reflexo do que se passa no Cosmos" (STEINER, 1924, p. 33). Por este motivo, o manejo biodinâmico apoia-se no calendário astronômico organizado por Maria Thum, no qual verifica-se a influência dos movimentos lunares e das constelações nos ciclos da lavoura.

Na atualidade, o selo de certificação de produção biodinâmica é um dos mais fortes no mercado, principalmente o selo internacional Demeter. Este nasceu da cooperativa fundada em 1934 que reuniu os agricultores que começaram a aplicar os princípios e práticas da agricultura biodinâmica. Contudo, para se obter a certificação biodinâmica, no Brasil concedida pelo IBD (Instituto Biodinâmico) localizado no município de Botucatu, deve-se seguir normas rigorosas como: a completa isenção do uso de agrotóxicos e adubos minerais, além da aplicação periódica de preparados biodinâmicos na produção agrícola.

Os preparados biodinâmicos são suplementos elaborados a partir de plantas medicinais, esterco e silício (quartzo), os quais são envoltos em órgãos de animais que são enterrados no solo até sua maturação e, em seguida, diluídos em água por meio de um processo chamado dinamização ${ }^{10}$. Os preparados atuam por meio dos elementos químicos $\mathrm{Si}, \mathrm{Ca}, \mathrm{K}, \mathrm{S}, \mathrm{Fe}, \mathrm{P}$ e têm como função auxiliar nos processos formativos do solo e das plantas, intensificar propriedades organolépticas ${ }^{11}$, auxiliar na estruturação interna e externa das plantas, conduzir o processo de fermentação e decomposição da

\footnotetext{
10 Movimento de agitação contínua de um certo volume de água, com uma medida de preparado biodinâmico já maturado e diluído, que tem como finalidade transmitir informações do princípio ativo à água. Este procedimento é realizado de forma similar com medicações homeopáticas.

11 As propriedades organolépticas são aquelas que podem ser apreendidas através dos sentidos como sabor, cheiro, cor, textura etc.
} 
compostagem, e proteger contra pragas e doenças. Alguns preparados são pulverizados no solo e nas plantas, e outros inoculados em adubos orgânicos. Steiner (1924) argumenta que os princípios ativos dos vegetais como a casca do carvalho e a flor da camomila são vivificados ao serem enterrados com órgãos de animais e sofrem influências dos ritmos sazonais da terra. Contudo, não cabe à presente pesquisa científica validar ou não este procedimento tão peculiar, porém, deve ser ressaltado que, principalmente na Europa, existe um grande mercado de produtos certificados biodinâmicos respeitado em escala mundial.

A agricultura orgânica é a denominação mais conhecida porque foi a forma de produção isenta de aditivos químicos que foi popularizada para o mercado consumidor. Esse movimento surgiu aproximadamente na década de 1930 por meio de estudos acerca da adubação orgânica realizados pelo inglês Sir Albert Howard, sendo disseminada na década de 1940 por Jerome Irving Rodale (EHLERS, 1999, p. 54). Com a crescente propagação do ambientalismo, a alimentação entrou na pauta das questões ambientais, sobretudo, por conta dos usos de venenos e adubos sintéticos. Este movimento foi difundido mundialmente pela organização de produtores rurais IFOAM (Federação Internacional de Movimentos de Agricultura Orgânica), a qual reuniu diversas vertentes de produção agrícola que realizavam uma produção saudável com cultivos diversificados e orgânicos, a fim de fortalecer o papel político deste tipo de produção.

O mercado orgânico apresenta uma série de normas que são acompanhadas por um processo de certificação. Isto surgiu da necessidade de regulamentar a origem dos produtos isento de venenos e fiscalizar o cumprimento das normas de certificação, as quais incorporam, além da produção em si, a preservação ambiental e o cumprimento de legislação trabalhista. Existem diversos tipos de certificação brasileira que muitas vezes são fomentada de forma participativa entre certificadoras e os produtores locais. Entretanto, os altos custos da certificação e da adequação ambiental das propriedades por vezes apresenta-se como impeditivos para a certificação da unidade familiar e refletem no preço final do produto.

A produção orgânica vem sendo legitimada pelo consumidor e pelo poder público que criou uma Lei Federal ( $\left.{ }^{\circ} 10.831 / 2003\right)$ a fim de regulamentar essa prática em âmbito nacional. $\mathrm{O} 1^{\circ}$ artigo define o sistema orgânico no seguinte sentido: 
Considera-se sistema orgânico de produção agropecuária todo aquele em que se adotam técnicas específicas, mediante a otimização do uso dos recursos naturais e socioeconômicos disponíveis e o respeito à integridade cultural das comunidades rurais, tendo por objetivo a sustentabilidade econômica e ecológica, a maximização dos benefícios sociais, a minimização da dependência de energia não-renovável, empregando, sempre que possível, métodos culturais, biológicos e mecânicos, em contraposição ao uso de materiais sintéticos, a eliminação do uso de organismos geneticamente modificados e radiações ionizantes, em qualquer fase do processo de produção, processamento, armazenamento, distribuição e comercialização, e a proteção do meio ambiente.

Outra forma de manejo encontrada na área de estudos foi a agricultura natural que foi concebida em 1935 no Japão por Mokiti Okada, o qual criou uma religião que tem como princípio o estímulo à alimentação de qualidade respeitando o ambiente natural. Por este motivo, o manejo de suas lavouras não poderia usar agrotóxico, adubação sintética, compostos e nem mesmo arar a terra (EHLERS, 1999, p. 61). O discípulo Fukuoka também criou uma linha de agricultura natural própria. $\mathrm{Na}$ área de estudo existe orientações técnicas acerca deste tipo de cultivo fomentado pela Igreja Messiânica que tem um grande templo e uma significativa produção nas proximidades da represa Guarapiranga, no bairro Jaceguava. Estes participam ativamente no processo de transição agroecológica, sendo proponentes de um projeto FEMA e comprando a produção orgânica da região.

A permacultura diferencia-se das demais vertentes porque é denominada como um sistema de design ecológico baseado em um planejamento sistêmico com tecnologias que harmonizam as necessidades antrópicas ao ambiente natural. De acordo com um de seus fundadores David Holmgren:

A permacultura não se resume apenas à paisagem, ou mesmo às técnicas da agricultura orgânica, ou às formas de produção sustentáveis, às construções eficientes quanto ao uso de energia, ou ao desenvolvimento das ecovilas, mas ela pode ser usada para projetar, crias, administrar e aprimorar esses e todos outros esforços feito por pessoas, famílias e comunidades em busca de um futuro sustentável (HOLMGREN, 2007, p. 03). 
Contudo, mesmo não se tratando especificamente de um sistema de produção agrícola, a permacultura é citada na Lei de Orgânicos porque é uma forma de cultura permanente que apresenta um conjunto de técnicas que manejam o ambiente natural.

O ecologista australiano Bill Mollison em 1974, juntamente com o ecologista David Holmgren, foram percursores deste sistema. Para estes, o planejamento permacultural pode criar um ambiente saudável, com energia suficientemente armazenada e recursos em abundância que são aproveitados para não causar desperdícios. Para este efeito, deve-se compreender que a propriedade agrícola é composta de elementos como a casa, os corpos d'àgua, o galinheiro, a horta, os quais devem ter suas multifunções conectadas. Como exemplo, a água dos peixes de um tanque pode ser utilizada para regar o jardim, pois contém matéria orgânica rica em nutrientes. A fim de otimizar a sinergia destes elementos, é necessário estabelecer que quanto maior a diversidade de elementos, mais estabilidade terá o sistema; também é necessário pensar os elementos no espaço de acordo com sua função para economizar energia, pois o problema gerado pode ser a solução do mesmo. No Brasil o australiano Peter Webb é a referência dos estudos de permacultura e ministra uma série de cursos de tecnologias ecológicas como: filtros biológicos, técnicas de bioconstrução, tratamento de água e esgoto, teto verde, banheiro seco, horta mandala, compostagem entre outros. Abaixo imagens de tecnologias ecológicas encontradas na área de estudos:

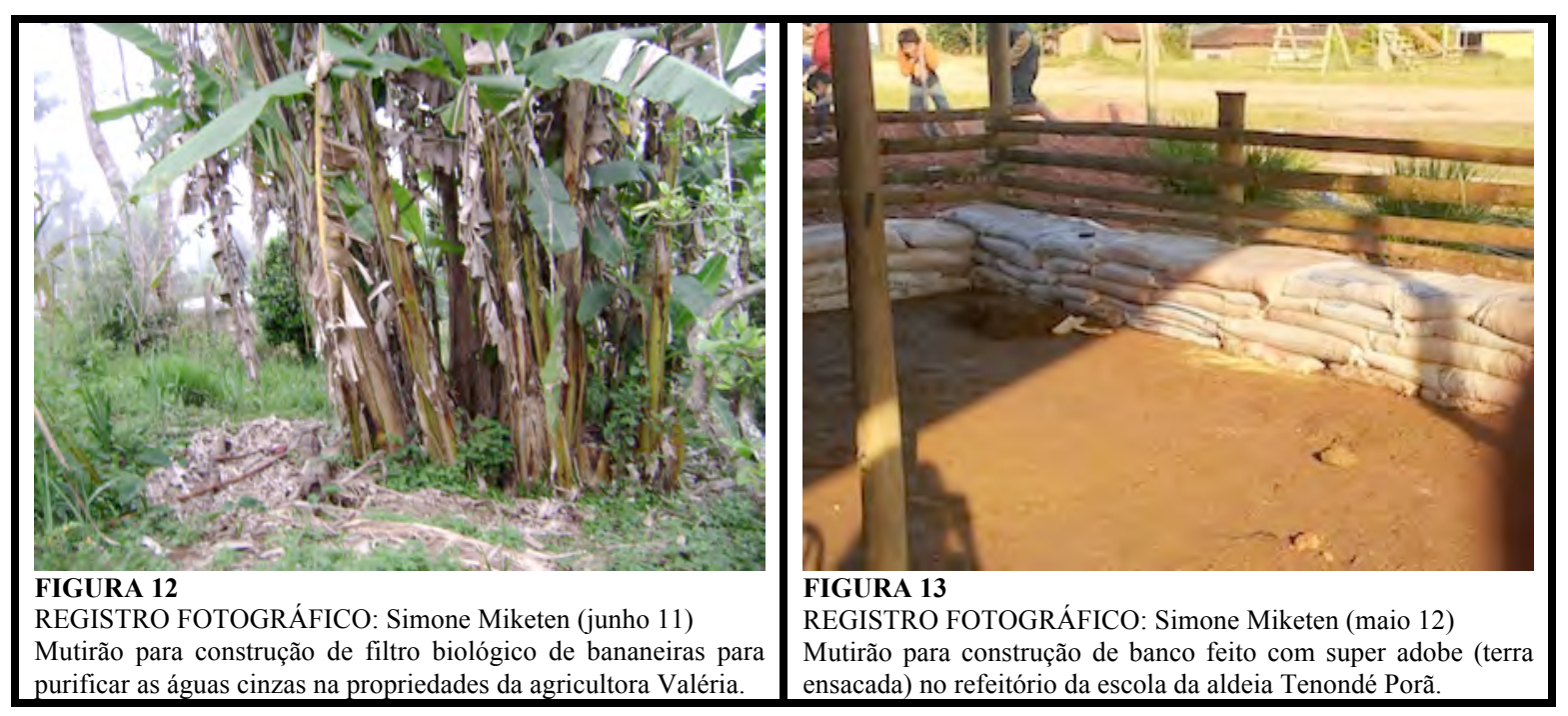




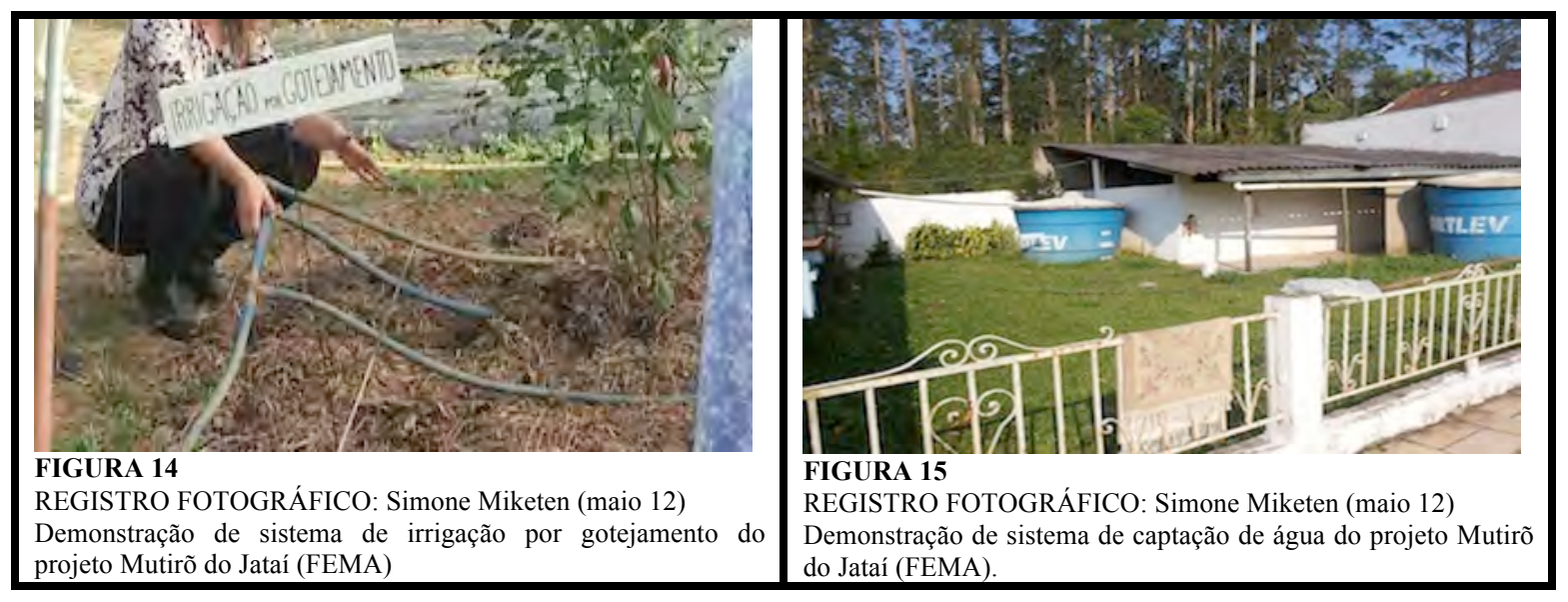

O sistema agroflorestal (SAF) ou a chamada agrofloresta consiste no manejo consorciado entre diversas espécies de diferentes substratos, visando o aproveitamento do espaço e seus recursos como luz e água. O maior objetivo é construir uma floresta produtiva de acordo com os processos de sucessão ecológica. O pesquisador suíço Ernest Götsch é a grande referência no Brasil em estudos e práticas de SAF. Os maiores beneficiamentos deste sistema de cultivo é a recuperação de ecossistemas apoiados em processos naturais florestais em conjunto à produção de alimentos. Contudo, práticas tradicionais, especialmente indígenas, cultivam sob desenhos de agrofloresta criando microclimas estáveis protegidos do vento e da insolação, além de um solo fértil e úmido (CAPORAL, 2006, p. 13).

\subsection{O MANEJO DA BIODIVERSIDADE}

As diversas noções e conceituações dissertadas ao longo do capítulo trouxeram, em bases teóricas, a relação inerente entre a atividade agrícola e o ambiente natural. Combinação que, por vezes, gera uma série de confusões e conflitos porque a atividade em si confunde-se com o próprio ambiente. Esta grande complexidade transborda para a esfera da administração pública e reflete no grande descompasso existente entre a realidade dos cultivadores da terra, a regulamentação de sua atividade econômica e a ordenação de seu território. Por este motivo, a agricultura em bases agroecológicas deve, cada vez mais, ganhar novas dimensões que associem as necessidades das vozes do campo às inovações das vozes da cidade, assim fazendo com que o manejo agrícola seja compreendido como fonte de alimentos de qualidade associado ao cuidado da terra. 


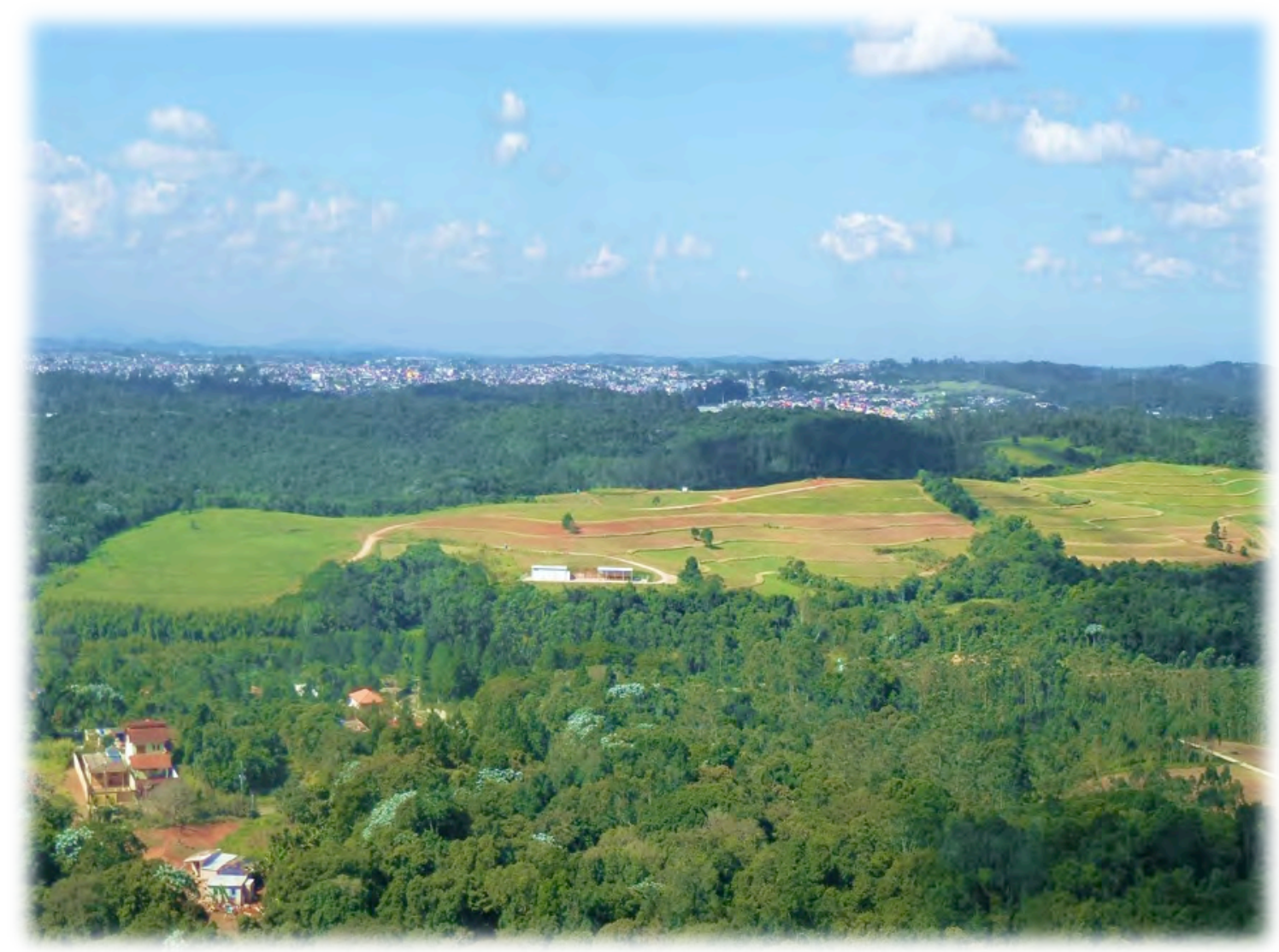

capítulo 2 - O CAMPO CITADINO 


\subsection{OS TRAÇOS PRIMEVOS DA PORÇÃO SUL PAULISTANA}

"Este lugar está situado de modo que é aformoseado pela mais agradável variedade de arvoredos, campos e pomares, através dos quais correm rios de chrystalinas águas".

José Bonifácio de Andrade e Silva ${ }^{12}$

Estas palavras do poeta, naturalista e estadista José Bonifácio de Andrade e Silva referenciam o sertão verde paulistano nos idos de 1820, o qual ligava a capital São Paulo ao litoral paulista por uma bela paisagem natural que pode ser apreciada até os dias atuais, principalmente, nas proximidades da Serra do Mar. Este cenário foi espaço de ocupação tardia e pouco consolidada, tendo seus traços primevos demarcados por indígenas que utilizavam aquela vasta região como uma área de passagem formando, assim, uma rede de caminhos nos fundo dos vales que conectavam o litoral ao interior (ZENHA, 1977, p. 57). Traçados, estes, que mais tarde foram apropriados por jesuítas e colonos e, mais recentemente, influenciaram até mesmo o percurso do sistema viário urbano.

Estas trilhas marcavam caminhos que interligaram as aldeias Ibirapuera e Itanhaém, as quais mais tarde virariam vilas coloniais passando para as alcunhas de Santo Amaro do Ibirapuera e Conceição do Itanhaém. Devido ao aumento de colonos europeus, em 1686 instaurou-se a Freguesia de Santo Amaro que tinha a agricultura como principal atividade econômica. Em poucas décadas, a chegada de escravos negros provenientes da mineração reforça a mão-de-obra na lavoura e nos serviços doméstico, assim elevando Santo Amaro à categoria de município em 1832 (ZENHA, 1977, p. 117). Muitas das características da área de estudo são formadas a partir da história deste antigo município, o qual até 1935 abarcava toda a área que iria da atual Igreja Matriz de Santo Amaro até a Serra do Mar, diferentemente dos limites administrativos do atual bairro de Santo Amaro.

${ }^{12}$ (ZENHA, 1977, p. 57). 


\section{ESPACIALIZAÇÃO DO MUNICÍPIO DE SANTO AMARO}

“Os limites do município aparecem pela primeira vez no relatório do Dr. Nabuco de Araújo, apresentado em 1852: 'com a freguesia da Sé, pelo Ribeirão da Traição acima, desde o ponto que atravessava a estrada até as suas primeiras vertentes e daí seguindo até chegar a Cruz das Almas, na estrada dos carros, a buscar o sítio do Capitão André Cursino e daí a rumo do Sul, pela estrada que vai ao sítio de Antônio Medeiros, no Curral Grande, seguindo a estrada dos carros até a encruzilhada de Pinhaíba, onde se toca com a reta que, seguindo pelo Morro Vermelho, divide a Sé da freguesia de São Bernardo. Com São Bernardo divide-se caminhando pela estrada do Guacuri, na ponte e córrego, a dar no rio Jurubatuba, e por ele a dar no Rio Grande, onde faz barra o Rio Pequeno, e daí em linha reta, à Serra do Mar. Com Santa Efigênia e Cotia, pelo ribeirão da Traição abaixo até fazer barra com o rio dos Pinheiros, e atravessando este a rumo direito a procurar a encruzilhada do caminho que vai da cidade de São Paulo a M'Boi, até encontrar o rio M'Boi Mirim. Com Itapecirica seguindo da ponte que fica no caminho mencionado, rio abaixo até outra ponte do M’Boi Mirim, no caminho de Bouguassu, e por ele a ponte do Jasseguava e desta ponte, rio acima, até as suas nascentes, e daí, em linha reta, até a Serra do Mar, pertencendo a Santo Amaro os moradores que lhe ficam aquém da Serra.

FIGURA 16 - Espacialização município de Santo Amaro FONTE: (BERARDI, 1981, p. 68).

Neste contexto, a consolidação efetiva do primeiro povoamento na área ocorreu apenas em 1830 com o assentamento de imigrantes alemães em uma peculiar localidade que dista cerca de trinta e cinco quilômetros do centro de São Paulo. A singularidade deste local está no fato de se encontrar uma feição geomorfológica formada pelo choque de um meteoro que ocorreu a cerca de 35 milhões de anos (BELLENZANI, 2000). Ao avistá-lo, percebe-se que as edificações atuais foram construídas em uma verdadeira cratera.

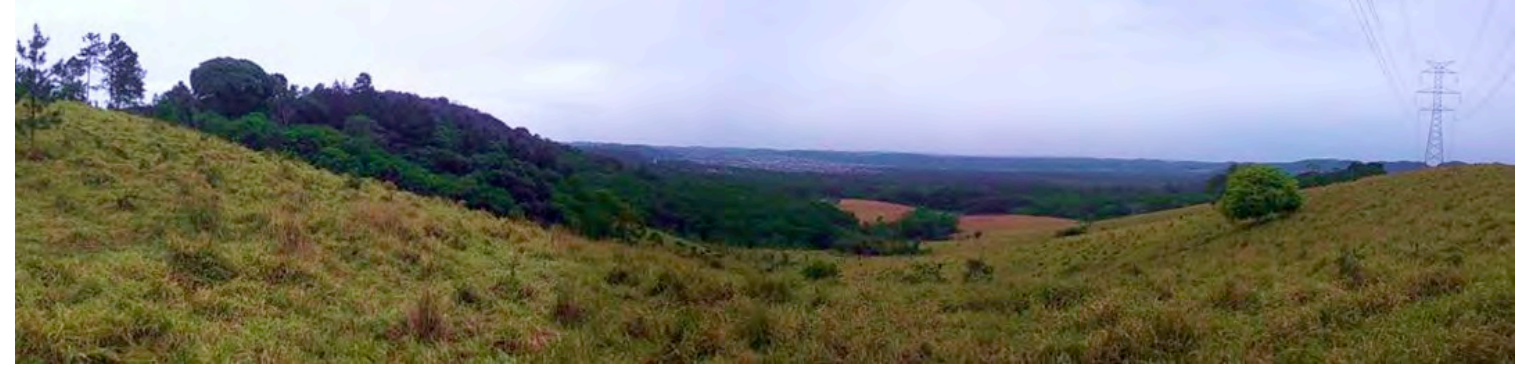


A Colônia Alemã foi estabelecida na região pelo Ministro do Império Brasileiro José Bonifácio de Andrade e Silva. Por determinação da Coroa do Império Brasileiro, havia a necessidade de assentar cerca de duzentos imigrantes alemães em terras brasileiras fruto de acordo com países europeus. A escolha do local deveria ser estratégica porque este grande contingente de colonos não tinha obrigações com a Coroa Brasileira e nem mesmo com a Constituição Nacional, sendo necessário escolher uma área isolada, pouco povoada e com condições ambientais para realizar atividades agrícolas (BERARDI, 1981, p. 65). A região entre os ribeirões Colônia e Vermelho foi disponibilizada para a chegada da Colônia Alemã porque cumpria o requisito de isolamento.

A característica de abandono será a marca deste processo de ocupação em todos os sentidos, pois este empreendimento de custo elevado não foi ancorado por uma política de colonização, assim gerando uma grande crise de adaptação aos imigrantes germânicos. No lugar do desenvolvimento de uma vila, ou mesmo uma cidade, já nos primeiros anos o retrato da Colônia Alemã era de meia dúzia de ranchos pobres e um cemitério protestante, difundidos em uma grande área (BERARDI, 1981, p. 56).

As características do relevo da região também dificultaram o estabelecimento dos colonos, pois se trata de planícies aluviais com terrenos alagadiços de dificuldade de drenagem por conta da baixa declividade e nível freático próximo à superfície. Estas características dificultaram a ocupação e o desenvolvimento da atividade agrícola rudimentar (SÃO PAULO, 2004, p. 24). Houve uma grande dispersão dos colonos pela região em busca de terrenos mais propícios ao cultivo de hortaliças, assim possibilitando uma grande miscigenação com os nativos que ali habitavam de forma dispersa. Aos poucos a cultura germânica foi perdendo muitos aspectos de seus traços tradicionais (ZENHA, 1977, p. 114), porém é possível notar os traços étnicos no cruzamento ainda visível de cabelos loiros, olhos azuis à pele morena e às feições caboclas. "Os alemães em nada se diferenciavam dos caboclos: esqueceram o eisbem ${ }^{13}$, os cremes de leite, os choucrouts, e se alimentavam de feijão, farinha e palmito que iam buscar no mato" (BERARDI, 1981, p. 57). Mesmo com tantas intempéries, os alemães não deixaram de lavrar a terra aumentando consideravelmente os gêneros alimentícios da região,

\footnotetext{
${ }^{13}$ Prato típico da culinária germânica que tem como ingrediente joelho de porco.
} 
principalmente, a produção de babatas tipicamente germânica. Em poucas décadas Santo Amaro torna-se o "celeiro da capital" abastecendo São Paulo, principalmente, pela produção de arroz, feijão, milho, mandioca e batata (BERARDI, 1981, p. 72).

\subsection{SANTO AMARO, PADROEIRO DOS AGRICULTORES}

Impulsionado pelas atividades agrícolas em contínuo destaque na região, Santo Amaro integra o chamado "Cinturão Caipira" (CARVALHO, 2005), assim constituindo a área rural localizada no entorno da capital São Paulo. As terras eram as menos férteis da região com muitas áreas alagadiças, porém Santo Amaro era o principal fornecedor de alimentos produzindo também chá, café, algodão, fumo, frutas, cachaça proveniente da cana-de-açúcar, além da criação de gado e sobretudo cavalos (SAINT-HILAIRE ${ }^{14}$ apud FERNANDES, 1976, p. 184).

Relatos apontam que a atividade agrícola era bastante rudimentar, porém resguardava a vida simples sem sofrer tantas pressões culturais.

Reinava a maior primitividade de métodos entre aqueles lavradores, que só entendiam plantar roças em terra de mata virgem. Por esse motivo, em busca de mata virgem, afastavam-se cada vez mais dos centros civilizados e, perdidos na solidão, embruteciamse. Cada vez mais se alongavam tais distâncias, pelos processos de agricultura nômades, sempre em busca de terras novas e frescas". (...) "Dois vícios ainda mais poderosos empobrecem este povo: presunção e preguiça. Não fazem nada; de dia e de noite estão deitados ou balançando nas redes, ou cachimbando, e é tal a sua vaidade que têm desprezo pelo trabalho, entre eles não há mãos que abrem, senão a dos pretos. Quem não tem escravos perece, porque não tem quem the ganhe ou lhe procure de comer. A ociosidade era flagelo tanto maior quanto atingia terras escassamente povoadas (BERARDI, 1981, p. 50).

Contudo, por toda vasta região, onde os colonos alemães e seus descendentes se espalharam, existiu um comportamento mais aberto a inovações, sendo estes responsáveis por várias ações ligadas à ideia de progresso como: a abertura do caminho ${ }^{15}$ por Parelheiros até a Serra do Mar, hoje sendo a principal via de acesso com o nome do

${ }^{14}$ SAINT-HILAIRE, A. Viagem à Província de São Paulo: 1779-1853. São Paulo: Itatiaia, 1976.

${ }^{15}$ Iniciativa de Henrique Schunck, segundo versão relatada pela família (ZENHA, 1977, p.23). 
lenhador japonês Sadamu Inoue; fundaram vilas (Cipó e Parelheiros); foram pioneiros em relação ao uso de luz elétrica (SÃO PAULO, 2011, p. 38) e também povoaram as regiões de Gramado, Cipó, Casa Grande e Bororé espraiando-se por chácaras (ZENHA, 1977, p. 42). Outro fator que contribuiu para o desenvolvimento da região foi a presença de jazidas de minérios de ferro que, mesmo tendo qualidade inferior, era usado para confecção de ferramentas agrícolas (BERARDI, 1981, p. 30). A influência alemã expandiu-se por toda parte através dos nomes de origem germânica que estão nas principais vias como Guilguer, Hessel, Heimberg entre outros.

Outros imigrantes vieram para a região no final do século XIX e início do século XX como portugueses, árabes, russos, turcos, ingleses e estadunidenses ocupando cargos no comércio e na indústria que cresciam no município de Santo Amaro. Especialmente após a Segunda Guerra Mundial, os japoneses ${ }^{16}$ povoaram a região (SÃO PAULO, 2004) demarcando sua presença em nome de vias e na preservação de diversos costumes culturais. Sua dedicação às práticas agrícolas são percebidas nos cuidadosos desenhos geométricos de seus canteiros e no primoroso arranjo de suas propriedades com a utilização de técnicas de jardinagem.

A área de estudo tem sua memória, ainda desenhada em sua paisagem nos dias de hoje, germinada em bases rurais tradicionais manipuladas por técnicas agrícolas de caboclos, indígenas e imigrantes de predominância alemã e japonesa. Uma ruralidade com sensação de umidade ora emergente das nascentes e rios que acompanham todo relevo, ora soprada pela neblina do mar que surpreende nas manhãs e no fim das tardes. Muitos seres humanos caminharam dias entre o vazio de seu sertão e a exuberância de uma Mata Atlântica até hoje preservada, além de água à disposição sempre brotando em abundância. Até meados do século XIX a região servia como um local de passagem pelo privilégio de ter sua localização entre a escarpa da Serra do Mar e a planície já ocupada.

\footnotetext{
16 Atualmente grandes produtores da região descendem destes imigrantes nipônicos e existe uma série de instituições religiosas japonesas na localidade como o gigantesco templo da Igreja Messiânica fundada pelo líder espiritual Mokiti Okada, o qual também funda a linha da Agricultura Natural.
} 


\subsection{OS TRILHOS DA URBANIZAÇÃO}

A cidade de São Paulo foi expandindo-se pelos eixos fluviais ao longo do rio Tietê e seus principais afluentes Anhangabaú, Tamanduateí, Pinheiros, Cabuçu, Pirajussara entre outros. Dentre esta dinâmica expansionista, o município de Santo Amaro reservou o espaço ambientalmente ideal para o desenvolvimentismo do município de São Paulo, sendo anexado em 1935 à capital paulista. Esse tipo de conurbação que segundo Villaça (2001, p. 51) é um "processo devorador de cidades e produtor de bairros", causa consequências diretas nas propriedades dos 'caipiras' alemães e caboclos do antigo município de Santo Amaro que, com o solo esgotado pelo roçado e o aumento dos impostos territoriais, começam a dividir seus sítios em loteamentos dando lugar ao aparecimento de vilas (BERARDI, 1981, p. 114). A demarcação de loteamentos e a expansão imobiliária afastam as unidades de produção agrícolas para áreas distantes, restando uma pequena parcela de agricultores que resistiram ao processo em uma nova configuração espacial da área. A pacata e rudimentar vida rural agitava-se, sendo sobreposta pela invasão territorial do crescimento industrial e urbano.

A expansão da capital, em direção à sua nova porção sul administrativa, foi facilitada pela ampla geomorfologia e a paisagem natural do local (BERARDI, 1981, p. 114). Isto impulsionou a construção de grandes estruturas de lazer, residências operárias e também de alto padrão, loteamentos industriais, além dos projetos de abastecimento hídrico e de energia elétrica da cidade por conta da abundância de água na região. Uma série de gigantescas obras de infraestrutura são construídas na área como, em 1907, o grande reservatório hídrico Guarapiranga com área de drenagem de 63.911 ha; a linha de bonde para a capital em 1900 que substituiu a antiga estrada de ferro; outro reservatório hídrico em um projeto ainda mais ousado denominado pelo nome do engenheiro responsável Billings em 1926; a Autoestrada Washington Luis para tráfego de automóveis, sinalizando o progresso e facilitando a consolidação de residências de alto padrão ao longo de seu percurso; o aeroporto de Congonhas; o Autódromo de Interlagos em 1930; a expansão de ramais ferroviários para transporte de mercadorias e pessoas (SÃO PAULO, 2011). 


\subsection{O MOSAICO DO AMBIENTE}

Dentro do cenário exposto acima, os anos 1990 trouxeram uma nova leitura do espaço da zona sul da capital, especialmente, no que tange à esfera ambiental. O mosaico de territórios circunscritos pela temática de conservação ambiental ganha cada vez mais contornos por meio de normatizações institucionais, sobretudo, devido à necessidade em caráter de urgência de viabilizar a qualidade dos recursos hídricos para abastecer a cidade de São Paulo. Frente à crescente eutrofização e poluição dos reservatórios hídricos, o controle ambiental torna-se mais austero e legitimado, especialmente nas áreas de mananciais. Um dos principais marcos legais é a criação da Lei de Crimes Ambientais (Lei Federal $\mathrm{n}^{0}$ 9.605/1998), fomentando a fiscalização ambiental, e também o fortalecimento do ambientalismo após a Conferência das Nações Unidas sobre Meio Ambiente e Desenvolvimento (CNUMAD) conhecida como ECO-92 (SANTORO, 2012, p. 97).

Estes perímetros objetivam constituir-se como unidades de gestão e planejamento $^{17}$ socioambientais apresentando interfaces com as atividades agrícolas e as estratégias de conservação ambiental. As unidades estão dispostas em espaços que se sobrepõem, formam mosaicos, redes e uma variante de conformações, as quais se enleiam de forma maleável trazendo uma grande complexidade no entendimento da área de estudo, especialmente, por não respeitarem limites apenas físicos ou administrativos.

A urbanização é um elemento crescente nestes espaços, pois o aumento da população do município e da escassez da oferta de terras urbanizáveis em áreas centrais, resulta na ocupação de áreas periféricas com potencial ambiental. O congelamento da ocupação antrópica nas áreas de mananciais da porção sul do município deve ser pautado em estratégias socialmente inclusivas, ponderando a conservação ambiental prioritária com a existência de moradores que se estabeleceram nestas áreas, muitas vezes, impelidos pelos altos preços dos loteamentos em áreas centrais.

\footnotetext{
${ }^{17}$ Os termos gestão e planejamento muitas vezes são tratados como sinônimos, principalmente pelo desgaste da menção ao planejamento público e ideia de inovação no termo gestão. Porém, planejamento refere-se ao plano futuro de ação enquanto gestão é a efetivação da administração no momento presente (DEUS \& BRITO, 2009)
} 
Contudo, a manifestação de problemas ambientais demandam estratégias baseadas em abordagens multidisciplinares, pois a construção de soluções, frente à alarmante condição ambiental na região, reside em problemas sociais enredados por natureza na tamanha complexidade socioespacial da área. Para Hannigan, os problemas ambientais apresentam similaridade com os problemas sociais, porém, apesar de emergir das necessidades antrópicas, os problemas ambientais trazem consigo uma base física mais contundente, muitas vezes, sendo iluminados por descobertas científicas. As questões levantadas para além de argumentos morais, os quais normalmente são a base de problemas sociais, aliadas à dimensão física e à chamada comprovação científica criam um campo de legitimação da sociedade que rebate na construção de políticas públicas (HANNIGAN, 2009, p. 99). Por este motivo, a inserção de problemas ambientais na agenda de políticas públicas devem estabelecer dimensões integradas. Estes aspectos multidisciplinares têm como pano de fundo o processo de produção do espaço urbano. A qualificação da terra depende do valor de sua localização e, por este motivo, a análise investigativa da produção do espaço desvela a própria produção da sociedade abrangendo sua diversidade de aspectos que determinam a relação dos indivíduos com a estrutura urbana. As diferentes unidades de gestão e planejamento ambientais serão elencadas a seguir:

\subsection{1. ÁREAS DE PROTEÇÃO E RECUPERAÇÃO DE MANANCIAIS}

Nos anos 1970, as consequências da expansão urbana começam a comprometer a sustentabilidade da própria cidade de São Paulo, pois a ocupação antrópica nas bacias das represas Guarapiranga e Billings vem gerando, até a atualidade, o comprometimento da qualidade hídrica de cerca de $30 \%$ do abastecimento da cidade. Por este motivo, o poder público inicia a criação de leis normatizadas por demandas ambientais e de proteção do território, assim objetivando a preservação dos recursos naturais, principalmente hídricos, por meio da criação das Leis Estaduais ( $n^{0} 898 / 1975$ e n ${ }^{0}$ 1.172/1976) para proteção das áreas de mananciais da Região Metropolitana de São Paulo (SÃO PAULO, 2008, p.111). 
CONCEITO MANANCIAIS

Os mananciais são nascentes, locais onde há concentração natural de água doce, originada de lençóis subterrâneos, e de águas superficiais, cuja preservação deriva de um sistema especial de proteção da vegetação. Nessas áreas, formam-se importantes ecossistemas, várzeas e brejos com vegetação adaptada às condições de encharcamento e com grande variedade de espécies animais.

FIGURA 18: Conceito mananciais FONTE: (BILLINGS, 2009)

A completa inoperância fiscalizatória dos órgãos públicos, frente à proteção deste território ambiental de baixa ocupação antrópica, abriu espaços para loteamentos irregulares, assim ocasionando o processo de ocupação urbana (SÃO PAULO, 2008, p. 137). Este cenário agravou o comprometimento da qualidade hídrica da região, assim fazendo emergir a necessidade da criação de uma nova Lei de Mananciais (Lei Estatual $n^{0}$ 9.866/1997), a qual ampliou as estratégias de preservação conjecturando não apenas a proteção, mas também a recuperação da qualidade ambiental dos mananciais para abastecimento público da cidade (SÃO PAULO, 2008, p. 133). A revisão da Lei de Mananciais dispõe de novos mecanismos como as estratégias para implantação, operação, e manutenção de efluentes líquidos e resíduos sólidos, anteriormente proibidos nas áreas; além de instrumentos para proteger áreas de preservação permanente (APPs) ${ }^{18}$ ocupadas irregularmente (SÃO PAULO, 2008, p. 188). Outras duas leis específicas: APRM-G (Área de Proteção e Recuperação Ambiental da Subbacia do reservatório Guarapiranga) (Lei Estatual n ${ }^{\circ}$ 12.233/2006) e APRM-B (Área de Proteção e Recuperação Ambiental da Subbacia do reservatório Billings) - (Lei Estatual $n^{\circ} 13.579 / 2009$ ) foram instituídas seguindo as diretrizes da revisão da Lei de Mananciais, porém trazendo características mais específicas de cada Subbacia respectivamente.

A gestão das APRMs conta com a integração da sociedade civil por meio do Comitê de Bacias, com participação paritária e de caráter deliberativo, pois a

\footnotetext{
${ }^{18}$ As Áreas de Preservação Permanentes (APPs) são áreas ambientalmente frágeis que necessitam de maior cuidado como topo de morro, encostas e mata ciliar de corpos d'água.
} 
concentração demográfica, crescente nas áreas de mananciais, foi um dos motivos que fez emergir a necessidade de enredar os atores locais na gestão e no planejamento destas áreas. Por este motivo, foram estabelecidos os Comitês de Bacias Hidrográficas que constituem ferramentas de gestão descentralizadas, os quais agregam a sociedade civil nos processos de tomada de decisões. Estes órgãos são colegiados tendo parcelas do Estado, do Município e da sociedade civil para a regulamentação da legislação, a fim de garantir a qualidade ambiental das APRMs.

A ordenação territorial das áreas de mananciais contou com a criação das Áreas de Intervenção, assim configurando uma das diretrizes mais importantes porque apontam para a adequação dos usos referente aos espaços, prevendo que devem utilizar não apenas parâmetros urbanos, mas agregando também os usos agrícola, de mineração, os campos antrópicos e a vegetação nativa (SÃO PAULO, 2002). Foram criadas três categorias de acordo com uso restrito, de ocupação controlada e de prioridade para recuperação. Sendo (1) Área de Restrição a Ocupação - ARO, integralmente protegidas por conta da importância ambiental para garantir a qualidade hídrica; (2) Área de Ocupação Dirigida AOD, de ocupação controlada; e (3) Área de Recuperação Ambiental - ARA, sendo espaços degradados. Deve-se destacar que estas são apenas indicações das características da área, pois apontam apenas diretrizes para o zoneamento municipal mais restritivo e detalhado (SÃO PAULO, 2006, p. 41). A competência de legislar sobre a localidade cabe ao município conforme previsto na Constituição Federal de 1988, no artigo 30, e no Estatuto da Cidade no capítulo 2, Seção I, artigo 4 (Lei Federal n ${ }^{\circ}$ 10.257/2001).

Os cronogramas de ações, nas áreas de mananciais, devem ser baseados em um Plano de Desenvolvimento e Proteção Ambiental (PDPA) que visa integrar políticas regionais e setoriais nas bacias hidrográficas, assim como adequação de infraestrutura e saneamento, especialmente, nas Perímetro da Recuperação de Interesse Social (PRIS), assim garantindo a qualidade ambiental integrada às necessidades dos moradores locais. Dois grandes eventos foram realizados para levantar as características e soluções para a região, sendo o Seminário Billings em 2002 e o Seminário Guarapiranga em 2006 que tem como um dos objetivos:

Incentivar as atividades compatíveis com a produção de água, para envolvimento e sustentação das comunidades que vivem na região e para prover a RMSP de outros serviços como os ligados ao lazer, turismo, agricultura urbana e periurbana, manejo 
florestal e agroflorestal (SÃO PAULO, 2006, p. 12).

Abaixo segue material cartográfico com a hidrografia do Município e a delimitação das Subbacias Guarapiranga e Billings: 


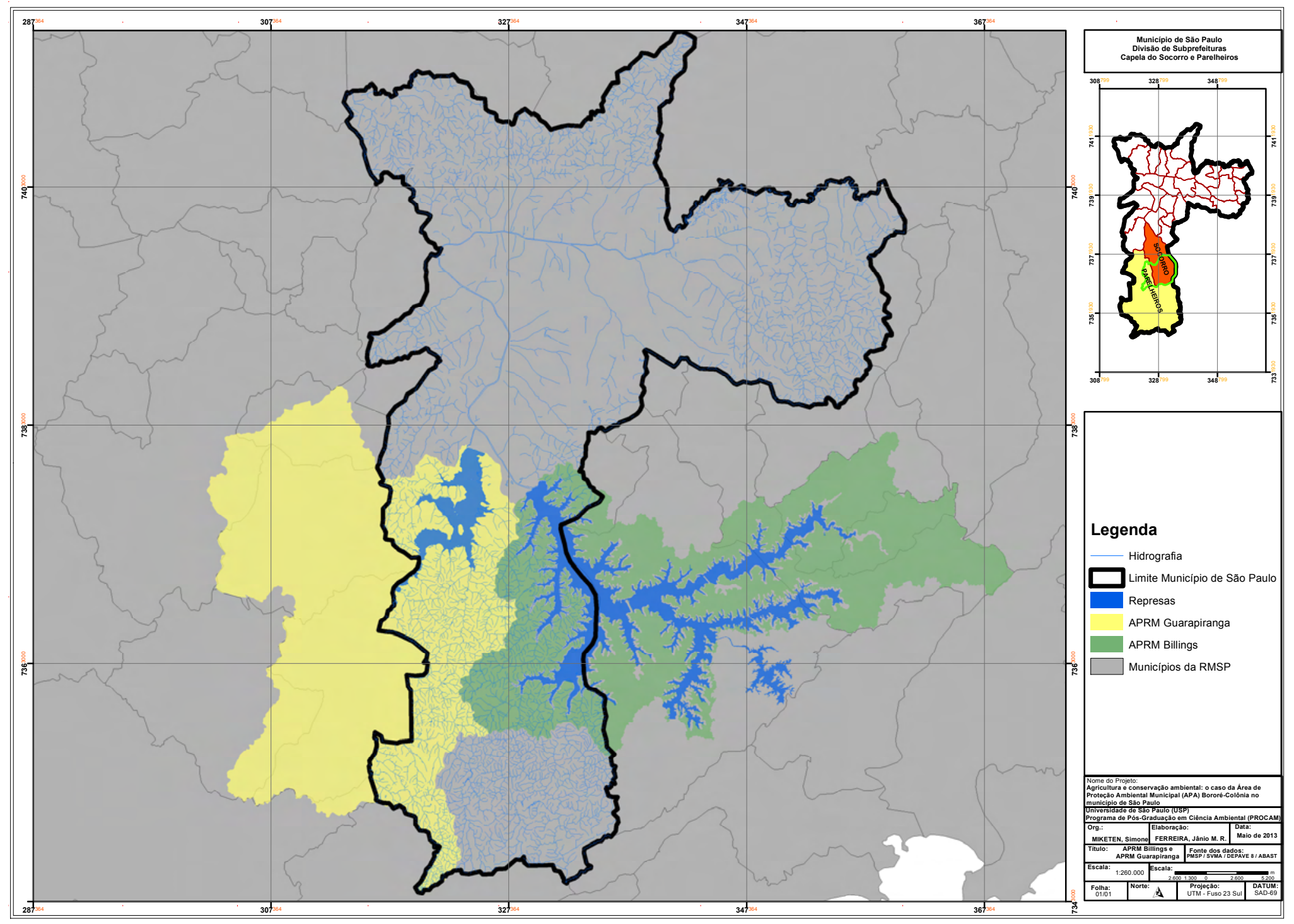




\subsubsection{RBCV - RESERVA DA BIOSFERA DO CINTURÃO VERDE}

A porção sul do município de São Paulo está inserida no conjunto de áreas com relevância ambiental que compõem a Reserva da Biosfera, denominada pelo Sistema Nacional de Unidades de Conservação - SNUC (Lei Federal n ${ }^{\circ}$ 9.985/2000) como um modelo de gestão que integra a preservação da biodiversidade e o desenvolvimento humano por meio de instrumentos de proteção e apoio a programas ambientais.

A Reserva é um centro de monitoramento, pesquisas, educação ambiental e gerenciamento de ecossistemas, bem como centro de informação e desenvolvimento profissional dos técnicos em seu manejo. Seu gerenciamento é o trabalho conjunto de instituições governamentais, não governamentais e centros de pesquisa. Esta integração busca o atendimento às necessidades da comunidade local e o melhor relacionamento entre os seres humanos e o meio ambiente.

FIGURA 19: Conceito Reserva da Biosfera

FONTE: http://www.mma.gov.br/reserva-da-biosfera

Na Região Metropolitana de São Paulo (RMSP) foi criada a Reserva da Biosfera do Cinturão Verde (RBCV) fortalecida pelo movimento de resistência popular nos anos 1980 que tardou a implantação da Via Perimetral Urbana hoje conhecida como Rodoanel, assim trazendo visibilidade à importância da conservação ambiental da região e seu valor humano, circundado um dos maiores aglomerados urbanos do planeta. O território das APAs Bororé-Colônia e Capivari-Monos fazem parte da Reserva da Biosfera do Cinturão Verde pelo fato de possuir importantes remanescentes de Mata Atlântica conjugados às áreas urbanas. A proximidade do contexto da cidade estimula desafios para implantação de ações que proporcionem a proteção da biodiversidade e a sustentabilidade do espaço urbano e periurbano. A RBCV abrange a Região Metropolitana de São Paulo, Baixada Santista e parte nas Regiões Administrativas de Campinas, Registro, São José dos Campos e Sorocaba; assim compreendendo 73 municípios e cerca de 23 milhões de habitantes (RODRIGUES, VICTOR \& PIRES, 2006). 
Segue abaixo a definição de Reserva da Biosfera que consta no Sistema Nacional de Unidades de Conservação - SNUC (Lei Federal nº 9.985/2000)

\begin{tabular}{|l|}
\hline \multicolumn{2}{|c|}{ LEI N $^{\mathbf{0}}$ 9.985, DE 18 DE JULHO DE 2000} \\
\hline SISTEMA NACIONAL DE UNIDADES DE CONSERVAÇãO DA NATUREZA - SNUC \\
\hline CAPÍTULO VI DAS RESERVAS DA BIOSFERA \\
Art. 41. A reserva da biosfera é um modelo, adotado internacionalmente, de gestão integrada, \\
participativa e sustentável dos recursos naturais, com os objetivos básicos de preservação da \\
diversidade biológica, o desenvolvimento de atividades de pesquisa, o monitoramento ambiental, a \\
educação ambiental, o desenvolvimento sustentável e a melhoria da qualidade de vida das populações. \\
§ 5o A reserva da biosfera é reconhecida pelo programa intergovernamental "o homem e a biosfera - \\
mab", estabelecido pela UNESCO, organização da qual o Brasil é membro. \\
\hline FIGURA 20: SNUC \\
FONTE: http://www.planalto.gov.br/ccivil_03/leis/L9985.htm
\end{tabular}

Mesmo diante ao forte movimento de resistência, o supracitado anel viário Rodoanel Mário Covas iniciou suas obras em 2002 pelo trecho oeste. Executado pela empresa DERSA, sob jurisdição estadual, a obra foi planejada para ser um gigantesco anel viário circunscrito à cidade de São Paulo, sendo caracterizado no Trecho Sul como uma via "Classe Zero", ou seja, em seu traçado não constaria acesso dentro da cidade, apenas existiriam entroncamentos interligando rodovias com o objetivo de retirar o fluxo de caminhões na circulação interna da cidade. Com efeito, esta via apenas atenderia a circulação de mercadorias e melhorias ao trânsito das áreas centrais do Município, utilizando espaços periféricos da cidade como passagem, sem nenhum benefício direto à infraestrutura viária destes trechos.

Em 2009 foi inaugurado o Trecho Sul do Rodoanel em uma área de grande fragilidade ambiental e social que compreende as Subprefeituras de Parelheiros e Capela do Socorro. Seu traçado suprimiu centenas de hectares de remanescentes de Mata Atlântica, em sua maioria, dentro do perímetro da APA Bororé-Colônia, além de impactar diretamente a área de mananciais e as bacias hidrográficas das represas Billings e Guarapiranga, formando um enorme viaduto que transpassa as águas de ambas represas. 

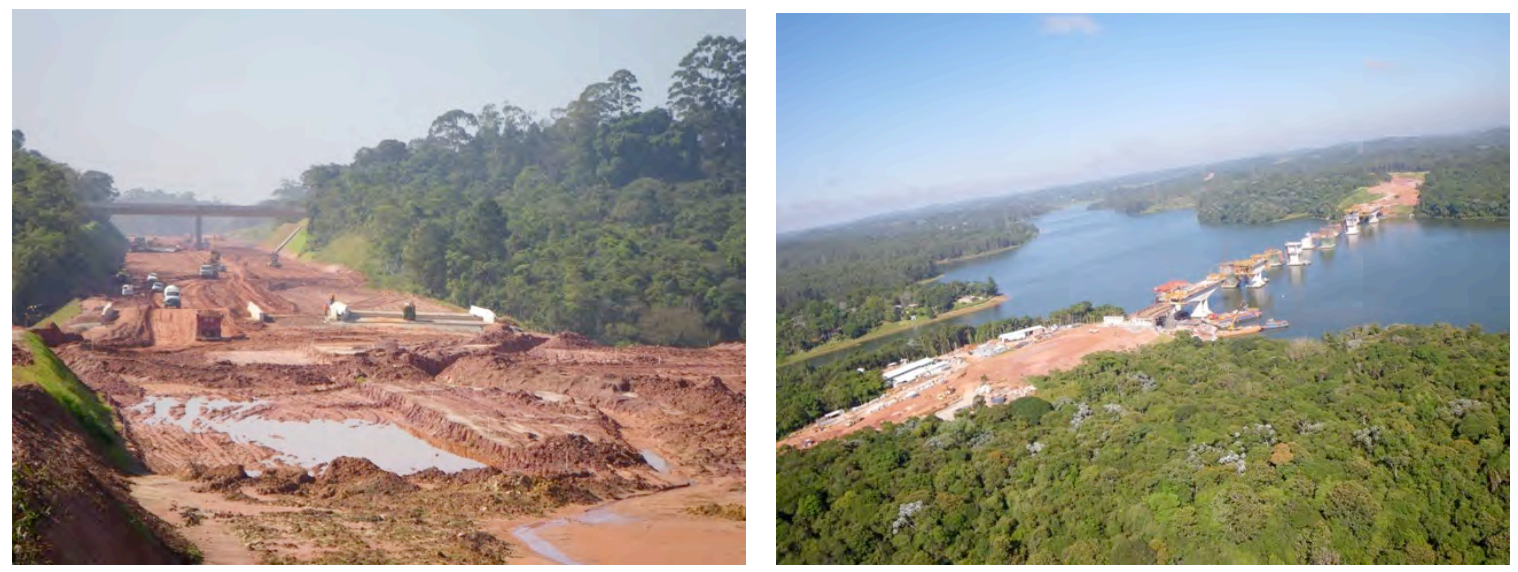

FIGURA 21 e 22: Canteiro de obras Rodoanel trecho sul REGISTRO FOTOGRÁFICO: Felipe Spina Avino (2008)

O recorte na paisagem afetou não apenas a biodiversidade abundante no local, mas em especial a população que teve sua dinâmica completamente alterada pelo Rodoanel. Os moradores que não foram removidos de suas casas, por meio de um processo pouco claro de desapropriação, tiveram suas vidas alteradas pela intensa poluição sonora audível em alguns pontos distantes da mata. Anteriormente a obra, o espaço sempre sofreu forte pressão por urbanização pelo fato de conter núcleos de moradias irregulares desassistidos de equipamentos urbanos e recortados por vias em péssimas condições de manutenção, além da pouca oferta de transporte público. A região é caracterizada pela precária infraestrutura urbana, especialmente, em seu sistema viário, tendo uma série de restrições disciplinadas pela legislação que protege os mananciais. A conexão com áreas centrais da cidade, que distam cerca de $30 \mathrm{~km}$ e abrigam a oferta de emprego, é completamente ineficiente tendo apenas uma via principal de acesso em um percurso com a duração de mais de duas horas via transporte público.

Contudo, o Rodoanel é inacessível em todo seu percurso sul e, por este motivo, a população local demanda fortemente a abertura deste através de uma alça de acesso pela via principal, avenida Sadamu Inoue, por conta da precariedade do sistema viário. Porém, é necessário destacar que se a abertura da via ocorrer haverá um catastrófico impacto ambiental e social porque atrairia um grande contingente de pessoas e, como consequência, acarretaria em um enorme impacto ocasionado pela intensa ocupação antrópica na região ambientalmente protegida. De fato, a alça não pode ter livre acesso, nem mesmo com a intensa pressão popular, porém, o melhor estratégia seria não 
construir uma via regional completamente descolada de um plano urbanístico e inutilizada pela população impactada socioambientalmente.

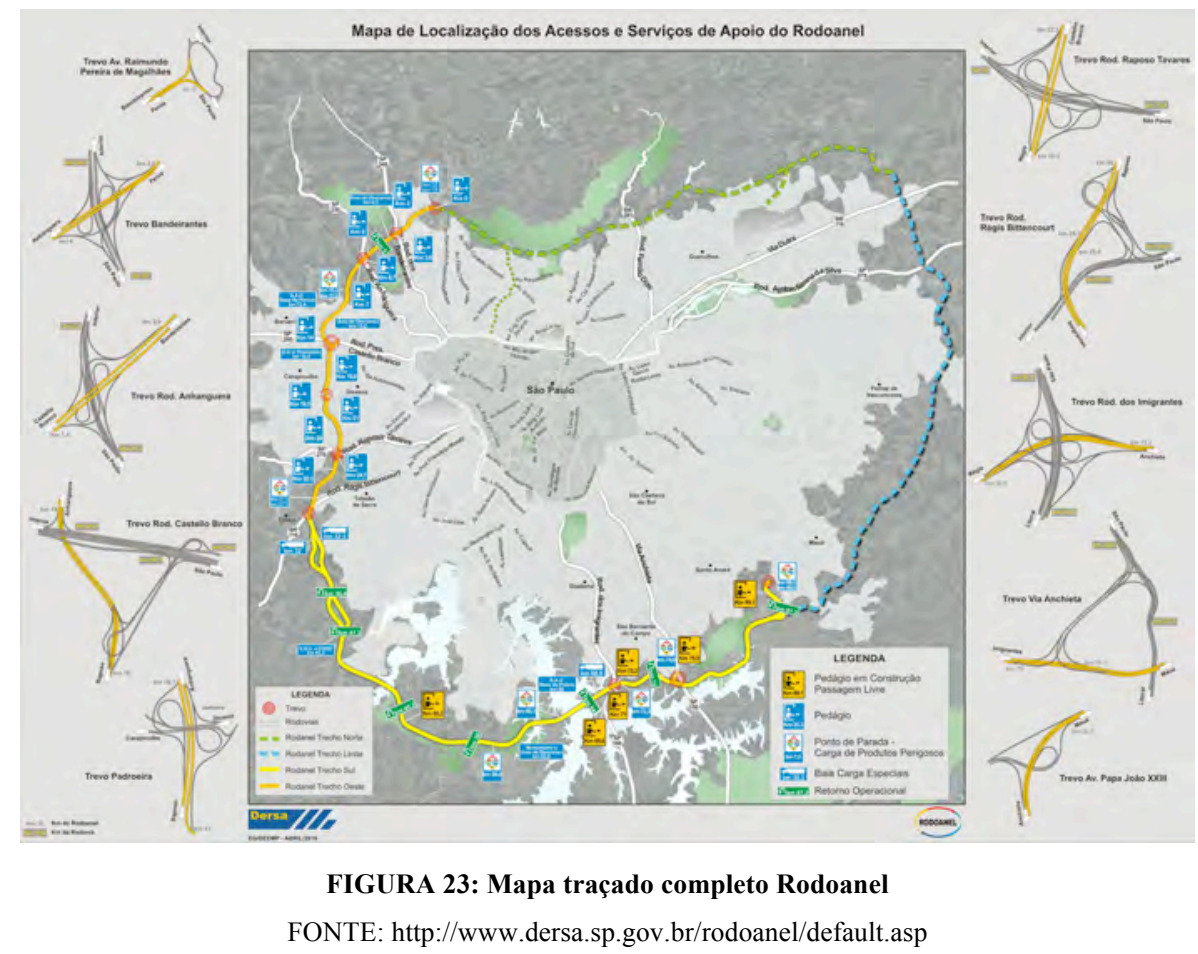

Em 2004, a população local chegou a se organizar para reivindicar além da compensação ambiental, a construção de um hospital, escolas técnicas e centros esportivos como uma espécie de compensação social, através de um documento cunhado "Carta de Parelheiros". Porém, não existe legislação para 'compensações sociais' e as solicitações da população não foram atendidas.

A fim de mitigar exclusivamente os impactos ambientais resultantes da construção do Rodoanel, foi gerado um processo de compensação ambiental licenciado pela Secretaria Estadual do Meio Ambiente, por se tratar de uma obra metropolitana. No âmbito municipal do Trecho Sul, a empresa DERSA foi responsável pelo plantio compensatório de 2.500.000 mudas de espécies nativas, assim como a implantação de quatro Unidades de Conservação de Proteção Ambiental, sendo os Parques Naturais Muncipais (PNMs) Bororé, Varginha, Itaim e Jaceguava, assim somando 1.500 .000 hectares de áreas ambientalmente protegidas. A Secretaria Municipal do Verde e do Meio Ambiente (SVMA), com base no Plano Diretor Municipal, foi a responsável pelo 
indicação das áreas e dos perímetros dos Parques Naturais, assim escolhendo as áreas mais preservadas sob a influência direta do empreendimento. Todavia, a empresa DERSA foi responsável por realizar o levantamento fundiário, desapropriar, cercar as áreas e implantar as sedes dos PNMs. A partir do cumprimento destas atribuições, os PNMs vão sendo entregues para a gestão da SVMA.

\subsubsection{UNIDADES DE CONSERVAÇÃO}

O cenário de preservação da biodiversidade na zona sul possibilitou a criação de Unidades de Conservação (UCs) como Parque Estadual Serra do Mar (PESM), em seu núcleo Curucutu, e as UCs municipais: Área de Proteção Ambiental (APA) CapivariMonos, Área de Proteção Ambiental (APA) Bororé-Colônia, também os cinco Parques Naturais Municipais (PNMs) Bororé, Varginha, Itaim, Jaceguava e Cratera de Colônia localizados abaixo: 


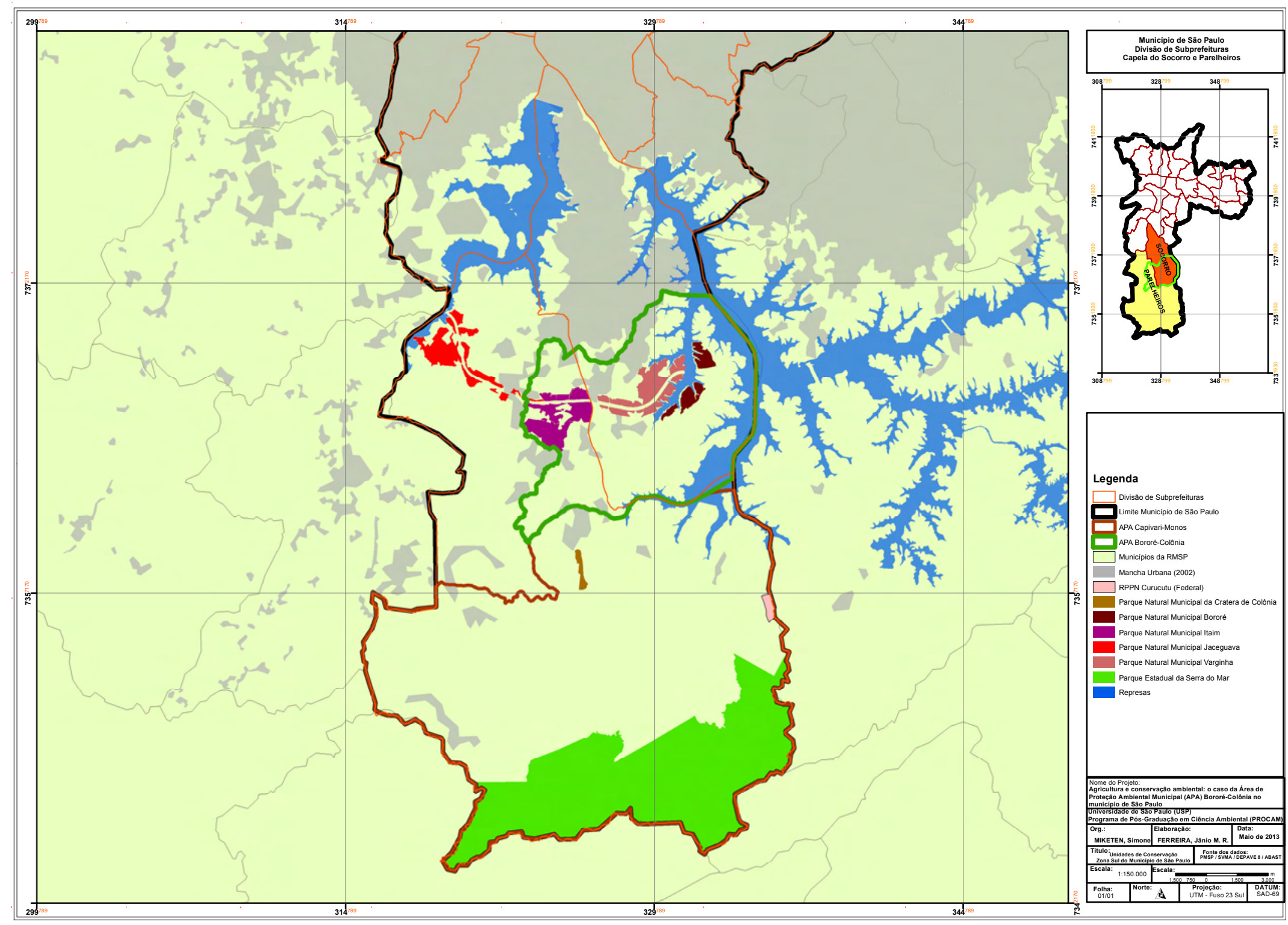




\subsubsection{PNMs - PARQUES NATURAIS MUNICIPAIS BORORÉ, VARGINHA, ITAIM, JACEGUAVA E CRATERA DE COLÔNIA}

De acordo com o SNUC (Lei Federal 9.985/2000), os Parques Naturais Municipais (PNMs) são Unidades de Conservação da categoria Proteção Integral, isto significa que suas áreas pertencem integralmente ao município, não sendo permitido a permanência de propriedades particulares em seu perímetro. Nestes espaços somente é admitido visitação de forma controlada para turismo estritamente ecológico, educação ambiental e pesquisas científicas. Qualquer atividade ocorrida dentro da área de um Parque Natural Municipal deve ser controlada e necessita de prévia autorização com o intuito de salvaguardar este patrimônio natural.

O primeiro Parque Natural Municipal a ser criado na zona sul foi o Cratera de Colônia no ano de 2007 pelo Decreto Municipal ( ${ }^{\circ}$ 48.423). É o único PNM localizado dentro do perímetro da APA Capivari-Monos e tem a singularidade de situar-se no interior de uma cratera formada pelo impacto de um corpo celeste, além de encontrar-se na região da Colônia Alemã, tendo uma grande relevância de preservação, histórica e cultural (SÃO PAULO, 2012, p. 224). Os Parques Naturais Municipais Bororé, Varginha, Itaim e Jaceguava foram criados em conjugado porque são provenientes da compensação ambiental do Rodoanel trecho sul. O conjunto de seus perímetros formam um importante desenho contíguo que possibilita desempenhar funções integradas no que diz respeito ao manejo, vigilância e até mesmo ao compartilhamento da gestão destas Unidades de Conservação. Sua localização estratégica na borda da mancha urbana consolidada possibilita, além da função de preservação da biodiversidade, formar um arco adjacente que serve de barreira para contenção da expansão urbana, amortecendo assim a ocupação de áreas preservadas situadas mais ao sul, além de salvaguardar os recursos naturais como água, qualidade do ar, permeabilidade da terra e fragmentos de floresta responsáveis pela manutenção da vida.

Entretanto, existe uma grande pressão da população local pela urbanização destes espaços, pois os fragmentos dos Parques Naturais estão circunscritos em áreas de crescente urbanização irregular desassistidas pelo poder público. Este cenário apresenta a grande fragilidade na própria composição destes Parques Naturais, onde o conflito central 
está na necessidade de restrições ambientais de áreas prioritárias para manutenção dos recursos naturais em divergência ao imperativo das pessoas por melhores condições de infraestrutura urbana e lazer em seus bairros. Por este motivo, os moradores situados no entorno são verdadeiros alicerces de proteção conjunta destas áreas verdes porque a vigilância de seus perímetros é insuficiente e o processo de fiscalização e aplicação de penalidades, referentes a crimes ambientais, fazem parte de um lento processo que muitas vezes nem mesmo se efetiva.

O apoio constante das comunidades que cercam os PNMs, em relação ao monitoramento da dinâmica cotidiana das áreas, deve ser fortalecido por meio do diálogo constante e de ações que beneficiem os atores locais como um todo, assim integrando a população local à gestão das UCs. Em contrapartida, a grande potencialidade socioambiental destas Unidades de Conservação está nas ferramentas de gestão, previstas pela legislação, que direcionadas de acordo com reivindicações locais, equalizadas e para além da preservação ambiental, podem otimizar o diálogo entre as comunidades e o poder público, transformando assim estes espaços em catalisadores de planejamentos integrados e participativos. Foram criadas estratégias de diálogo com a população local na tentativa de configurar estes territórios como unidades de planejamento e gestão, as quais assumem papel mobilizador frente à população local porque salvaguardam instrumentos como Conselhos Gestores próprios que visam integrar os atores locais na problematização da conservação ambiental.

Isto posto, o plano de manejo é o documento que efetiva a gestão e planejamento das UCs que, por meio de diagnósticos do meio físico, biótico e socioeconômico, aponta diretrizes para a consolidação de programas de uso público e projetos direcionados para o desenvolvimento local e educação ambiental, contando com ações de manejo e a própria infraestrutura dos Parques Naturais. Também cria instrumentos estratégicos como o zoneamento interno dos PNMs, assim como o zoneamento do entorno próximo (área de amortecimento) que estabelecem proposições acerca de usos externos e áreas com potencial de conservação e recuperação ambiental. A constituição de Conselhos Gestores consultivos abre espaço para mais um fórum de levantamento de exigências locais, podendo ser fortalecido pelo Conselho Gestor deliberativo e paritário existente na APA Bororé-Colônia que circunscreve três Parques Naturais: Itaim, Varginha e Bororé. 
Contudo, a porção norte de Parelheiros, onde localiza-se o Parque Natural Municipal Jaceguava, encontra-se fora do perímetro da APA Capivari-Monos e da APA Bororé-Colônia incidindo apenas os instrumentos ambientais da APRM-G. Cabe ressaltar que esta área tem um grandioso potencial ambiental, visto que abriga uma grande várzea do rio Embu-Guaçu, a várzea e nascentes do rio Caulim, além de extensas áreas de agricultura e empreendimentos que mantém a permeabilidade do solo como um clube de golfe e o Solo Sagrado, o qual pretende transformar sua área preservada em uma Reserva do Patrimônio Particular Natural (RPPN). Por conta deste potencial, devem ser realizados estudos a partir da Zona de Amortecimento do PNM Jaceguava afim de criar uma APA na localidade, formando uma importante barreira de proteção ambiental no eixo de expansão urbana sudoeste do município.

Abaixo seguem as compilações de diretrizes a respeito dos Parques Naturais Municipais pela normatização federal:

\section{LEI N ${ }^{0}$ 9.985, DE 18 DE JULHO DE 2000}

\section{SISTEMA NACIONAL DE UNIDADES DE CONSERVAÇÃO DA NATUREZA - SNUC}

Art. 11. O Parque Nacional tem como objetivo básico a preservação de ecossistemas naturais de grande relevância ecológica e beleza cênica, possibilitando a realização de pesquisas científicas e o desenvolvimento de atividades de educação e interpretação ambiental, de recreação em contato com a natureza e de turismo ecológico.

$\S 1$ o O Parque Nacional é de posse e domínio públicos, sendo que as áreas particulares incluídas em seus limites serão desapropriadas, de acordo com o que dispõe a lei.

§ 20 A visitação pública está sujeita às normas e restrições estabelecidas no Plano de Manejo da unidade, às normas estabelecidas pelo órgão responsável por sua administração, e àquelas previstas em regulamento.

$\S 4 \underline{\text { o }}$ As unidades dessa categoria, quando criadas pelo Estado ou Município, serão denominadas, respectivamente, Parque Estadual e Parque Natural Municipal.

FIGURA 22: SNUC

FONTE: http://www.planalto.gov.br/ccivil_03/leis/L9985.htm 


\subsubsection{APA CAPIVARI-MONOS}

A modalidade Área de Proteção Ambiental (APA) está na categoria de Unidade de Conservação de Uso Sustentável que diferencia-se de Parque Natural Municipal (PNM) pelo fato de abrigar, em seu território, áreas públicas preservadas conjugadas as terras privadas, visando o equilíbrio entre as atividades antrópicas e a proteção da biodiversidade. Com efeito, as áreas privadas são normatizadas por uma série de restrições para efeitos de preservação ambiental. Abaixo a definição de APA de acordo com a legislação federal:

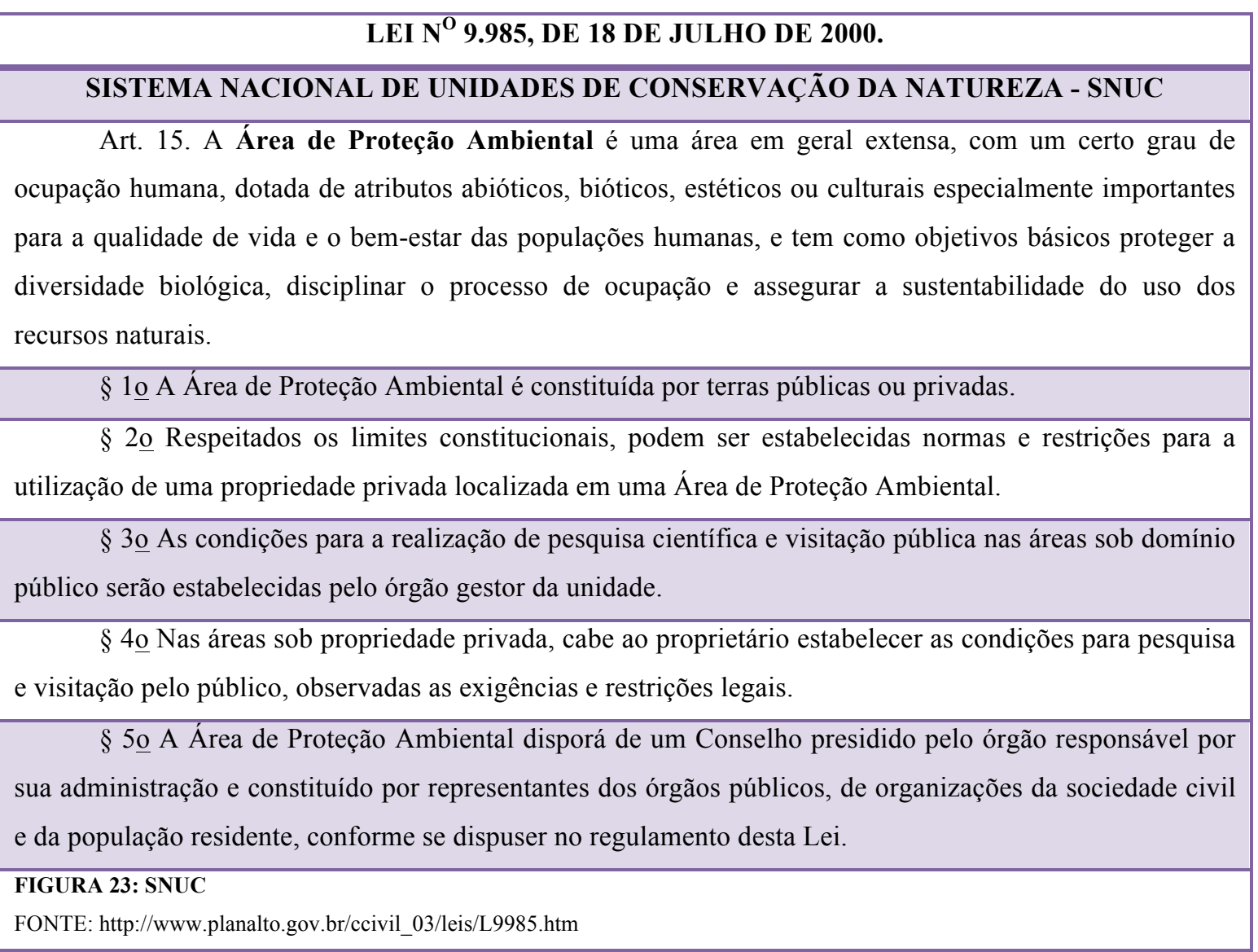

Na zona sul do Município existem duas Áreas de Proteção Ambiental, sendo a APA Capivari-Monos e a APA Bororé-Colônia (área de estudos), constituídas com o intuito de salvaguardar a mais extensa porção de biodiversidade de São Paulo, especialmente pela sobreposição que ambas as APAs têm com as Áreas de Proteção e 
Recuperação de Mananciais (APRMs) da bacia do Alto Tietê, além da bacia do rio Capivari.

Posicionada no extremo sul do Município, a APA Capivari-Monos (Lei Municipal $\left.n^{0} 13.136 / 2001\right)$ tem como limites:

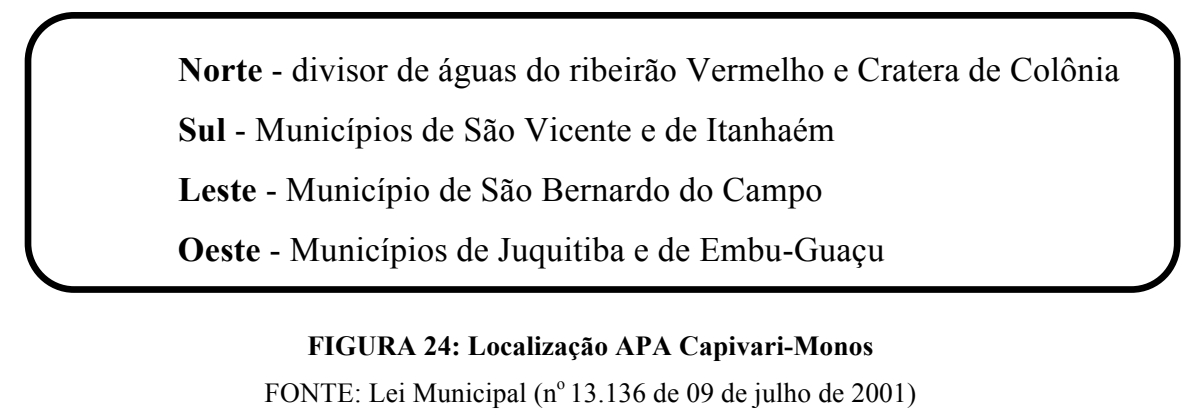

Esta grande extensão territorial inspira descrições poéticas, pois suas veredas recortam paisagens de abundante beleza cênica verdejadas por grandes fragmentos de floresta, além de formosas cachoeiras que transbordam do ainda vigoroso rio Capivari. A paisagem rural é inspirada na dinâmica de uma cidade pequena do interior do Estado, tendo a maior concentração de propriedades agrícolas do município. Por este motivo, tem a cadência do ritmo da cultura da terra, ora com esboços geométricos dos canteiros, ora pelo emaranhado da floresta secundária preservada. Este belo cenário reserva um expressivo potencial turístico ecológico e rural enredado em elementos preciosos históricos e culturais.

A grande proximidade física e social das APAs Capivari-Monos e Bororé-Colônia conecta uma série de ações e instrumentos de gestão e planejamento fortalecendo sua integração, destacando que, a criação da APA Capivari-Monos foi o impulso e o modelo de gestão para a concepção da APA Bororé-Colônia. Por este motivo, as ferramentas como o Plano de Manejo, o Conselho Gestor e o Zoneamento serão apresentados em conjunto, salvaguardando algumas especificidades de cada uma.

Os territórios que são configurados como Área de Proteção Ambiental, de acordo com o SNUC supracitado, apresentam em seu perímetro um certo número de ocupação antrópica que deve ser controlada para efeitos de preservação ambiental. Contudo, a necessidade de não apenas normatizar e punir, mas também incluir a sociedade civil 
torna-se uma das estratégias conjuntas de conservação ambiental e desenvolvimento social local, as quais são fomentadas pelo Plano de Gestão e seus programas indicados no Plano de Manejo, assim como na legislação.

O DEPAVE-8 (Divisão Técnica de Unidades de Conservação e Proteção da Biodiversidade e Herbário), da Secretaria do Verde e Meio Ambiente (SVMA), é responsável pela gestão das Unidades de Conservação municipais, tendo como atribuição a articulação estratégica local entre os diversos atores sociais e a coordenação de pesquisas e pareceres técnicos que fomentam as ações territoriais e projetos nas APAs.

Para isto, conta com a gestão integrada aos Conselhos Gestores respectivos a cada APA, os quais são atuantes de forma efetiva por seu caráter deliberativo e ainda pela presença de vários setores do poder público e da sociedade civil em caráter paritário. As reuniões ocorrem mensamente objetivando o levantamento de questões de diversos temas prioritárias da área para estabelecimento de um Plano de Gestão para a APA. As reinvindicações são agrupadas em diferentes Câmaras Técnicas com os seguintes temas: Monitoramento e Fiscalização, Uso e Ocupação do Solo, Gestão Socioambiental, Turismo Sustentável, Agricultura e Desenvolvimento Rural Sustentável, Infraestrutura e Saneamento (SÃO PAULO, 2011, p. 227). Cada Câmara Técnica tem autonomia para realizar reuniões extras com o intuito de dialogar a respeito de sua especificidade. $\mathrm{O}$ Conselho Gestor da APA Capivari-Monos foi fundado no ano de 2002, enquanto o Conselho Gestor da APA Bororé-Colônia iniciou seus trabalhos em 2005.

Contudo, outro instrumento de relevância para a gestão de uma APA é o Plano de Manejo que apenas foi consolidado na APA Capivari-Monos em 2010. A APA BororéColônia conta com um diagnóstico prévio que apresenta diretrizes para a realização do Plano de Manejo (que tem seu início em 2013). Estabelecido pelo DEPAVE-8, sob aprovação do Conselho Gestor, o documento foi construído a partir do diagnóstico local, da sistematização de informações e mapeamento, organização de oficinas participativas e criação de programas de gestão.

O plano de manejo de uma APA é uma ferramenta de gestão fundamental para a articulação local por definir as prioridades da área, assim como as atribuições dos diferentes atores envolvidos servindo de guia para a equalização entre a preservação ambiental e o desenvolvimento local. Os resultados deste material culminaram nos 
programas de gestão com os temas de maior relevância da APA Capivari-Monos: educação ambiental, agricultura, turismo, proteção, pesquisa científica, recuperação e gestão socioambiental. De acordo com o roteiro metodológico da Secretaria Estadual do Meio Ambiente, plano de manejo pode ser compreendido como:

o processo de articulação das ações propostas pelos diferentes agentes sociais que interagem em um determinado espaço, com vistas a garantir a adequação dos meios de exploração dos recursos naturais, econômicos e socioculturais às especificidades do meio ambiente, com base em princípios e diretrizes pré-definidos (SÃO PAULO, 2011, p. 228)

Outra ferramenta essencial para a gestão e planejamento é o Zoneamento Ecológico Econômico, regulamentado para a APA Capivari-Monos pela Lei Municipal $\left(n^{0} 13.706 / 04\right)$. Suas diretrizes foram fundamentadas nas legislações ambientais e urbanísticas incidentes em seus limites como as APRMs do Alto Tiête, a sobreposição com outras Unidades de Conservação e com terras indígenas, além de considerações relacionadas ao Plano Diretor Estratégico e ao Plano Diretor Regional da Subprefeitura de Parelheiros (SÃO PAULO, 2011, p. 27). Isto posto, o zoneamento implementado pela APA Capivari-Monos (Lei Municipal $n^{0} 13.706 / 2003$ ) disciplina o uso e ocupação da terra em caráter mais restritivo do que outras legislações previstas na área. De acordo com a Resolução CONAMA 10/88 e a Lei Orgânica Municipal em seu artigo 4 e inciso 4, toda Área de Proteção Ambiental deve conter um Zoneamento Ecológico Econômico (ZEE) que torna-se lei após a consolidação de seu Plano de Manejo.

O Zoneamento Ecológico Econômico é instrumento básico de planejamento e gestão que estabelece as normas de uso e ocupação do solo e de manejo dos recursos naturais em zonas específicas, defini- das a partir da análise de suas características ecológicas e socioeconômicas. Tem por objetivo identificar as unidades territoriais que, por suas características físicas, biológicas e socioeconômicas e pela dinâmica de uso e contrastes internos, devam ser objeto de disciplina especial, com vistas ao desenvolvimento de ações capazes de conduzir à preservação, conservação e manutenção dos ecossistemas, ao aproveitamento sustentável do potencial produtivo e à melhoria da qualidade de vida da população.

FIGURA 25: Conceito Zoneamento Ecológico Econômico

FONTE: (SÃO PAULO, 2011, p. 11) 
A proeminência da paisagem rural e das atividades agrícolas no território da APA Capivari-Monos trazem a valorização da agricultura por meio de ações e projetos articulados pela Câmara Técnica de Agricultura e Desenvolvimento Rural, a qual tem como pressuposto preceitos da agroecologia. Alguns temas são prioritários como o manejo de baixo impacto, a promoção do consumo consciente, o fortalecimento da agricultura familiar e da permanência do jovem na agricultura (SÃO PAULO, 2011, p. 237).

\section{OBJETIVOS ESTRATÉGICOS DO PROGRAMA DE GESTÃO EM AGRICULTURA APA CAPIVARI-MONOS}

1. Promover a soberania alimentar e o consumo consciente;

2. Promover extensão rural voltada para a agricultura sustentável;

3. Fomentar a organização dos agricultores;

4. Inserir os proprietários de áreas prestadoras de serviços ambientais nas estratégias públicas e privadas de valoração desses serviços;

5. Promover a diversificação das alternativas de geração de renda nas propriedades rurais;

6. Fortalecer a comercialização dos produtos agrícolas;

7. Fortalecer a Câmara Técnica de Agricultura e Desenvolvimento Rural Sustentável das APA

Capivari-Monos e Bororé-Colônia, garantindo a participação dos agricultores na gestão da agricultura na APA;

8. Institucionalizar a Casa de Agricultura Ecológica.

FIGURA 26: Objetivos estratégicos do Programa de Agricultura da APA Capivari-Monos FONTE: (SÃO PAULO, 2011, p. 243)

Abaixo seguem as localizações das APAs Capivari-Monos e Bororé-Colônia: 


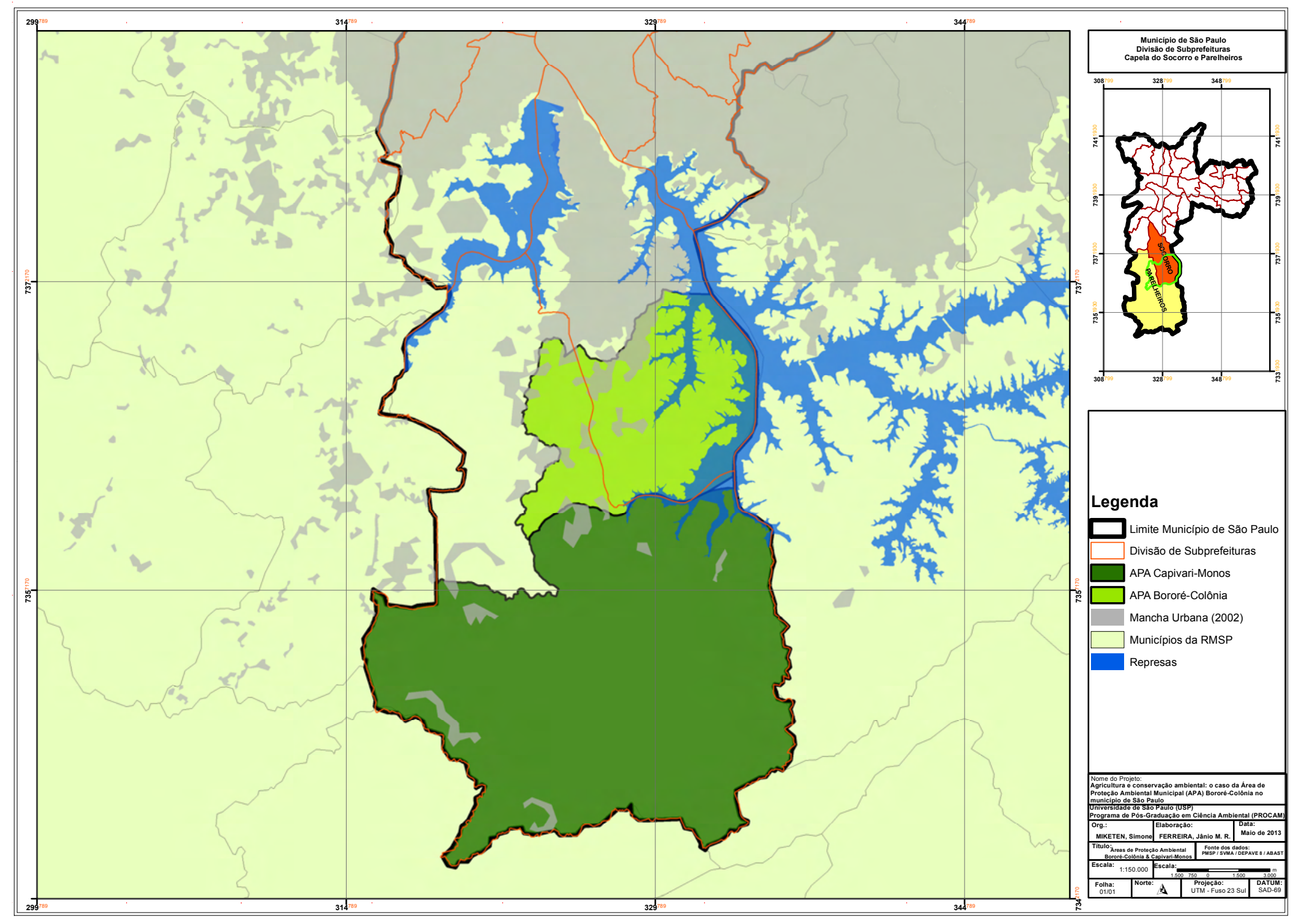




\subsubsection{APA BORORÉ-COLÔNIA - ÁREA DE ESTUDO}

A APA Bororé-Colônia foi criada pela Lei Municipal $\left(\mathrm{n}^{\mathrm{o}} 14.162 / 2006\right)$ visando a proteção das reservas da biodiversidade e dos recursos hídricos conjugada a moradias e equipamentos urbanos. Seu perímetro está localizado entre a mancha urbana consolidada e a APA Capivari-Monos, servindo como uma barreira que amortece a expansão urbana em direção a esta. De acordo com o Diagnóstico (SÃO PAULO, 2007) realizado para criação da APA Bororé-Colônia, os principais objetivos deste território são:

promoção do uso sustentável dos recursos naturais;

proteção da biodiversidade;

proteção dos recursos hídricos;

proteção da península do Bororé;

proteção do patrimônio histórico;

melhoria da qualidade de vida das populações.

A imagem de sua concepção ocorreu no bairro Ilha do Bororé em 1998, onde dialogava-se a respeito da criação de Áreas de Proteção Ambiental para salvaguardar a riqueza ambiental e cultural do extremo sul paulistano. Um convênio firmado entre a Associação de Moradores da Ilha do Bororé (AMIB) e a Secretaria Municipal do Verde e do Meio Ambiente (SVMA) manifestou a proposta da criação da APA na localidade. Em 2001 foi instituída a APA Capivari-Monos representando um modelo de gestão e planejamento participativo que subsidiaria a criação da APA Bororé-Colônia. O Seminário Billings, organizado em 2002 pelo Instituto Socioambiental junto aos técnicos da SVMA e Subprefeitura da Capela do Socorro, validou o território da região do Bororé como potencial para criação de uma APA. Em 2003 ocorreram Oficinas e Plenárias do Plano Regional de Capela do Socorro para no ano seguinte sair a proposta de traçado da APA Bororé-Colônia, o qual foi definido pela SVMA, a Subprefeitura de Capela do Socorro e a Subprefeitura de Parelheiros (SÃO PAULO, 2011).

O território da APA Bororé-Colônia dista cerca de $30 \mathrm{~km}$ do centro comercial da cidade, sendo que o aglomerado urbano consolidado adentra seu território ao norte, conformando o distrito do Grajaú que constitui uma das maiores áreas de vulnerabilidade social do município. Esta porção da APA apresenta uma paisagem bem distinta do 
restante do território, pois seus morros e vales são tomados por construções precárias que perduram por quilômetros entre estreitas alamedas.

Seu limite administrativo está inserido parcialmente no perímetro de duas Subprefeituras: Capela do Socorro e Parelheiros, as quais conformam a maior área do município, pois juntas representam 1/3 de São Paulo. Mesmo com esta extensa dimensão territorial, acomodam uma baixa densidade populacional e a maioria das áreas verdes preservadas do município. Contudo, por apresentarem espaços não ocupados pela população, tornam-se vulnerável à propagação da urbanização tendo os maiores índices de crescimento populacional do Município. É possível verificar que a mancha urbana consolidada espraia-se nos distritos da Subprefeitura de Capela do Socorro, e torna-se mais difusa na orientação sul formando pequenas centralidades. Outra característica importante é a inserção de ambas Subprefeituras em importantes APRMs da bacia hidrográfica do Alto Tietê, sendo a Subprefeitura de Parelheiros abrangendo as Subbacias hidrográficas da represa Guarapiranga, Billings e Capivari e a Subprefeitura de Capela do Socorro na Subbacia hidrográfica da represa Billings.

Abaixo segue a tabela com os números, referentes a área e a população das Subprefeituras, fornecidos pelo Portal da Secretaria de Coordenação de Subprefeituras do município de São Paulo (SMSP):

TABELA

\section{DADOS NUMÉRICOS SUBPREFEITURAS CAPELA DO SOCORRO E PARELHEIROS}

\begin{tabular}{|c|c|c|c|c|c|c|}
\hline subprefeitura & distrito & $\begin{array}{l}\text { área } \\
\mathbf{k m}^{2}\end{array}$ & $\begin{array}{l}\text { população } \\
\text { (1996) }\end{array}$ & $\begin{array}{l}\text { população } \\
\text { (2000) }\end{array}$ & $\begin{array}{l}\text { população } \\
\text { (2010) }\end{array}$ & $\mathrm{hab} / \mathrm{km}^{2}$ \\
\hline \multirow{4}{*}{ Capela do Socorro } & Cidade Dutra & 29,30 & 181,335 & 191,203 & 196.360 & 6.702 \\
\hline & Grajaú & 92 & 261,878 & 331,837 & 360.787 & 3.922 \\
\hline & Socorro & 12,90 & 40,983 & 39,139 & 37.783 & 2.929 \\
\hline & TOTAL & 134,20 & 484,196 & 562,179 & 594.930 & 4.433 \\
\hline \multirow{3}{*}{ Parelheiros } & Marsilac & 200 & 7,238 & 8,380 & 8.258 & 41.29 \\
\hline & Parelheiros & 153,50 & 78,188 & 102,274 & 131.183 & 855 \\
\hline & TOTAL & 353,50 & 181,335 & 191,203 & 196.360 & 6.702 \\
\hline
\end{tabular}

FIGURA 27: Densidade demográfica - Subprefeituras Capela do Socorro e Parelheiros 
O desígnio do território da APA Bororé-Colônia como área de estudo justifica-se por apresentar um relevante cenário do encontro rural-urbano, assim constituindo um espaço periurbano. O mapa abaixo delineia e situa a mancha urbana consolidada na RMSP, além de destacar as Subprefeituras de Capela de Socorro e Parelheiros que situam limites administrativos em que insere-se a área de estudo da presente pesquisa. 


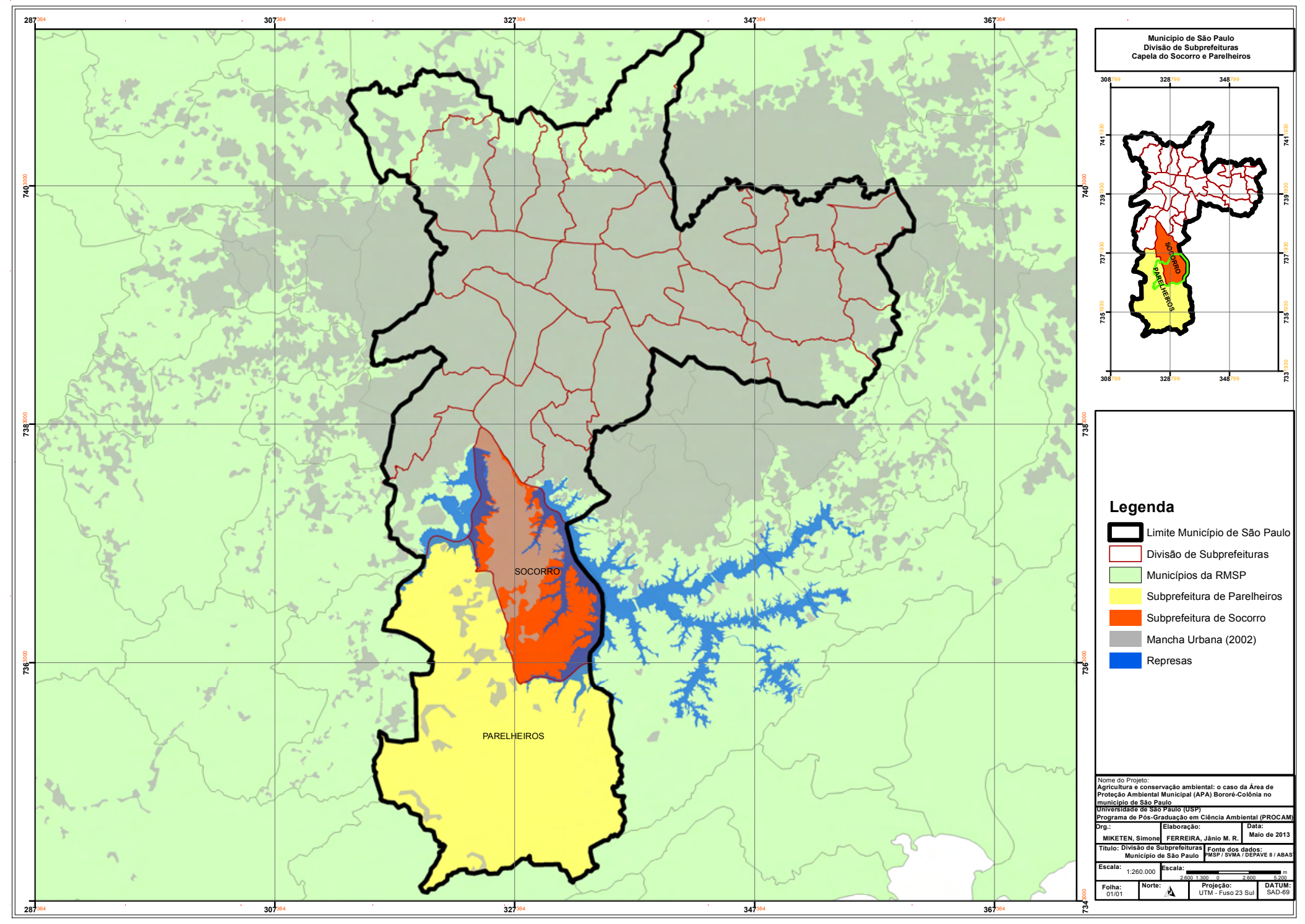


Ao norte também encontra-se grandes áreas de mineradoras em atividade, formando áreas de riscos de contaminação pelo excesso de metais pesados provenientes do subsolo. Contudo, a maior parte de sua porção territorial é constituída de áreas permeáveis constituindo assim uma paisagem verde colorada pela Floresta Ombrófila Densa e umidificada pelos altos índices pluviométricos desta configuração. A geomorfologia apresenta uma sequência de pequenos morros, os quais apresentam maior declividade na região central da APA, onde situa-se o Parque Natural Municipal Itaim que também reserva importantes nascentes do rio Caulim. A terra muitas vezes é encharcada pela proximidade dos lençóis freáticos, tendo predominância argilosa e de solo de aluvião.

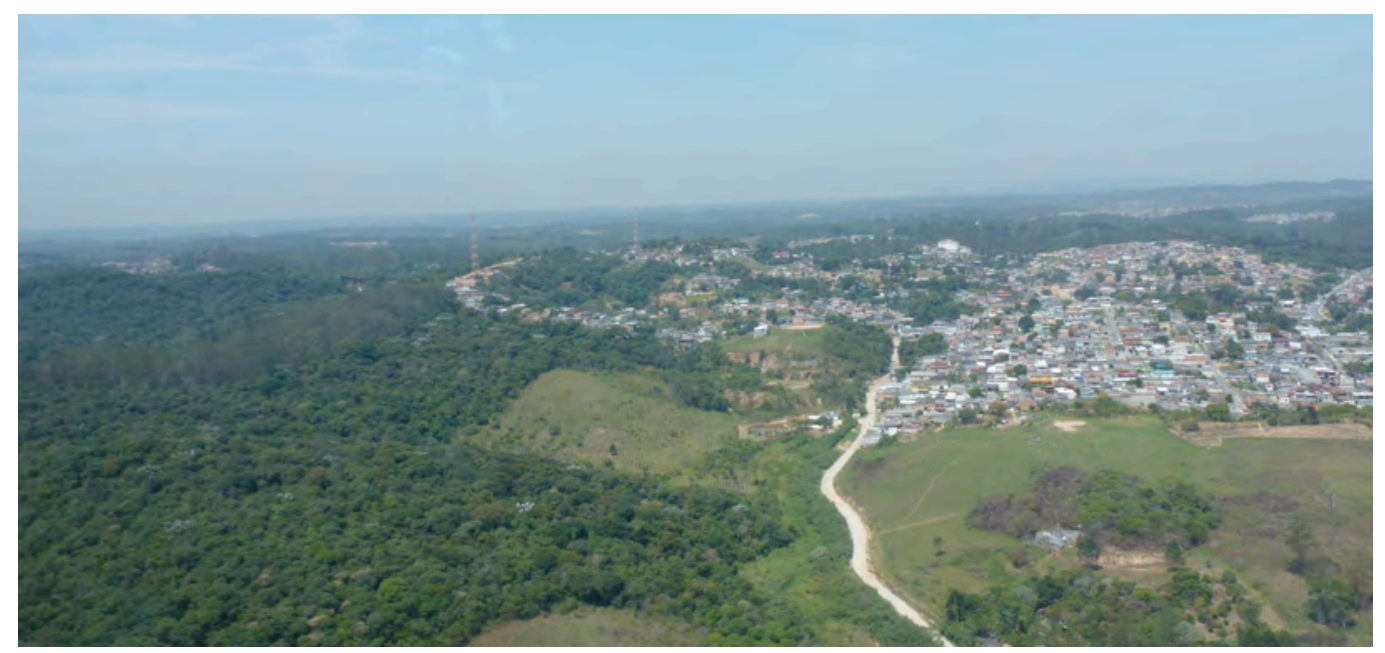

FIGURA 28: Limite PNM Itaim com a comunidade Jardim São Norberto REGISTRO FOTOGRÁFICO: Simone Miketen (fevereiro 2013)

O território é constituído de alguns usos que preservam a permeabilidade da terra como chácaras de lazer, as quais são usadas para eventos ou mesmo por famílias proprietárias que residem em localidades mais centrais da cidade. Algumas destas áreas foram desapropriadas para transformarem-se em áreas públicas constituindo os Parques Naturais Municipais, contando com três dentro do perímetro da APA: PNMs Bororé, Varginha e Itaim.

A predominância de japoneses cultivadores da terra é clara, mas também encontra-se descendentes germânicos e caboclos que estão há gerações na localidade. As variedades da produção agrícola mais comuns são de cultivos anuais como folhagens, 
legumes e raízes, além de frutíferas como banana, caqui e cambuci. Estes atributos podem ser encontrados principalmente nos bairros Ilha do Bororé (localizado a leste) e Chácara Santo Amaro (localizado no sul), onde se encontra a maior concentração de propriedades agrícolas. De acordo com o parecer técnico realizado pela SVMA acerca dos usos em potencial da APA Bororé-Colônia: "além do uso urbano, estas áreas apresentam uma vocação inequívoca para uso agrícola, sendo uma das últimas zonas caracteristicamente rurais do município de São Paulo" (SÃO PAULO, 2006). Este cenário fortaleceu iniciativas que buscam adequar o uso agrícola a um manejo de baixo impacto, ou seja, iniciativas que estimulam um processo de transição agroecológica que contam com diversas ações do poder público e de outros atores da sociedade civil.

Espraiado pelo território existem outras aglomerações urbanas irregulares que, cada vez mais, consolidam-se em bairros bastante precários e críticos como o caso dos Jardim São Norberto, Jardim Papai Noel e Jardim São Nicolau na porção noroeste da APA. Neste território apenas em 2010 foi permitido pela SABESP a chegada da rede de coleta de esgoto, porém sua efetivação não foi executada gerando contaminação em várias localidades do território.

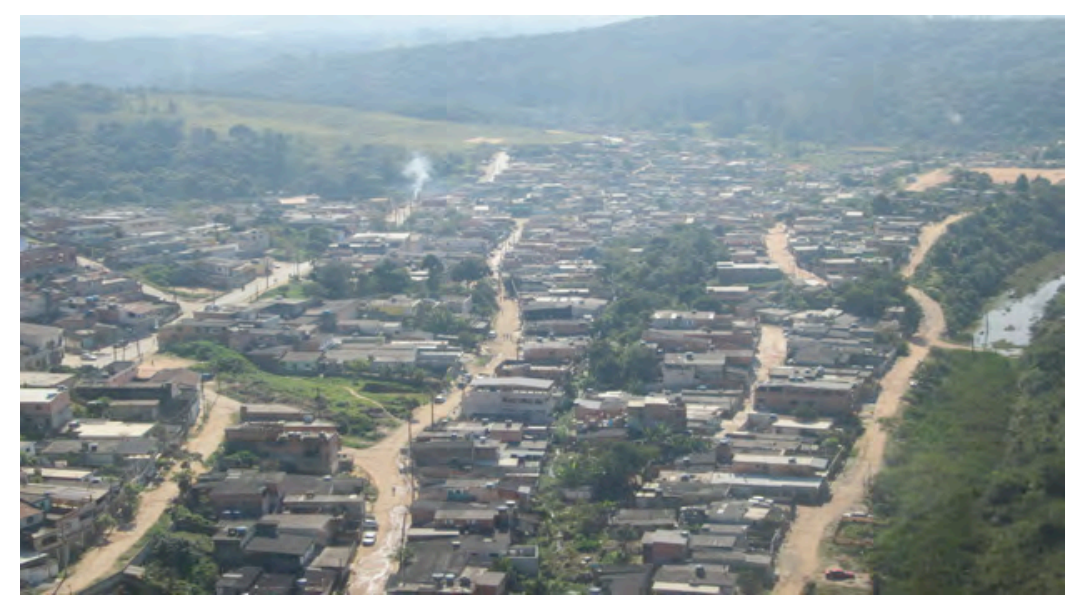

FIGURA 29: Comunidade Jardim São Norberto REGISTRO FOTOGRÁFICO: Diego Lustre Gonçalves (abril 2013)

A população estimada da APA Bororé-Colônia é de 40 mil habitantes, número este que está em crescimento esporádico devido ao lento processo de monitoramento e fiscalização dos órgãos públicos. Os equipamentos de infraestrutura em saúde e educação não atendem este contingente populacional, nem mesmo hospital existe neste território, 
apenas quatro Unidades Básicas de Saúde (UBS). A inexistência de atividades de lazer faz com que a população ocupe as áreas livres como o leito da represa Billings que, aos fins de semana, permanece lotada de banhistas, mesmo com a contaminação de suas águas. O sistema viário é de péssima qualidade, tendo uma malha precária com muitas alamedas estreitas ou estradas de chão que são conduzidas para poucas vias vicinais interligadas apenas em uma avenida principal, a qual integra toda a região ao centro comercial. Outro grande problema é que o transporte público não chega em boa parte dos bairros, obrigando os moradores a realizarem uma grande caminhada até o ponto de ônibus mais próximo.

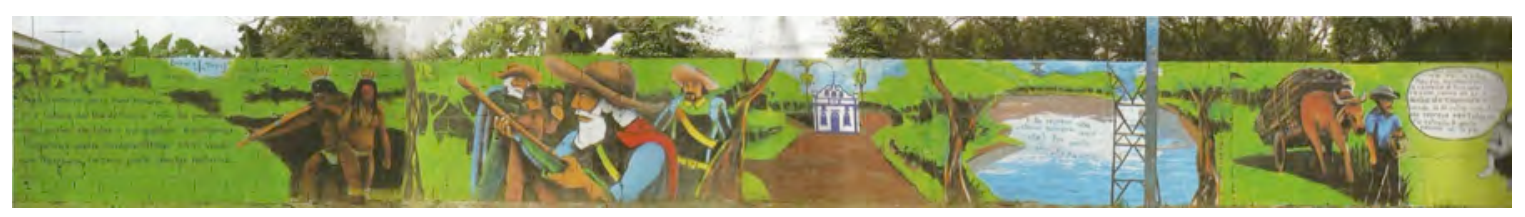

FIGURA 30: Muro grafitado pelo Coletivo Imargem na Ilha do Bororé

Uma das penínsulas da represa Billings à leste abriga um bairro com grande potencial turístico cunhado de Ilha do Bororé. O acesso é feito por dois pontos: o primeiro é a avenida Paulo Guilguer Reimberg, sendo uma estrada de chão que em seu percurso abriga diversas propriedades agrícolas, chácaras de lazer além de dois Parques Naturais Municipais (Varginha e Bororé). A segunda entrada do bairro pode ser feita por uma balsa que conecta o adensado distrito do Grajaú à paisagem rural da península do Bororé. Ao cruzar pela balsa as margens da represa Billings e adentrar na Ilha do Bororé, a percepção do choque entre a cidade e o campo salta aos olhos pela transfiguração brusca de paisagens. Esta localidade também resguarda o patrimônio histórico da Igreja de São Sebastião e em suas proximidades, encontra-se uma antiga Casa de Taipa datada de 1907. O contorno da represa por toda sua extensão também atrai pescadores que constituíram uma associação ARPO-BILLINGS dentro do bairro da Ilha do Bororé.

Abaixo seguem as coordenadas do território: 


\section{LOCALIZAÇÃO APA BORORÉ-COLÔNIA}

Art. 40 A linha de divisa da APA Bororé-Colônia é cartograficamente definida no mapa que constitui o Anexo Único desta lei, está descrita através do sistema de projeção UTM datum Córrego Alegre, cujas coordenadas estão expressas em metros na ordem de eixo $\mathrm{N}$ e E, respectivamente, e estão localizadas na banda de latitude K e zona de longitude 23 do sistema UTM, sendo assim descrita:

ponto 1 , de coordenadas 7.371 .540 e 332.477 , segue na direção sul, pelo limite municipal com São Bernardo do Campo, até o

ponto 2, de coordenadas 7.362.050 e 333.660, seguindo na direção oeste, pelo limite da Área de Proteção Ambiental Capivari-Monos, até o

ponto 3, de coordenadas 7.359 .592 e 323.678 , seguindo na direção noroeste, pelo divisor de águas das bacias hidrográficas das represas Billings e Guarapiranga, até o

ponto 4, de coordenadas 7.363.810 e 325.175. Deste ponto segue na direção norte, pelos logradouros rua Marquês de Lourical e rua Manoel Nóbrega Albuquerque, até o

ponto 5, de coordenadas 7.364.109 e 335.671, seguindo na direção noroeste, pela ju- sante da drenagem afluente do rio Parelheiros (ou Caulim), até o

ponto 6, de coordenadas 7.364.718 e 323.432, seguindo, na direção norte, pelo leito do rio Parelheiros (ou Caulim) até encontrar o

ponto 7, de coordenadas 7.366 .920 e 323.615, locali- zado na avenida Sadamu Inoue (antiga estrada de Parelheiros). Deste ponto segue na direção nordeste, pela avenida Sadamu Inoue (antiga estrada de Parelheiros), até o

ponto 8, de coordenadas 7.369.339 e 324.449, seguindo na direção leste, pela rua José Nicolau de Lima, até ponto 9, de coordenadas 7.369.448 e 324.852, seguindo na direção leste pela avenida Amaro Alves do Rosário, antiga estrada do Itaim, até o

ponto 10, de coordenadas 7.368.503 e 325.367, daí segue em linha reta, pela Linha de Transmissão, até o ponto 11 , de coordenadas 7.369 .072 e 326.118 , seguindo na direção sudeste, pelo divisor de águas das bacias hidrográficas das represas Billings e Guarapiranga, até o

ponto 12, de coordenadas 7.368.400 e 327.898, seguindo na direção nordeste, pela avenida Paulo Guilger Reimberg, antiga estrada da Varginha, até o

ponto 13 , de coorde- nadas 7.368 .569 e 327.899 , seguindo na direção nordeste, pelas estradas do Barro Branco e Shangrilá, até o ponto 14, de coordenadas 7.371 .706 e 330.104, seguindo na direção leste, pela jusante da drenagem tributária do reservatório Billings, até o

ponto 15 , de coordenadas 7.371 .572 e 331.000 , seguindo em linha reta, na direção leste, até encontrar ponto 1 , fechando o polígono. 


\subsection{MARCOS REGULATÓRIOS DA AGRICULTURA NA ÁREA DE ESTUDOS}

Os diversos usos antrópicos que compõem a área de estudos apresentam uma série de contradições quando refletidos nos marcos regulatórios de ordenamento territorial do Município. O principal instrumento, neste sentido, é o Plano Diretor Estratégico do Município (PDE), o qual tem como um dos objetivos regular a função social da cidade para "construir um outro modo de organizar a produção e o território, no âmbito da integração das políticas públicas e articulação das políticas públicas urbanas, compatível com os limites da sustentabilidade ambiental, social e econômica" (BRASIL, 2004, p. 40). O PDE é regulamentado pelo Estatuto da Cidade (Lei Federal n ${ }^{\circ} 10.257 / 2001$ ) que é um importante instrumento que normatiza os parâmetros e diretrizes do processo de urbanização nacional (BRASIL, 2004, p. 12). Este Estatuto foi idealizado como uma ferramenta fundamental de planejamento urbano que inaugura um modelo de gestão democrática, tendo como base o direito a moradia e a função social da propriedade. Isto resulta na renovação do pensamento acerca da cidade, sendo concretizado por meio de urbanização de favelas, das ferramentas de gestão participativas, dos zoneamentos especiais enfatizando, assim, a visibilidade dos problemas sociais (MARICATO, 2010) e ambientais.

Por outro lado, o Plano Diretor Estratégico (PDE) também objetiva o estabelecimento de parâmetros e diretrizes da zona rural do Município, desde que o espaço cumpra com sua função socioambiental de produção agrícola. De acordo com o Guia de elaboração de Planos Diretores (BRASIL, 2004), o estabelecimento do território rural deve ser organizado por uma leitura socioterritorial através do levantamento de características sociais, culturais e ambientais, assim como atividades agrícolas e não agrícolas (BRASIL, 2004, p. 59) que, condicionados aos objetivos do PDE, são parametrizados no macrozoneamento urbano e rural (BRASIL, 2004, p. 62). A existência de um Zoneamento Ecológico Econômico (ZEE) na área, assim como um cadastro georreferenciado dos imóveis rurais para figurar a estrutura fundiária (BRASIL, 2004, p. 60) são instrumentos fundamentais que amparam a determinação na constituição destas áreas. 
De acordo com os parâmetros supracitados, é bastante claro que os instrumentos que normatizam as diretrizes de uso e ocupação do solo, assim como a articulação de políticas públicas do território municipal, estão contidos no Plano Diretor Municipal Estratégico (PDE) e são pautados pela dicotomia urbano e rural. Contudo, os territórios periurbanos, que mesclam e sobrepõem usos rurais e urbanos, mostram-se como grandes desafios para o discernimento e a efetivação de instrumentos que normatizem certas especificidades em relação ao seu zoneamento, assim necessitando de soluções inovadoras:

De um modo geral, as partes da zona rural contíguas à zona urbana apresentam-se em processos de conversão de uso da terra e de reestruturação fundiária. Nessas áreas há uma sobreposição entre territórios urbanos e rurais característica dessa transição entre formas diferentes de apropriação do solo. Dependendo do ritmo e padrão da expansão urbana, esses processos podem ser mais ou menos acelerados. Dependendo da consolidação do sistema municipal de planejamento e gestão territorial, esses processos podem ser mais ou menos regulados. (...) Essas áreas periurbanas, urbanas ou do entorno urbano imediato, são bastante indefinidas. As ocupações apresentam baixos graus de consolidação. Muitas vezes essas áreas são encaradas como problemas, mas, se observarmos bem, verificaremos a existência de várias potencialidades que podem ser convertidas em soluções. Por exemplo, essas áreas podem ser aproveitadas para introduzir novos padrões de produção agrícola intensiva, com alto valor agregado e articulado com a política municipal de abastecimento, capazes de constituir alternativas de geração de emprego e renda para os moradores dos bairros periféricos (BRASIL, 2004, p. 64).

No caso da capital paulista, anteriormente à consolidação do PDE em 2002, existia o zoneamento que caracterizava o território rural do município: a Zona Especial de Uso Rural do Município (Z8-100), a qual foi foi regulamentada pela Lei Municipal ( $\mathrm{n}^{\circ}$ 8.328/1975). A Z8-100 era subdividida em cinco tipologias que aumentavam seu caráter restritivo de acordo com a distância das áreas urbanizadas, sendo: 


\section{TIPOS DE ZONA ESPECIAL DE USO RURAL - Z8-100 \\ Z8-100/1}

Servindo como transição entre o urbano e o rural, com permissão de atividades isoladas em grandes terrenos, conjuntos habitacionais e núcleos industriais para pequenas e médias industriais.

\section{Z8-100/2 a Z8-100/4}

Na medida em que a região vai se tornando menos ocupada, definiu-se uma transição entre o urbano e o rural, representada por esses três tipos de zona, numa ênfase crescente à preservação da vegetação e ao lazer, através da permissão de instalação de clubes e residências de recreio em terrenos cujas áreas mínimas variam de 1.000 a $10.000 \mathrm{~m}^{2}$, conforme a zona de uso.

\section{Z8-100/5}

No último tipo de zona rural só se permitem os usos de lazer e residencial de recreio em terrenos cuja área mínima varia de 20.000 a $50.000 \mathrm{~m}^{2}$, conforme o uso a ser instalado.

\section{FIGURA 32: Z8-100}

FONTE: http://www.prodam.sp.gov.br/sempla/zone.htm

Porém, a nova regulamentação estabelecida pelo PDE em 2002 (Lei Municipal n ${ }^{0}$ 13.430) suprimiu o território rural do município, assim estabelecendo a porção do extremo sul como uma Macrozona de Proteção Ambiental com diversas zonas especiais, assim reservando para o uso agrícola as Zonas Especiais de Produção Agrícola e Extração Mineral (ZEPAG):

\section{PLANO DIRETOR ESTRATÉGICO}

LEI MUNICIPAL No 13.430, DE 13 DE SETEMBRO DE 2002

\section{DA ZONA ESPECIAL DE PRODUÇÃO AGRÍCOLA E DE EXTRAÇÃO MINERAL - ZEPAG}

\section{SUBSEÇÃO III}

Art. 169 - As Zonas Especiais de Produção Agrícola e de Extração Mineral - ZEPAGs são porções do território municipal, em que haja interesse público expresso por meio desta lei, dos planos regionais ou de lei especifica, em manter e promover atividades agrícolas e de extração mineral.

$\S 2^{\circ}$ - Os imóveis localizados nas Zonas Especiais de Produção Agrícola e de Extração Mineral - ZEPAG, não serão enquadrados como urbanos enquanto forem utilizados para fins de produção agrícola e de extração mineral, desde que comprovados por órgão competente.

\section{FIGURA 33: Zona Espacial de Produção Agrícola e Extração Mineral (ZEPAG) \\ FONTE: Lei Municipal (n 13.430 de 13 de setembro de 2002)}

A zona rural e toda sua complexidade foi convertida apenas em atividades econômicas de exploração da terra, além de parcelada e pulverizada em pequenos 
recortes territoriais sem um mapeamento georreferenciado condizente das propriedades agrícolas. Como consequência, o território rural ficou resumido à sua atividade econômica e o produtor rural tornou-se produtor agrícola no perímetro urbano e periurbano. Esta mudança vem gerando uma série de dificuldades ao produtor, pois o enquadramento nas legislações que normatizam a agricultura, como a regulamentação da agricultura familiar (Lei Federal $n^{0} 11.326 / 2006$ ), provêm benefícios para a atividade agrícola em território rural. No caso do Município de São Paulo, a supressão do território rural gerou uma série de dificuldades para as propriedades agrícolas como: (1) dificuldade de acesso aos benefícios como assistência técnica e extensão rural, (2) falta de concessão de crédito rural como o Pronaf (Programa Nacional de Agricultura Familiar), (3) restrições para a participação em programas de compras públicas junto a órgãos estaduais e federais entre outros. De acordo com o relato da Diretora da Supervisão Técnica de Abastecimento (ABAST):

A CATI (Centro Estadual de Assistência Técnica Integral) tem atendido eventualmente, uma vez por semana, com assistência técnica e é a unidade que pode dar ao agricultor a declaração de aptidão ao PRONAF (DAP). A DAP é um documento que diz que ele é um agricultor familiar e se ele quiser acessar crédito no PRONAF ele pode, inclusive entregar para a merenda federal. Mas para ter DAP tem que estar no meio rural. (...) Fui estudar o Plano Diretor e ele faz um zoneamento e cria zonas especiais de produção agrícola e extração mineral (ZEPAG). (...) Cada vez que o agricultor quer DAP vai lá marca o ponto com GPS e nas coordenadas tais está em meio rural segundo o Plano Diretor. (...) Eles pagam ITR, mais um motivo para dizer é rural. IPTU acaba com o cara. Os caras precisam ser reconhecidos como zona rural. Andar lá é rural (trecho entrevista Nadiella Monteiro, novembro 2011).

As ZEPAGs, mesmo não sendo áreas rurais stricto senso, resguardam os usos especiais da produção agrícola e, por este motivo, é possível encontrar algumas lacunas na legislação para favorecer às propriedades agrícolas. Porém, a regulamentação e os benefícios de tão importante atividade econômica no município não podem ser fortalecidos pela exceção. Para este efeito, a revisão do PDE, que ocorre há cada dez anos, deve ser pautada na promoção da agricultura visando estudos de viabilidade da reconstituição do território rural municipal ou mesmo que potencializem a agricultura urbana e periurbana. Entretanto, existem uma série de controvérsias que precisam ser 
esclarecidas a fim de aprofundar este debate, sendo: (1) a confusão entre a localização dos imóveis e as atividades exercidas nestes; (2) o parcelamento do solo e a contensão da expansão urbana; (3) a questão fundamental da regularização fundiária; (4) a arrecadação dos Imposto Territorial Rural (ITR) e Imposto Predial e Territorial Urbano (IPTU); (5) maneiras de fortalecer o território rural na esfera municipal; (6) o perfil do agricultor localizado no espaço periurbano; (7) a multifuncionalidade da agricultura e (8) o perfil pluriativo do agricultor localizado no espaço periurbano.

O primeiro item já foi apontado nos capítulos anteriores, contudo, a grande confusão acerca da relação entre a localização dos imóveis e as atividades desenvolvidas nestes sucinta uma questão: o imóvel que está localizado na zona urbana e desempenha atividades agrícolas é estabelecido como rural ou urbano? O Estatuto da Terra ${ }^{19}$ (Lei Federal $\left.\mathrm{n}^{\circ} 4.504 / 1964\right)$ determina que, independente de sua localização, o imóvel será definido como urbano ou rural de acordo com a atividade que desempenha, assim dissociando claramente a localização da atividade. Contudo, existem outras condicionantes que definem o imóvel rural ${ }^{20}$, como exemplo, o lote mínimo permitido no território rural paulista $\left(20.000 \mathrm{~m}^{2}\right)$. Este serviria de barreira à urbanização visto que apresentam um tamanho superior ao lote urbano, além de critérios mais restritivos de ocupação.

Outra grande questão existente no extremo sul do município paulistano é a falta de regularização fundiária, pois diversos agricultores não possuem a titularidade das propriedades em que estão localizados, assim gerando mais uma grande desconformidade com a legislação agrícola que exige a documentação para os beneficiários de programas públicos. A reconstituição do território rural no município contaria com a parceria do INCRA (Instituto Nacional de Colonização e Reforma Agrária), órgão federal responsável pela regularização fundiária das áreas rurais. Como consequência, o desacerto existente na cobranças de Imposto Territorial Rural (ITR) e Imposto Predial e

\footnotetext{
${ }^{19}$ Legislação Federal que normatiza os imóveis rurais para fim de Reforma Agrária e promoção da Política Agrícola.

${ }^{20}$ De acordo com o artigo 4 do Estatuto da Terra o imóvel rural é definido como "prédio rústico, de área contínua qualquer que seja a sua localização que se destine à exploração extrativa agrícola, pecuária ou agroindustrial, quer através de planos públicos de valorização, quer através de iniciativa privada".
} 
Territorial Urbano (IPTU) das Subprefeituras de Parelheiros e Capela do Socorro, advindo de desconformidades na ordenação territorial, poderia ser solucionado. Outra particularidade do rural paulistano seria a necessidade de serem previstos recortes em seus interstícios das áreas urbanas consolidadas, as quais seriam regularizadas para pagamento de IPTU e provimento de infraestrutura urbana. As áreas do território rural seriam tributadas com o ITR que é arrecadado pela União, entretanto, o artigo 48 do Estatuto da Terra prevê um convênio que pode ser firmado entre a União e o Município para que este também receba a receita do ITR.

Neste sentido, o estabelecimento do território rural poderia ser concebido pela esfera municipal, pois a tributação e as atribuições das áreas rurais normalmente ficam sob competência do Estado e da União, o que vem distanciando o poder municipal destes espaços. O território rural no município de São Paulo pode ser potencializado a partir da esfera municipal, inclusive, porque possui três Casas de Agricultura Ecológica Municipais responsáveis pela a assistência técnica e a extensão rural das propriedades que participam de programas públicos. Isto pode abrir precedentes à ampliação da atividade agrícola para sua multifuncionalidade, pois além de produzir alimentos para a cidade pode também ser uma importante ferramenta de conservação ambiental. Porém, a facilidade de acesso da família rural à oferta de empregos urbanos, pode dificultar o enquadramento do perfil do agricultor, o qual pode ter sua renda advinda de fontes mais rentáveis que a atividade agrícola.

A hipótese de reconstituição da zona rural não deve ser descartada, visto que existem exemplos concretos como o caso do município de Nova-Iguaçu apontado pelo Prof. Dr. Nabil Bonduki ${ }^{21}$ :

No Plano Diretor de Nova-Iguaçu foi recriada zona rural. (...) Lá na discussão apareceu exatamente a questão de que os agricultores em função da agricultura urbana não conseguiam receber financiamento. $\mathrm{E}$ foi aí que isso me alertou que uma questão semelhante deveria estar acontecendo em São Paulo. (...) a ZEPAG não é zona rural stricto senso, mas é como se fosse zona rural embora ela não seja. Para efeito de financiamento a ZEPAG deveria ser considerada uma zona rural porque o PDE define

\footnotetext{
${ }^{21}$ O Prof. Dr. Nabil Bonduki compôs a equipe responsável pela concepção do PDE do município de São Paulo em 2002 e atualmente atua na revisão do mesmo em 2013.
} 
claramente que é uma zona destinada ao desenvolvimento de atividades agrícolas. Não teria sentido ela não ser isso. Não haveria razão para não ser considerada zona rural para esse efeito. (...) Assunto que precisa ser trabalhado com mais profundidade na revisão do PDE (trecho entrevista Nabil Bonduki, agosto 2012).

Por este motivo, é necessário fazer um levantamento detalhado das unidades de produção agrícola no extremo sul objetivando a caracterização das áreas produtivas e ponderando seu potencial rural e/ou periurbano, além de fomentar a proteção de áreas ambientalmente preservadas. Nesse sentido, o manejo agroecológico em mananciais deve ser apontado na revisão da legislação.

As ZEPAGs precisam ser dissociadas da extração mineral, pois as atividades agrícolas cultivadas por técnicas agroecológicas não têm a mínima associação coerente com as atividades das mineradoras. Estes dois tipos de atividades econômicas não são compatíveis entre si, pois as mineradoras exploram o solo e podem contaminar a terra a ponto de necessitar uma regulamentação especial para minimização de impactos. Em contraponto, o cultivo agrícola livre de agrotóxicos e adubos minerais, além de não causar grandes impactos, protege os recursos naturais e a qualidade da terra. Entretanto, existem as Zonas de Proteção e Desenvolvimento Sustentável (ZPDS) que também permitem atividades agrícolas e são mais coerentes do que as ZEPAGs pelo fato de permitir usos diversos compatíveis com a preservação ambiental, independente de especificidades como agricultura e extração mineral.

Outro ponto que necessita de revisão no estabelecimento das ZEPAGs é a sobreposição das mesmas com o mapeamento georreferenciado das propriedades agrícolas, visto que, como ilustra o mapa abaixo, a maioria das unidades de produção agrícola estão situadas fora das ZEPAGs.

Cabe ressaltar que, no território da APA Capivari-Monos a Lei de Zoneamento incidente é a própria legislação da Unidade de Conservação (Lei Municipal $\mathrm{n}^{0}$ 13.706/2004), visto que seu Zoneamento Ecológico Econômico (ZEE) já foi decretado. De acordo com o Artigo 67 do Plano Regional Estratégico da Subprefeitura de Capela do Socorro, as ZEPAGs "poderão sofrer ajustes em seus perímetros e nos usos permitidos, com vistas à sua adequação ao Zoneamento Ecológico Econômico, em conformidade com a legislação específica sobre Unidades de Conservação" (Lei Municipal $\mathrm{n}^{\circ}$ 
13.885/2004). O Artigo 83 do Plano Regional Estratégico da Subprefeitura de Parelheiros "estabelece o Zoneamento Geoambiental da APA Capivari-Monos" (Lei Municipal $n^{0}$ 13.885/2004). O ZEE da APA Capivari-Monos denomina as zonas de potencial para agricultura como Zona de Uso Agrícola (ZUA) apontadas abaixo. O território da APA Bororé-Colônia ainda não estabeleceu seu Zoneamento Econômico Ecológico e, pelo fato de estar iniciando seu Plano de Manejo em 2013, pode beneficiar-se do georreferenciamento das propriedades agrícolas, que vem sendo realizado desde 2010, para estabelecer com maior precisão seu próprio zoneamento agrícola. Abaixo segue o mapa com a sobreposição cartográfica dos pontos onde se localizam as propriedades agrícolas e as áreas que foram estabelecidas como ZEPAGs na zona sul do município. 


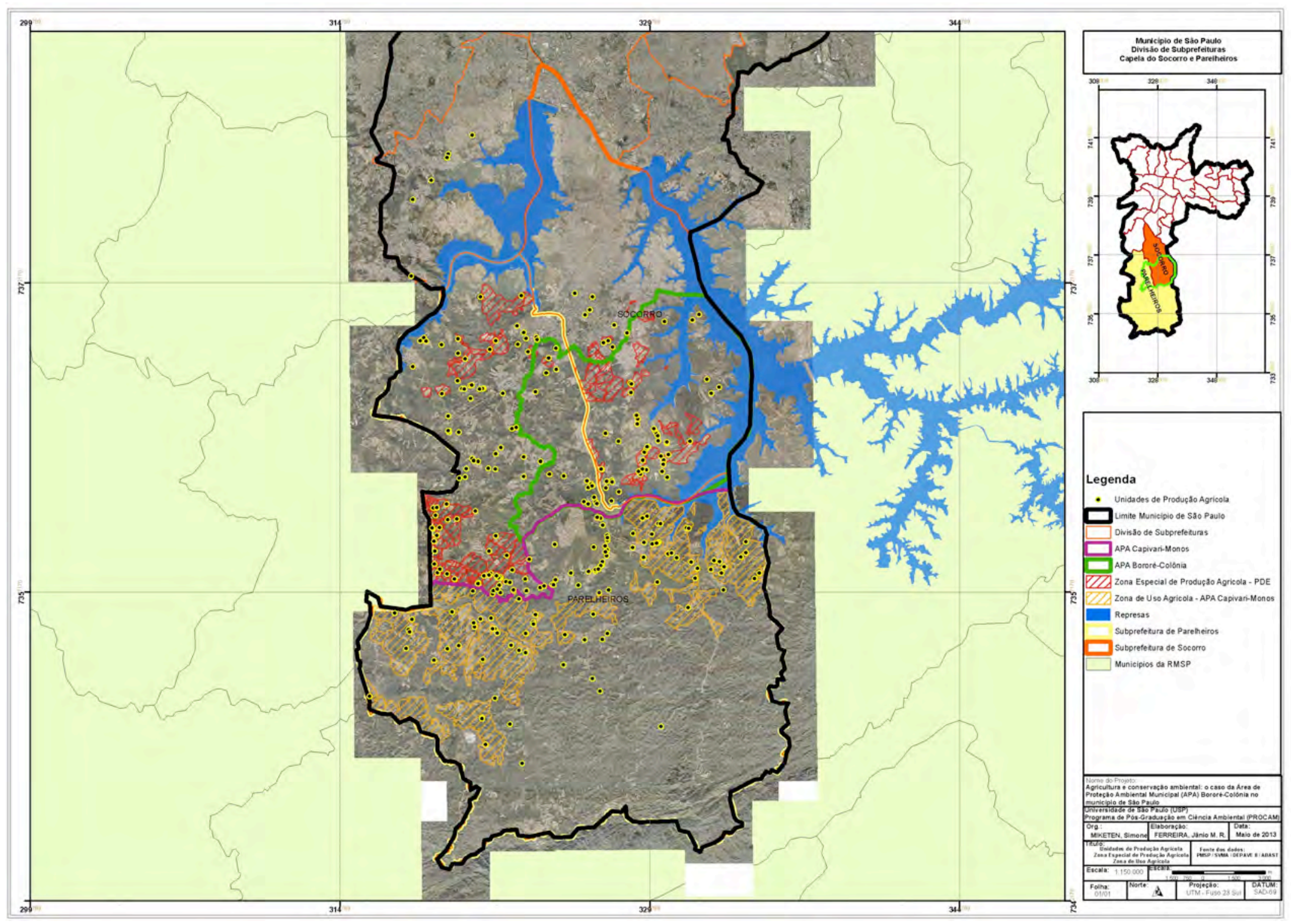




\subsection{PLANOS DIRETORES REGIONAIS}

As normas que parametrizam a atividade agrícola na zona sul apresentam uma série de ferramentas e estratégias, que bem administradas, podem fortalecer a agricultura no âmbito municipal. Contudo, a efetivação destes instrumentos deve ser refinada a partir da realidade local, buscando ponderar as vozes dos produtores locais com a necessidade de um manejo agroecológico afim de auxiliar a conservação ambiental da área. Os Planos Diretores Regionais (PDRs) representam um olhar institucional mais próximo da realidade local, trazendo informações e elementos elaborados por técnicos que vivem e convivem naquele recorte territorial. Por este motivo, torna-se relevante trazer o questionamento sobre rural, urbano e periurbano focalizado na análise nas Subprefeituras de Capela do Socorro e Subprefeitura de Parelheiros que incidem na área de estudos.

O Plano Diretor Estratégico de escala municipal não apresenta referências às áreas rurais, diferentemente dos PDRs supracitados. Estes destacam, em seus respectivos textos, a importância do desenvolvimento rural de seus territórios e da aplicação de ferramentas que impeçam a urbanização destas áreas, mostrando que o território necessita de estratégias de proteção ambiental, assim como alternativas econômicas que estejam alinhadas com a conservação ambiental de tão importante área de mananciais. Os PDRs especificam que os imóveis localizados nas ZEPAGs compõem a zona rural do município e por isso, deve-se impedir a urbanização e realizar a manutenção da infraestrutura neste sentido. Deve-se destacar que infraestrutura rural é diferente de infraestrutura precária e pode ser definida como o conjunto de elementos que estruturam e integram de forma estratégica aglomerados antrópicos ao ambiente natural, tais como: estradas rurais com pavimento permeável, eletrificação rural, uso de energias sustentáveis, reflorestamento, regularização de corpos hídricos, abertura de poços artesianos, sanemaneto através de construção de fossas sépticas, reutilização de água da chuva, além de uso de tecnologias de bioconstrução.

Contudo, é importante ressaltar que o território de Parelheiros tem uma configuração diferente do território de Capela do Socorro por conta da maior incidência de áreas preservadas e de propriedades agrícolas. O primeiro capítulo do PDR de Parelheiros aponta que seu território compreende uma "Macroárea de Uso Sustentável 
caracterizada por processo de ocupação de uso rural misto sustentável" (Lei Municipal n ${ }^{0}$ 13.885/2004). Com efeito, o perímetro que compreende a Subprefeitura de Parelheiros, especialmente na área da APA Capivari-Monos, apresenta caraterísticas de paisagem tipicamente rural, um grande número de propriedades agrícolas conjugados à paisagem natural, além de distar mais de $40 \mathrm{~km}$ do aglomerado urbano. Isto mostra seu potencial de possível adequação para a reconstituição de uma zona rural normatizada a partir de usos sustentáveis. Esta potencialidade aparece nos depoimentos de gestores públicos e ONGs locais:

$\mathrm{Na}$ zona sul os agricultores são periurbanos, ou seja, agricultores com uma realidade rural dentro de uma cidade urbana como São Paulo. Na zona leste e norte já são agricultores urbanos, eles estão dentro da cidade quase periferia, com limitação de área e produção específica. Parelheiros parece "interiorzão" mesmo (trecho entrevista Cristiano Mendes, setembro de 2011).

Para mim, aqui é uma agricultura rural, talvez periurbana, com moldes de agricultura de interior. Um rural dentro do urbano. Tem uma facilidade de acesso ao mercado, mas uma dificuldade de acesso aos programas públicos que você está com atividade rural e você não tem acesso porque é uma área urbana. O reconhecimento do poder público em relação a essa agricultura vem crescendo bastante (trecho entrevista Arpad Spauding, outubro de 2011).

O território da Subprefeitura de Capela do Socorro, onde insere-se a maior porção da APA Bororé-Colônia, é constituído de paisagens rurais, porém, a maior proximidade do aglomerado urbano, assim como a significativa incidência de ocupações antrópicas e até mesmo consolidação de bairros recentes, traria maiores incertezas acerca da reconstituição da zona rural. Com efeito, a falta de uma infraestrutura urbana estabilizada e o potencial de grandes fragmentos arbóreos podem pautar argumentações acerca de novas formas de entendimento a respeito de espaços que não configuram-se estritamente como urbano ou rural.

\subsection{AGRICULTURA E LEGISLAÇÃO MUNICIPAL}

O Plano Diretor Estratégico de 2002 reservou a Seção X para regulamentar a agricultura na escala municipal, porém a falta de um levantamento consistente das 
unidades de produção agrícola traz ao texto um caráter mais de agricultura urbana, ou seja, medidas para normatizar hortas em espaços situados no aglomerado urbano com objetivos educacionais e de laços comunitários. Abaixo está descrita a compilação de dois Artigos que subsidiam esta visão:

\section{PLANO DIRETOR ESTRATÉGICO \\ SEÇÃO X - DA AGRICULTURA URBANA}

\section{Art. 52 - São diretrizes da Agricultura Urbana:}

I - o desenvolvimento de políticas que visem o estímulo ao uso dos terrenos particulares com o objetivo de combate à fome e à exclusão social, por meio de atividades de produção agrícola urbana;

II - o desenvolvimento de política de aproveitamento dos terrenos públicos não utilizados ou subutilizados, visando à implantação de programas de agricultura urbana que tenham como objeto o combate à fome e à exclusão social e incentivo à organização associativa.

Art. 53 - São ações estratégicas da Agricultura Urbana:

I - fomentar práticas de atividades produtivas solidárias e associativas;

II - criar mecanismos que possibilitem a implementação de programa de agricultura urbana, na forma da lei.

FIGURA 34: Definição agricultura urbana

FONTE: Lei Municipal (n 13.430 de 13 de setembro de 2002)

Visando o aprimoramento da agricultura urbana e periurbana, foi criado o Programa de Agricultura Urbana e Periurbana (PROAURP), o qual serve de exemplo nacional em publicações de referência como o Panorama da Agricultura Urbana e Periurbana no Brasil e diretrizes políticas para a sua promoção (2007) lançado em parceria com a Organização das Nações Unidas para Alimentação e Agricultura (FAO), Ministério do Desenvolvimento Social e Combate a Fome (MDS), Secretaria de Segurança Alimentar e Nutricional (SESAN) e a rede (IPES/RUAF).

O Programa de Agricultura Urbana e Periurbana (PROAURP) foi implantado por iniciativa do poder municipal e com participação da sociedade civil através do Fórum de Agricultura Urbana e Periurbana da Região Metropolitana de São Paulo. Um dos objetivos do PROAURP era a criação de um Conselho de Agricultura Urbana e Periurbana em caráter deliberativo para administrar o fundo orçamentário do Programa. Porém, ocorreu uma grande desarticulação de suas lideranças advindas de mudanças na 
gestão ocasionando o veto do Conselho e a desarticulação do Fórum (SANTANDREU, 2007).

Contudo, a execução do PROAURP continuou em andamento, sendo normatizado por uma Portaria (Lei Municipal $\left.\mathrm{n}^{0} 13.727 / 2004\right)$ que foi regulamentada pelo Decreto $\left(\mathrm{n}^{\circ}\right.$ 45.665/2004), o qual aponta a consecução do Programa a um grupo executivo composto por diversas Secretarias Municipais: Secretaria do Municipal Verde e do Meio Ambiente (SVMA), a extinta Secretaria Municipal de Abastecimento (SEMAB), Secretaria Municipal do Desenvolvimento, Trabalho e Solidariedade (SDTS), Secretaria Municipal da Saúde (SMS), Secretaria Municipal das Subprefeituras (SMSP) e as Subprefeituras. De acordo com o Decreto, competia a SVMA a coordenação do grupo executivo assim como a infraestrutura técnica e administrativa; tendo como atribuição a criação de um sistema de informações agropecuárias e ambientais georreferenciadas em áreas destinadas à agricultura urbana e periurbana, educação ambiental, promoção de práticas de conservação ambiental, agroecoturismo, orientar práticas urbanas sobre tecnologias alternativas de controle de pragas e doenças com o apoio das Subprefeituras. Cabia a extinta SEMAB a orientação em relação à produção e comercialização sobretudo em feiras, mercados municipais e sacolões, tendo o apoio das Subprefeituras. A SDTS ficou responsável pelo fomento de pequenos empreendimentos agrícolas (rurais, urbanos e periurbanos) e cooperativas de crédito, também apoiada pelas Subprefeituras locais.

A falta de subsídio e infraestrutura fragilizou a execução de um programa de tamanha dimensão. Contudo, uma série de iniciativas como a criação da Casa de Agricultura Ecológica de Parelheiros, as articulações da Câmara Técnica conjunta de Agricultura e Desenvolvimento Rural Sustentável das APAs Capivari-Monos e BororéColônia e os subsídios do Fundo Especial de Meio Ambiente e Desenvolvimento Sustentável (FEMA) da SVMA, trazendo ONGs para articular o processo de transição agroecológica, fortaleceram projetos e ações ligados a agricultura na área de estudos.

Havia apenas o PROAURP, mas era apenas um programa. Para as coisas funcionarem efetivamente no serviço público você precisa ter estrutura para isso, precisa ter um setor. Agricultura em São Paulo não tinha onde, apenas um programa meio solto, pois os técnicos que trabalhavam no programa estavam organizados em várias outros locais e outras pessoas. (trecho entrevista Nadiella Monteiro, novembro 2011) 
Com efeito, a fragilidade de designar a responsabilidade de fomentar a agricultura no âmbito municipal para a SVMA, a qual tem como atribuição as questões ambientais e não a agricultura em si, foi fortalecida pelo olhar dos técnicos desta Secretaria à medida que relacionavam o uso agrícola à conservação ambiental, trazendo a agroecologia como uma potente ferramenta de conservação ambiental, principalmente, da terra e dos recursos hídricos. Como consequência, uma série de ações ${ }^{22}$ começou a ser concretizadas dando visibilidade a agricultura de caráter comercial na zona sul, especialmente no território das APAs.

A Câmara Técnica (CT) conjunta de Agricultura e Desenvolvimento Rural Sustentável dos Conselhos Gestores das APAs Capivari-Monos e Bororé-Colônia foi fundamental para a valorização e o reconhecimento da agricultura em seus territórios, protagonizando, assim, a execução de um processo de transição agroecológica na zona sul do município. Isto ocorreu por conta do olhar ambiental que os gestores e técnicos das APAs têm sobre a área que resultou na pró-atividade em fomentar ações e projetos que equalizam a agricultura e a conservação ambiental como: o manejo de baixo impacto ambiental, a proteção da qualidade dos recursos hídricos, apoio a comercialização, a promoção e o consumo consciente, o fortalecimento da agricultura familiar e a permanência do jovem na agricultura. Cabe destacar que as articulações promovidas pela CT de Agricultura junto aos agricultores, órgãos públicos e ONGs, mesmo concentrando o foco na conservação ambiental, não estão restritas aos agricultores que realizam o manejo estritamente livre de venenos e adubos sintéticos. A agroecologia deve ser um horizonte a ser alcançado, porém existem necessidades anteriores que devem ser priorizadas no processo como o acolhimento, a visibilidade, a assistência técnica e extensão rural e o apoio a comercialização; agregando assim tanto produtores convencionais, quanto produtores em processo de transição agroecológica.

Diversas ações efetivas da CT de Agricultura podem ser elencadas como: auxílio ao fomento da adequação ambiental das propriedades agrícolas; apoio a Casa da Agricultura Ecológica na realização de assistência técnica e extensão rural para

\footnotetext{
${ }^{22}$ Cabe ressaltar que eventos diversos possibilitaram este contexto, porém o foco deste capítulo é levantar elementos que rebateram diretamente no campo das políticas públicas da agricultura na área de estudos.
} 
recuperação de áreas degradadas; incubação e auxílio a operacionalização da primeira cooperativa de agricultores da região das APAs (CooperApas); captação de recursos em parceria com a CooperApas por meio da Chamada Pública do Projeto de Desenvolvimento Rural Sustentável (PDRS) estabelecido pela Secretaria do Estado do Meio Ambiente (SMA) e o Banco Mundial; organização de três Encontros de Planejamento Estratégico em Agricultura; articulação para subsidiar a capacitação agroecológica por meio do Edital do Fundo Especial de Meio Ambiente e Desenvolvimento Sustentável (FEMA); apoio a criação e regulamentação de Sistemas Agroflorestais (SAFs); incentivos diversos para a transição agroecológica.

Para isso a gente fez conseguir primeiro os editais do FEMA fechados na APA, daí que a coisa começou a mudar de figura na questão da agricultura. Outro problema: não tinham instituições na região prontas para escrever um projeto. Além de fazer todo o processo interno de conseguir viabilizar o edital, juntar recurso e conseguir aprovação, a gente teve que divulgar para instituições de fora como o ITCP, 5 Elementos, AAO da primeira leva. A gente quer a unificação das APAs e o primeiro campo que conseguimos fazer unificado foi a agricultura porque é mais comum nas duas APAs. (...) A constituição da APA foi crucial no processo de conversão. A articulação tanto institucional, quanto com a população local, os agricultores, se deu no âmbito das APAs e nas ferramentas de gestão que as APAs tinham naquele momento que era a CT de agricultura e os Conselhos Gestores. Foi ali que isso começou a surgir, e inclusive paradoxalmente, foi ali que começou a surgir a amarração institucional para isso. (...) Não havia ninguém que trabalhava com a agricultura oficialmente, não haviam agricultores em Parelheiros. Ficava nós do Verde tentando trabalhar isso que era complicado. Eu via pé de alface, eu via chuchu, a gente que não está sabendo eles estão, o que eles estão fazendo. (...) E nós enquanto APA, vimos o caráter emergencial, nós do DEPAVE-8 sempre vimos que a APA só vai dar certo quando tivermos uma economia basicamente agroecológica e turismo rural, para gente sempre foi bem claro essa diretriz. (...) A APA mostra que a gestão participativa é muito importante, é uma ferramenta que a gente está aprendendo a usar mas tem potencial. Estamos no momento vai o racha da agroecologia em relação a Prefeitura, pois nunca se teve tantos arranjos institucionais voltadas para essa questão. Tomar cuidado para não se perder e dar passos maior que a terra. Preciso trazer a cultura agroecológica para os agricultores que são os que trabalham na terra, não adianta ter um monte de arranjo institucional sem isso (trecho entrevista Felipe Spina Avino, setembro de 20110.

Os projetos subsidiados pelo Fundo Especial de Meio Ambiente e Desenvolvimento 
Sustentável (FEMA) foram fundamentais para integrar os agricultores locais e concretizar a assistência técnica e extensão rural na área de estudos, pois desde 2006 existem projetos $^{23}$ nas APAs da zona sul que fomentam práticas agrícolas com temas que vão desde assistência técnica à agricultura orgânica até a comercialização e geração de renda. O FEMA, criado pela Lei Municipal ( $\left.\mathrm{n}^{\mathrm{o}} 13.155 / 2001\right)$ e revogado pela Lei Municipal $\left(\mathrm{n}^{\circ}\right.$ 14.887/2009), consiste em um fundo oriundo de compensações ambientais e outras fontes de recurso da SVMA "destinado ao desenvolvimento de projetos que visem o uso racional e sustentável de recursos naturais, manutenção, melhoria ou recuperação da qualidade ambiental, pesquisa e atividades ambientais e o controle, fiscalização e a defesa do meio ambiente". Este recurso pode ser direcionado para Organizações Não Governamentais por meio de editais temáticos e também pode ser pleiteado por órgãos públicos, a fim de obter um maior orçamento para ações e projetos. O repasse do recurso é aprovado pelo Conselho do FEMA (CONFEMA), sendo composto pela gestão municipal, pelo Conselho Regional de Meio Ambiente, Desenvolvimento Sustentável e Cultura de Paz (CADES) e por ONGs que atuam na área ambiental.

Em 2009 foi lançado o Edital $n^{\circ} 8$ direcionado para a transição agroecológica objetivando:

contribuir para a capacitação e disseminação de sistemas de produção agroecológica, a organização e fortalecimento da agricultura familiar, a segurança alimentar e nutricional, o trabalho associativo e o desenvolvimento local sustentável em áreas públicas e privadas do município de São Paulo.

Diversas ONGs e Institutos como Associação de Agricultura Orgânica (AAO), 5 Elementos, Incubadora Tecnológica de Cooperativas Populares (ITCP/USP), Instituto Pedro Mataj (localizado na APA Capivari-Monos), Programa de Jovens da Reserva da Biosfera do Cinturão Verde (RBCV) pela Associação Holística de Participação Comunitária Ecológica (AHPCE), Associação Biodinâmica (ABD), Instituto Kairós, Instituto Mokiti Okada estiveram presentes nas APAs dando início e estruturando o processo de transição agroecológica:

Os projetos são importantes porque deram toda essa conscientização e deram toda essa base, mas para você ter uma política pública de longo prazo, ali permanente, é o que vai garantir

\footnotetext{
${ }^{23}$ Os projetos estão elencados no capítulo dois.
} 
continuidade, ele não vai sentir que acabou o projeto e estou desamparado (trecho entrevista

Cristiano Mendes, setembro 2011).

\section{PROJETOS DE AGRICULTURA SUBSIDIADOS PELO FEMA}

\begin{tabular}{|c|c|c|}
\hline Edital/Ano & Proponente & Nome do Projeto \\
\hline $003 / 2006$ & $\begin{array}{l}\text { Associação de Agricultura } \\
\text { Orgânica (AAO) }\end{array}$ & $\begin{array}{l}\text { Água doce - Extensão rural agroecológico na APA Capivari- } \\
\text { Monos }\end{array}$ \\
\hline $003 / 2006$ & Instituto Pedro Matajs & Raízes \\
\hline $004 / 2007$ & Instituto Pedro Matajs & Sementes do futuro \\
\hline 004/2007 & 5 Elementos & $\begin{array}{l}\text { Educação ambiental para incentivar a agricultura orgânica nas } \\
\text { APAS Bororé-Colônia e Capivari-Monos. }\end{array}$ \\
\hline $006 / 2008$ & Instituto Pedro Matajs & Motirõ da Jatai \\
\hline $006 / 2008$ & Instituto Pedro Matajs & Flores de mel \\
\hline $006 / 2008$ & $\begin{array}{l}\text { Associação Holística de } \\
\text { Participação Comunitária } \\
\text { Ecológica (AHPCE) }\end{array}$ & $\begin{array}{l}\text { Sistemas agroflorestais como alternativa econômica, social e } \\
\text { ambiental para agricultores e jovens - PJAPA }\end{array}$ \\
\hline $006 / 2008$ & $\begin{array}{l}\text { Associação Ninho Criança } \\
\text { Esperança }\end{array}$ & $\begin{array}{l}\text { Profissão viverista de mudas nativas e ervas medicinais - } \\
\text { Educando para o trabalho coletivo }\end{array}$ \\
\hline 007/2009 & Associação Biodinâmica (ABD) & $\begin{array}{l}\text { A educação ambiental através da cosntrução de modelos } \\
\text { agrícolas sustentáveis }\end{array}$ \\
\hline $007 / 2009$ & O Instituto Ambiental - (OIA) & Agricultura urbana \\
\hline $007 / 2009$ & SOS Represa Guarapiranga & Caoby - Boas práticas socioambientais para viver melhor \\
\hline 008/2009 & 5 Elementos & $\begin{array}{l}\text { Educação ambiental para incentivar a agricultura orgânica nas } \\
\text { APAS do Bororé-Colônia e Capivari-Monos }\end{array}$ \\
\hline 008/2009 & $\begin{array}{l}\text { Associação dos Moradores dos } \\
\text { Jd. Petrópolis e dos Estados } \\
\text { (SAJAPE) }\end{array}$ & $\begin{array}{l}\text { Programa de Compostagem - Valorização dos residuos } \\
\text { orgânicos na comunidade }\end{array}$ \\
\hline 008/2009 & Fundação Mokiti Okada (MOA) & $\begin{array}{l}\text { Prática da agricultura natural, técnica de base agroecológica, para } \\
\text { o incentivo ao uso sustentável com a produção e manutenção da } \\
\text { qualidade do solo e da água na Bacia da represa de Guarapiranga } \\
\text { para a expansão da Agricultura Urbana e Periurbana }\end{array}$ \\
\hline $008 / 2009$ & Instituto Kairós & $\begin{array}{l}\text { Fortalecimento dos canais de comercialização de produtos } \\
\text { agroecológicos e economia solidária do municipio de São Paulo, } \\
\text { através da campanha para o consumo responsável e articulação } \\
\text { de redes e pontos de comercialização }\end{array}$ \\
\hline 008/2009 & SOS Represa Guarapiranga & $\begin{array}{l}\text { Caoby economia solidária e proteção ambiental - Subprojeto: } \\
\text { Implatação de agroindústria solidária para produção de banana } \\
\text { passa orgânica }\end{array}$ \\
\hline
\end{tabular}

FIGURA 35: Projetos de agricultura - FEMA

FONTE: Secretaria Municipal do Verde e do Meio Ambiente (fevereiro de 2012) 
Em 2010, o supracitado PROAURP é regulamentado por um novo Decreto Municipal ( $\left.n^{0} 51.801 / 2010\right)$ que detalha de forma mais clara as atribuições dos órgãos públicos em relação à agricultura:

O Decreto coloca nome nos bois falando da Casa de Agricultura Agroecológica, das atribuições da ABAST, da SVMA que não compete extensão rural, Subprefeitura compete infraestrutura. Começa a ficar mais claro como você vai manter essa política pública porque está escrito lá, que está numa lei que está amparada no Plano Diretor (trecho entrevista Maria Lúcia Bellenzani, julho 2011)

Este Decreto revela o aprimoramento do olhar institucional sobre a agricultura no Município até mesmo na própria denominação de agricultura urbana e periurbana, ampliando a visão das hortas educacionais e comunitárias para as formas de comercialização agrícola:

\section{DEFINIÇÃO AGRICULTURA URBANA}

\section{PROAURP LEI MUNICIPAL No 13.727/04}

Art. $1^{\circ}$

$\S 1^{\circ}$ - Para os fins desta lei, entende-se por agricultura urbana toda a atividade destinada ao cultivo de hortaliças, legumes, plantas medicinais, plantas frutíferas e flores, bem como a criação de animais de pequeno porte, piscicultura e a produção artesanal de alimentos e bebidas para o consumo humano no âmbito do município.

\section{DEFINIÇÃO AGRICULTURA URBANA E PERIURBANA}

DECRETO PROAURP N ${ }^{\circ} \mathbf{5 1 . 8 0 1 / 1 0}$

Art. $1^{\circ}$

$\S 1^{\circ}$. Entende-se por Agricultura Urbana e Periurbana as atividades que incluem a produção e a transformação dos produtos agrícolas (olerícolas, frutas, plantas medicinais e ornamentais, inclusive de produtos advindos do agroextrativismo) e pecuários (animais de pequeno porte), com fins comerciais, educativos, medicinais ou voltados ao autoconsumo, no âmbito do Município.

FIGURA: 36 e 37: Definição agricultura urbana e periurbana FONTE: Lei Municipal (n 13.727/04) e Decreto Municipal (n 51.801/10) 
O Decreto também aponta argumentos que fundamentam a relevância e multifuncionalidade da agricultura elencando: a significativa importância da produção agrícola, o potencial de conservação ambiental dos mananciais, o fomento à segurança alimentar, as estratégias de emprego e renda, o potencial de barreira para expansão urbana, a proteção do caráter rural, além de priorizar a produção de manejo agroecológico. A execução do PROAURP foi reorientada no artigo 3 da seguinte forma: a SVMA terá a atribuição, por meio da Escola de Jardinagem e seus Núcleos de Gestão Descentralizada, de implantar hortas com orientação técnica agroecológica para fins educativos e de autoconsumo, fomentando assim práticas estritamente de agricultura urbana; além de criar um sistema de informação agropecuária e ambiental georreferenciado em parceria com a ABAST. A SMSP, por meio da Supervisão Geral de Abastecimento (ABAST), é responsável pela assistência técnica agroecológica voltada a comercialização, principalmente no território periurbano onde se localiza as unidades de produção agrícolas voltadas para produção comercial; além de apoiar a venda de produtos de agricultores urbanos e periurbanos em feiras, mercados municipais e sacolões. As Subprefeituras ficam responsáveis pelo suporte de infraestrutura e materiais.

Com a regulamentação dessa lei por Decreto, a gestão desse programa ficou na SVMA trabalhando com escolas e hortas comunitárias. Agricultura mais comercial, principalmente no extremo sul, nunca teve uma atenção maior porque historicamente quem tem que cuidar disso é o Estado. Assitência técnica no Brasil inteiro é estadual, CATI. (trecho entrevista Nadiella Monteiro, novembro de 2011)

Outro item fundamental do Decreto é a indicação para implantação de três Casas de Agricultura Ecológica com o objetivo de fornecer apoio e assistência técnica agroecológica aos agricultores das zonas sul, leste e norte. A Casa de Agricultura Ecológica de Parelheiros foi criada pelo Decreto Municipal ( $\left.\mathrm{n}^{\circ} 47.280 / 06\right)$ e cunhada com o nome José Umberto Macedo Siqueira, falecido agricultor da zona sul. A unidade Leste e a unidade Norte ainda estão sendo implantadas. Cabe destacar que existem unidades de produção agrícola para comercialização em menor número nas zonas leste e norte, mas com características bem diferentes da aptidão rural da zona sul do município. As Casas de Agricultura Ecológica estão sob responsabilidade da SMSP por meio da Supervisão de Abastecimento (ABAST) e através do Departamento de Agricultura e Abastecimento 


\section{denominado pelo presente Decreto.}

Com a mudança do Decreto foi alterado o nome do Departamento de Abastecimento e Agricultura. Ter esse nome tem dupla função: reconhecimento e possibilidade de ter convênio com outros níveis de governo (trecho entrevista Nadiella Monteiro, novembro de 2011).

Este importante Decreto faz parte do conjunto de ações que serviram para sedimentar a agricultura como política pública do município de São Paulo como orientado abaixo:

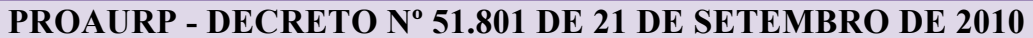

\section{Art. 1}

I - a produção local e os programas de autoabastecimento alimentar, tais como hortas comunitárias, escolares e domésticas, bem como pomares e pequenos criatórios comunitários, com a finalidade de garantir a segurança alimentar, a geração de emprego e renda e a inclusão social;

II - o desenvolvimento da agricultura comercial, com o oferecimento de assistência técnica e incentivo aos pequenos e microempreendimentos pesqueiros, agrícolas, agroindustriais e criatórios de animais, propiciando o intercâmbio de experiências e a realização de boas práticas agrícolas e ambientais;

III - a organização dos agricultores familiares, apoiando a compra direta de seus produtos, o acesso ao crédito e aos programas oficiais de incentivo à produção;

IV - a organização de pequenos varejistas e feirantes, articulando-os com os agricultores familiares;

$\mathrm{V}$ - as iniciativas locais, cooperativadas, associativas e comunitárias, por meio do fomento de atividades que propiciem qualificação de mão-de-obra e organização de grupos geradores de emprego e renda, favorecendo a gestão participativa e priorizando a geração de empreendimentos de autogestão;

VI - o desenvolvimento de alimentos e bebidas artesanais, que valorizem a produção local e os hábitos culturais dos produtores, como meio de incentivo ao agroecoturismo;

VII - as feiras de produtos oriundos da Agricultura Urbana e Periurbana, referidos no $\S 1^{\circ}$ do artigo $1^{\circ}$ deste decreto, bem como a criação de entrepostos regionais e outros equipamentos destinados à venda direta ao consumidor, incentivando a produção e o comércio locais, com o intuito de baratear os preços e aproximar organizações de produtores e consumidores;

VIII - a ocupação regular de áreas ociosas, aumentando a permeabilidade do solo em Zona Urbana e garantido a produção de água em região de proteção aos mananciais, com a manutenção do caráter rural das áreas classificadas como ZEPAG, evitando, assim, a constituição de loteamentos irregulares.

FIGURA 38: PROAURP

FONTE: Decreto Municipal (n 51.801/10) 
Outro importante instrumento público no auxílio ao processo de transição agroecológica na área de mananciais é o Protocolo Guarapiranga, o qual consiste em um termo de adesão conjunta sediado entre os agricultores e o poder público através da Secretaria Estadual de Meio Ambiente (SMA), da Secretaria Estadual da Agricultura e do Abastecimento (SAA), da Secretaria Municipal do Verde e Meio Ambiente (SVMA) e da Secretaria de Coordenação das Subprefeituras (SAA) objetivando a adequação ambiental de propriedades agrícolas estabelecidas nas áreas de mananciais do município paulistano.

Este protocolo foi iniciado no município em 2010, através do Programa Estadual Guarapiranga Sustentável, pois já haviam iniciativas municipais na capital para o processo de transição agroecológica como relatado em entrevista:

O protocolo é uma das ações que está dentro do projeto Guarapiranga Sustentável, que abrange 7 município da bacia do Guarapiranga. A ideia do Protocolo já é um instrumento utilizado por outros setores e outras políticas da Secretaria de Agricultura e Meio Ambiente. (...) Existia uma demanda de trabalhos dessas regiões de mananciais, ações estratégicas para desenvolver a agricultura sustentável dentro dessas região e a gente começou fazendo uma política pela Guarapiranga porque é uma região que tem vários problemas juntos. Dentre as ações do projeto estão essa coisa da transição agroecológica via protocolo de boas práticas, mas tem outras ações também como a rede de agroecologia da Guarapiranga, ações pra promover assistência técnica e outras ações. A ideia é que tivesse um protocolo único para Guarapiranga inicialmente envolvendo os 7 município, mas nem todos tiveram o mesmo interesse que a Prefeitura de são Paulo (trecho entrevista Wilson Tivelli, outubro de 2012)

$\mathrm{O}$ agricultor que aderir voluntariamente recebe um Selo de Procedência que atesta sua transição agroecológica e permite comercializar nas feiras fomentadas pelo programa municipal de Agricultura Limpa. É importante ressaltar que se cria uma nova tipologia estratégica que não é o produtor convencional e nem o produtor orgânico, mas sim o produtor em transição. Esta tipologia é fundamental para fortalecer o complexo processo do agricultor quando está em fase de transição, visto que a conversão para o manejo agrícola é feita em um lento processo que pode perdurar por anos até o produtor conseguir uma certificação orgânica. Por este motivo, existem nas feiras orgânicas do município agricultores com certificação orgânica e outros que estão ajustando sua produção ao manejo orgânico. 
O Protocolo Guarapiranga prevê um plano de conversão para o orgânico que é acompanhado mensalmente pelos técnicos da Casa da Agricultura Ecológica. Este plano é pontuado através de um check list (checagem) que pontua se o agricultor está cumprindo ou não as normas do plano.

\begin{abstract}
Nós temos aqui o que é esse check list. Ele é feito de uma forma que algumas ações que o produtor desenvolve coloca ele num nível bem baixo, por exemplo, se ele utiliza agrotóxico está no nível 1, sem direito inclusive de receber o selo de origem da região que é o Selo Guarapiranga fornecido pela Prefeitura. É um trabalho que está sendo feito primeiro levantando esse check list, encontrando onde estão as limitações para agroecologia. E depois é feito um plano de conversão dessa propriedade. (...) A assistência é feito através da casa de agricultura ecológica municipal de Parelheiros (trecho entrevista Araci Oyama, outubro de 2012)
\end{abstract}

A checagem apresenta uma série de perguntas a fim de identificar se o agricultor caracteriza-se como familiar; possui Declaração de Aptidão ao PRONAF (DAP); a situação da propriedade (própria, arrendada, cedida ou emprestada, posse); informações sobre o uso do solo como cultura anual, hortaliças, estufas, fruticultura, plantas ornamentais, sistemas agroflorestais, produção animal, pastagem, nascentes, cursos d'água, reservatórios, área de mata em APP, área de reflorestamento, relevo de acordo com classe de declividade; também acerca de fertilizantes (adubos) químicos, fertilizantes (adubos) orgânicos (esterco, biofertilizantes preparados e outros), agrotóxicos (herbicidas, fungicidas, inseticidas), destino das embalagens e procedimentos. O produtor é classificado de acordo com a pontuação:

- Pontuação positiva: caminhos com distribuição racional; caminhos vegetados; escoadouro; bacias de retenção de água da chuva e/ou irrigação; terraços, curva de nível, cordão vegetado; plantio em nível; pousio vegetado; adubação verde; esterco produzido na propriedade; uso de biofertilizantes; rotação de culturas; reposição de matéria orgânica do solo; cercas vivas; manejo vegetal espontâneo por meio não químico; integração entre produção animal e vegetal; cultivo de alimento para consumo próprio; sistema agroflorestal; reflorestamento; análise química do solo feita periodicamente; calagem baseada em análise do solo; adubação feita com base na análise do solo; substituição fertilizantes químicos 
nos últimos doze meses; irrigação registrada por cultura e área; outorga para área explorada; práticas de aumento da eficiência de irrigação; controle de pragas e doenças por meios agroecológicos; mata ciliar presente e protegida; nascentes protegidas conforme legislação vigente; dejetos humanos tratados; lixo seco separado para reciclagem; lixo úmido adequado para compostagem; lixo úmido não adequado para compostagem recolhido por coleta pública; cobertura do solo; ausência de erosão; regularização fundiária, fontes de energia alternativa;

- Pontuação negativa: prática de queimadas; vazamento de água no sistema de irrigação; embalagens vazias e/ou com restos de agrotóxicos.

Houveram apenas quatro casos de desistência que foram justificados pela mudança de ocupação do produtor, mudança de área e por produtores que não compreende os benefícios do protocolo.

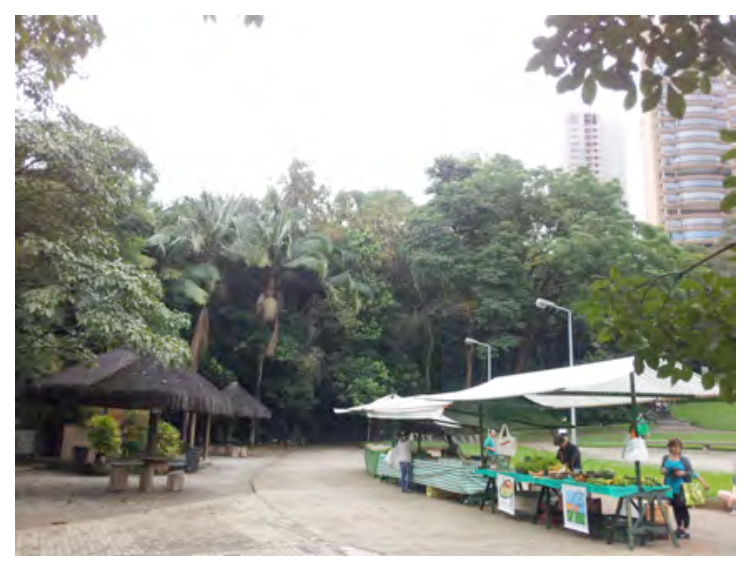

FIGURA 39: Feira Semanal do Programa Municipal Agricultura Limpa no parque Burle Marx REGISTRO FOTOGRÁFICO: Simone Miketen (agosto 2012)

A barraca contém a imagem do Selo Protocolo Guarapiranga à esquerda e do Programa Agricultura Limpa à direita

\subsection{OS CAMINHOS POSSÍVEIS}

Neste capítulo foram apresentados argumentos que, muito distantes de responderem a questão, podem servir para trazer visibilidade a possíveis rumos ao fortalecimento da agricultura no extremo sul de São Paulo, além da ampliação do debate que necessita de muito engajamento e vontade política para efetivas medidas concretas. Pelo fato de existirem poucos estudos específicos, as entrevistas com técnicos do poder 
público e a consulta à legislação foram fundamentais na tentativa de clarear pontos críticos que emergem da área de estudos. O grande destaque é que as instâncias municipais estão protagonizando este processo com a criação de modelos que podem contribuir para valorizar o desenvolvimento de atividades agrícolas nas cidades e seus entornos próximos, assim trazendo experiências e esperança para o verdejar da infraestrutura urbana pautado em alimentos de qualidade. 


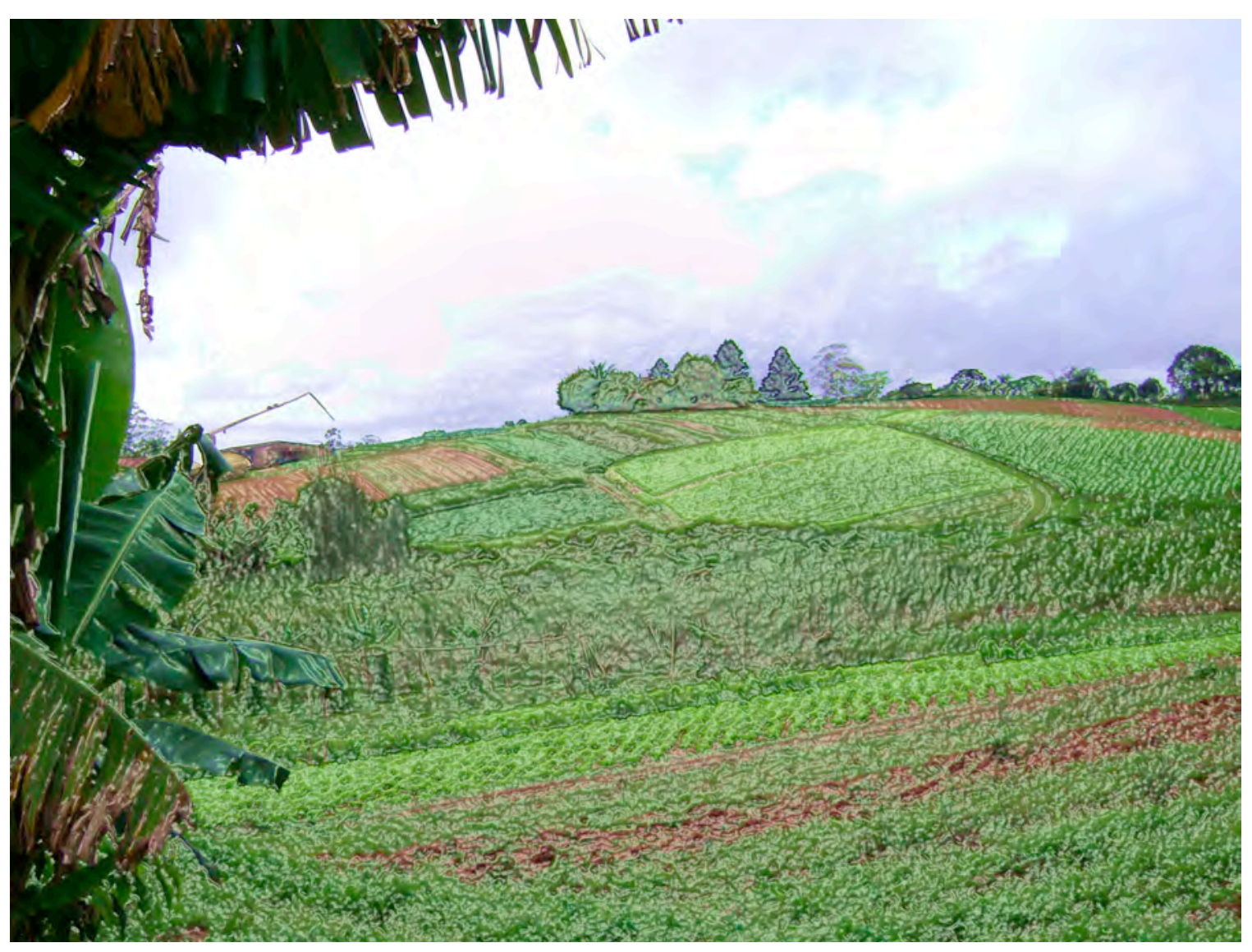

capítulo 3 - AS CULTURAS DA TERRA 


\subsection{INTRODUÇÃO}

Diversos resultados e ações estratégicas foram levantados, pela presente pesquisa, acerca do processo de transição agroecológica em andamento nas áreas de mananciais que compõem o extremo sul da capital paulista. Contudo, a investigação ganha uma maior dimensão ao aproximar-se dos(as) agricultores(as) locais com o propósito de apresentar as visões de mundo e as vozes das pessoas que vivem da terra e na terra, assim trazendo peculiares interpretações repletas de riquezas em relação: ao ambiente que habitam, à forma que cultivam os desenhos agrícolas e às maneiras que enxergam a interferência do poder público no desenvolvimento agrícola da região.

\subsection{OLHARES PROFUNDOS}

A complexidade do universo amostral da presente pesquisa científica foi descrita no capítulo anterior por meio dos arranjos institucionais, os quais subsidiaram a organização da grande quantidade de diferenciações entre os perfis dos agricultores locais. Estes foram agrupados em tipologias para fins de interpretação de dados secundários e levantamentos em campo, sendo (1) produtores cadastrados no mapeamento georreferenciado realizado em conjunto pela ABAST e SVMA, (2) beneficiários dos projetos FEMA, (3) produtores que aderiram ao Protocolo Guarapiranga, (4) integrantes da cooperativa CooperApas, (5) certificados orgânicos. Estas tipologias estão ilustradas e descritas abaixo: 
TIPOLOGIAS GRUPOS AGRICULTORES

\section{PRODUTORES MAPEAMENTO GEORREFERENCIADO ABAST-SVMA}

critério de seleção dos agricultores

Integrar as unidades de produção agrícola localizadas na zona sul do município de São Paulo.

definição

Em 2010, foi realizado um mapeamento georreferenciado das unidades de produção agrícolas abrangendo as zonas sul, leste e norte do município de São Paulo. Deste levantamento foi gerada a base de dados mais atualizada das propriedades agrícolas contendo dados das respectivas produções. Há previsão que existe pelo menos o dobro de unidades de produção agrícolas no município ainda não mapeadas.

\section{resultado}

Mapeamento municipal oficial das unidades de produção agrícola de São Paulo.

número aproximado de agricultores

Município de São Paulo: 400

Zona Sul: 320

APA Bororé-Colônia: 60

procedimentos metodológicos de pesquisa

Coleta de dados secundários

FIGURA 40

\section{BENEFICIÁRIOS PROJETOS FEMA}

\section{critérios de seleção dos agricultores}

Unidades de produção agrícola localizadas nas APAs Bororé-Colônia, Capivari-Monos e entorno.

\section{definição}

O Fundo Especial de Meio Ambiente e Desenvolvimento Sustentável (FEMA), proveniente de compensações ambientais e recursos da Secretaria do Verde e do Meio Ambiente (SVMA), desde 2006 subsidiou projetos de ONGs voltados para capacitação técnica agroecológica de unidades agrícolas localizadas nas APAs Bororé-Colônia, Capivari-Monos e entorno.

resultado

Fomento ao processo de transição agroecológica por meio de capacitações e assistência técnica.

número aproximado de agricultores

Zona Sul: 36

APA Bororé-Colônia: 5

procedimentos metodológicos de pesquisa

Coleta de dados secundários e acompanhamento de capacitações

FIGURA 41 


\section{PRODUTORES QUE ADERIRAM AO PROTOCOLO GUARAPIRANGA}

\section{critérios de seleção dos agricultores}

Unidades de produção agrícola localizadas nas áreas de mananciais da sul do município de São Paulo.

\section{definição}

O Protocolo Guarapiranga, iniciado em 2010, é um termo de adesão conjunta entre os agricultores e Secretarias municipais (SMSP e SVMA) e Estaduais (SMA e SAA) a fim de firmarem parceria para a realização de um plano de conversão agroecológico nas propriedades agrícolas localizadas nas áreas de mananciais da zona sul do município.

\section{resultado}

Assistência técnica pública agroecológica;

Selo de Procedência;

Comercialização em feiras.

número aproximado de agricultores

Zona Sul: 40

APA Bororé-Colônia: 7

procedimentos metodológicos de pesquisa

coleta de dados secundários e visita às feiras.

FIGURA 42

\section{INTEGRANTES COOPERAPAS}

\section{critérios de seleção dos agricultores}

Integrar unidades de produção agrícola localizadas na zona sul do Município de São Paulo.

definição

A Cooperativa Agroecológica dos Produtores Rurais e de Água Limpa da Região Sul de São Paulo (CoperApas) foi fundada em junho de 2011 com o objetivo, firmado em estatuto, de produção, revenda, processamento, distribuição e comercialização de produtos agropecuários e artesanato, bem como a compra e venda de insumos, materiais e equipamentos necessários à produção.

resultado

Organização dos agricultores locais para comercialização de seus produtos.

número aproximado de agricultores

zona sul: 30

APA Bororé-Colônia: 4

\section{procedimentos metodológicos de pesquisa}

Coleta de dados secundários e acompanhamento de reuniões

FIGURA 43 


\section{CERTIFICADOS ORGÂNICOS}

critério de seleção dos agricultores

Participação no projeto FEMA realizado pelo proponente ABD.

definição

Por meio da realização pela Associação Biodinâmica (ABD) de um projeto subsidiado pelo FEMA em 2011, alguns agricultores locais conseguiram certificar suas produções orgânicas dentro das conformidades do processo de certificação participativa.

resultado

Certificação dos agricultores locais para venda de produção no mercado orgânico.

número aproximado de agricultores

Zona Sul: 7

APA Bororé-Colônia: 1

procedimentos metodológicos de pesquisa

Coleta de dados secundários e acompanhamento de visitas técnicas

FIGURA 44

ORGANIZAÇÃO: Simone Miketen

A análise dos dados secundários foi iniciada pelo mapeamento georreferenciado das unidades de produção agrícola com o intuito de espacializar e categorizar a atividade agrícola no extermo sul. Por se tratar de uma pesquisa qualitativa, a amostragem definida foi a não probabilística por tipicidade, ou seja, foi esquadrinhado subgrupos representativos do universo de agricultores locais orientados pelos objetivos e hipóteses (GIL, 2004, p. 89), sendo:

- subgrupo (1) de produtores(as) agrícolas contemplados por projetos e ações do poder público frente ao processo de transição agroecológica;

- $\quad$ subgrupo (2) de produtores(as) agrícolas não contemplados por projetos e ações do poder público frente ao processo de transição agroecológica.

Foram selecionados as unidades de produção agrícolas localizadas no território da APA Bororé-Colônia. O primeiro subgrupo de agricultores selecionados surgiu do cruzamento das diferentes tipologias ordenadas abaixo: 


\section{MAPEAMENTO GEORREFENRENCIADO - ABAST/SVMA \\ PRODUTORES LOCALIZADOS NA APA BORORÉ-COLÔNIA}

\begin{tabular}{|c|c|c|c|c|c|}
\hline LOCALIZAÇÃO & PRODUTORES AGRÍCOLAS & FEMA & PROTOCOLO & COOPERAPAS & CERTIFIC \\
\hline S-006 & Ademir Bueno Reimbers & & $\mathrm{X}$ & & \\
\hline S-008 & Agenor Emidio Pereira & & & & \\
\hline S-010 & Alberto Takashi Shida & & & & \\
\hline S-020 & Anselmo Borges Pereira Jorge & & & & \\
\hline S-041 & Avelino Reimberg & & & & \\
\hline S-044 & Benedito Guinguer Helfstein & $\mathrm{X}$ & $\mathrm{X}$ & & \\
\hline S-058 & Daniel Guilguer Helfstein & & & & \\
\hline S-071 & Eduardo Tetsuro Kitagami & & & & \\
\hline S-079 & Fernando Sonnewend & & & & \\
\hline S-083 & Fujiko Murakami & & & & \\
\hline S-089 & Gustavo Fowler & & & & \\
\hline S-090 & Harukyo Yamamoto & & & & \\
\hline S-100 & Hitoshi Okamoto & & & & \\
\hline S-101 & Horácio Augusto Caseiro & & & & \\
\hline S-108 & Issao Chaki & & & & \\
\hline S-113 & Joao Bizarria De Lima & & & & \\
\hline S-120 & Joao Inoue & & & & \\
\hline S-123 & Joaquim Santos & & & & \\
\hline S-135 & Jose Dos Santos & & & & \\
\hline S-145 & José Massao Okamoto & & & & \\
\hline S-150 & Jose Zellis Silva & & & & \\
\hline S-158 & Kazuyochi Nakao & & & & \\
\hline S-163 & Lia Goes De Moura & & $\mathrm{X}$ & $\mathrm{X}$ & \\
\hline S-189 & Mário Kaziuki Inoue & & & & \\
\hline S-191 & Mario Minami & & & & \\
\hline S-193 & Mario Tadashi Nakamura & & & & \\
\hline S-199 & Masami Tashiro & & & & \\
\hline S-198 a S-201 & Massue Shirazawa & $\mathrm{X}$ & $\mathrm{X}$ & $\mathrm{X}$ & \\
\hline S-200 & Masatoshi Shirasawa & & & & \\
\hline S-202 & Massaro Katayama & & & & \\
\hline S-204 & Mauricio Bueno Dos Santos & & & & \\
\hline
\end{tabular}




\begin{tabular}{|c|c|c|c|c|c|}
\hline S-208 & Michael Ludewigs & & & & \\
\hline S-213 & Mitsuji Nakagama & & & & \\
\hline S-214 & Mitsuo Katayama & & & & \\
\hline S-218 & Nelson Saburo Shimozomo & & & & \\
\hline S-231 & Paulo Yoshinabo Matsumora & & & & \\
\hline S-234 & Pedro Glasser Bueno & & & & \\
\hline S-236 & Pedro Pieroni Neto & & & & \\
\hline S-243 & Ricardo Y. Nakamura & & & & \\
\hline S-246 & Roberto Noburo Tsuchiya & & & & \\
\hline S-247 & Roberto Zimbardi & & & & \\
\hline S-251 & Rutnéia Maria Rodrigues Rotta & $\mathrm{X}$ & & & \\
\hline S-257 & Maria José Kunikawa (Tomico) & $\mathrm{X}$ & $\mathrm{X}$ & $\mathrm{X}$ & $\mathrm{X}$ \\
\hline S-259 & Sergio Nagao & & & & \\
\hline S-265 & Shigueo Katayama & & & & \\
\hline S-263 & Shiguemi Tsutumi & & & & \\
\hline S-270 & Sohan Higa & & & & \\
\hline S-279 & Tamotsu Shimoyama & & & & \\
\hline S-285 & Tsukasa Takahara & & & & \\
\hline S-288 & Ubirajara Galdino Munichslofer & & $\mathrm{X}$ & & \\
\hline S-291 & Valdomiro Kazumo Matsumura & & & & \\
\hline S-292 & Valdomiro Matsumura & & & & \\
\hline S-293 & Valéria Maria Macorati & $\mathrm{X}$ & $\mathrm{X}$ & $\mathrm{X}$ & \\
\hline S-296 & Waldemir Rodrigues De Oliveira & & & & \\
\hline S-298 & Waldomiro Furuya & & & & \\
\hline S-301 & Wilson Hessel Roshel & & & & \\
\hline S-304 & Yoji Toyoshi Nagao & & & & \\
\hline S-306 & Yoshiharu Matsumura & & & & \\
\hline S-307 & Yoshime Nakagawa & & & & \\
\hline S-308 & Yoshitaka Ogata & & & & \\
\hline
\end{tabular}

FIGURA 45: Cadastro agricultores localizados na APA Bororé-Colônia (agosto 2011)

ORGANIZAÇÃO: Simone Miketen 


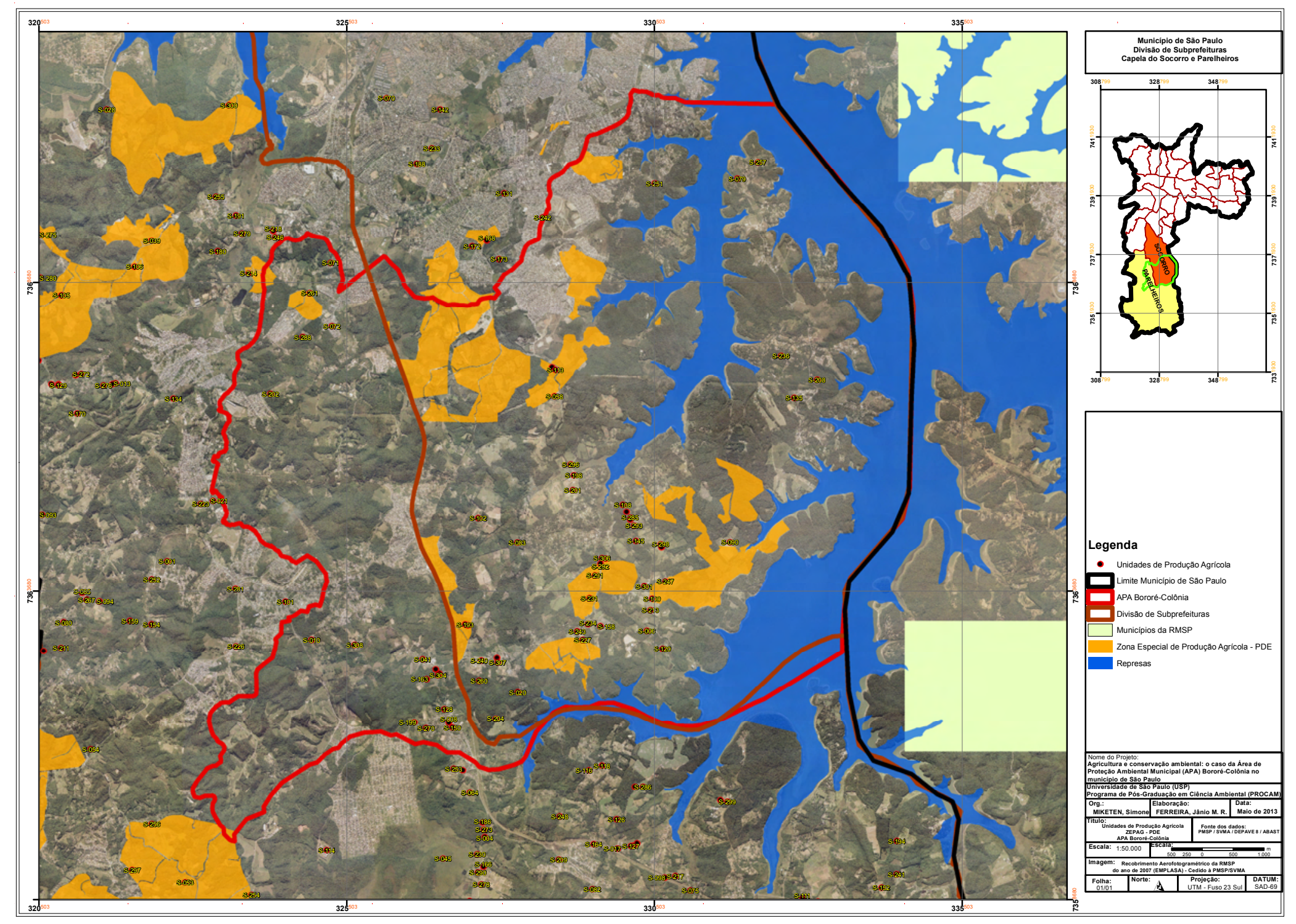


O mapeamento georreferenciado ABAST/SVMA vem sendo aprimorado pelos órgãos competentes porque algumas informações não apresentam padrões claros para análise interpretativa. Entretanto, este material serve de apoio para avaliar que cerca de $13 \%$ dos agricultores localizados na APA Bororé-Colônia foram contemplados por ações do poder público em relação ao processo de transição agroecológica que está em andamento na zona sul do município. No total de 60 (sescenta) agricultores existem: 5 (cinco) que participaram das capacitações dos projetos FEMA, 7 (sete) que aderiram ao Protocolo Guarapiranga, 4 (quatro) que fazem parte da cooperativa CooperApas e 1 (um) possui certificação orgânica.

\subsection{VOZES DO CAMPO}

A segunda etapa dos procedimentos metodológicos foi o levantamento em campo nas unidades de produção agrícolas do subgrupo agricultores beneficiados, os quais eram produtores subsidiados pelos projetos FEMA, aderiram ao Protocolo Guarapiranga, participavam da CooperApas e obteram certificação orgânica. Por meio do cruzamento da listagem de participantes destes programas, foram encontrados quatro produtos agrícolas que foram contemplados na APA Bororé-Colônia: Dona Massui Shirasawa, Maria José Kunikawa (Tomi), Benedito Guilguer Helfstein e Valéria Maria Macoratti. Foi agregado ao primeiro subgrupo o produtor José Luiz da Silva (Zé da Floresta) porque, mesmo localizada fora do perímetro da APA Bororé-Colônia, sua propriedade está situada a menos de 1 quilómetro de seu limite e sua propriedade foi contemplada em todos os itens listados acima. Porém, sua maior relevância no universo amostral está no fato de apresentar práticas de manejo particulares baseadas no sistema agroflorestal, assim totalizando cinco produtores.

Foram realizadas visitas nestas cinco propriedades para a realização de análise qualitativa através da observação participante, objetivando o conhecimento do cotidiano destes agricultores localizados em áreas que resistiram à pressão constante da expansão urbana e resguardam um ritmo de produção agrícola para comercialização.

As visitas seguiam procedimentos de campo que se iniciavam com a apresentação da pesquisadora, em seguida era pedido para o agricultor caminhar pela propriedade 
contando seu histórico naquela propriedade. A entrevista sempre foi realizada de maneira descontraída, com poucas perguntas e a pesquisadora apenas intervia se assunto desviasse da pauta. Normalmente após a caminhada, a pesquisadora era convidada para um café ou almoço onde a conversa prosseguia. Adiante o agricultor recebia o convite para realizar suas atividades cotidianas enquanto a pesquisadora tirava fotos e observava o cotidiano. Nestas entrevistas realizadas por pautas, foram procuradas respostas para as seguintes questões:

1. Origem do agricultor

2. Tamanho da propriedade

3. Modalidade de uso

4. Destinação da comercialização

5. Tipo de manejo

6. Produção

7. Maquinário

Também entravam como temas a abordagem de questionamentos acerca da realidade urbana e/ou rural do bairro, como ocorreu a iniciativa do manejo orgânico e qual a influência do poder público. O tratamento dos dados coletados iniciou com a transcrição completa das entrevistas e os principais temas contidos nestas. Como resultado foi levantada a perspectiva do agricultor e, posteriormente, foi feito um cruzamento com a entrevista de outros produtores com critérios de comparação. Após o tratamento dos dados brutos, este material subsidia as deduções lógicas ou inferências para interpretação de causas, consequências, intenções e outros (BARDIN, 1973, p. 48). As principais categorias analíticas elencadas foram:

- Olhar do agricultor sobre região onde mora;

- Olhar do agricultor sobre o tipo de manejo;

- Olhar do agricultor sobre a atuação do poder público.

As categorias servem para organizar as conclusões a partir de um único princípio de classificação (GIL, 2004, p. 157) e para decifrá-las. Gil (2004, p. 156) faz uma interessante distinção entre análise e interpretação, sendo o propósito da primeira 
organizar os dados para fornecimento de respostas ao problema científico e interpretar teria como objetivo conectar o sentido das respostas com outros acontecimentos anteriores levantados. Adiante segue a descrição e resultados dos dados coletados nas visitas de campo.

\section{SEU BENEDITO GUILGUER REIMBERG}
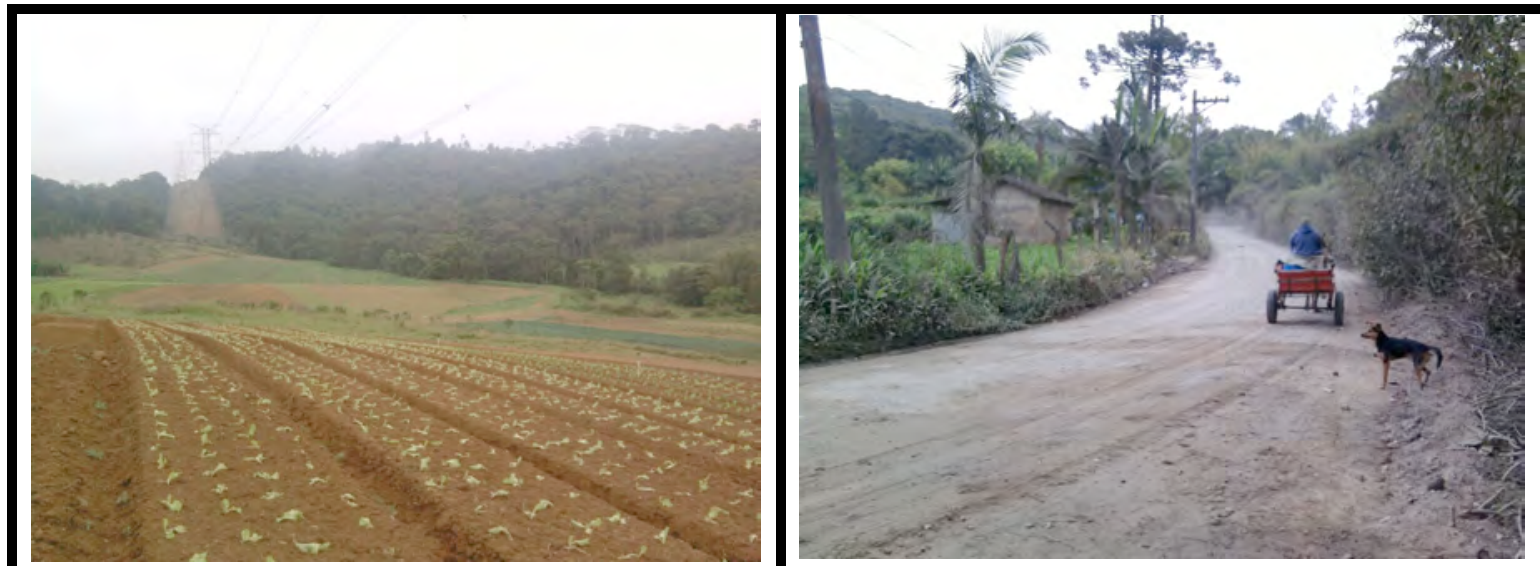

FIGURA 46

REGISTRO FOTOGRÁFICO: Simone Miketen (setembro 2011)

Propriedade do seu Benedito

\section{FIGURA 47}

REGISTRO FOTOGRÁFICO: Simone Miketen (setembro 2011) Avenida Paulo Guilguer Reimberg

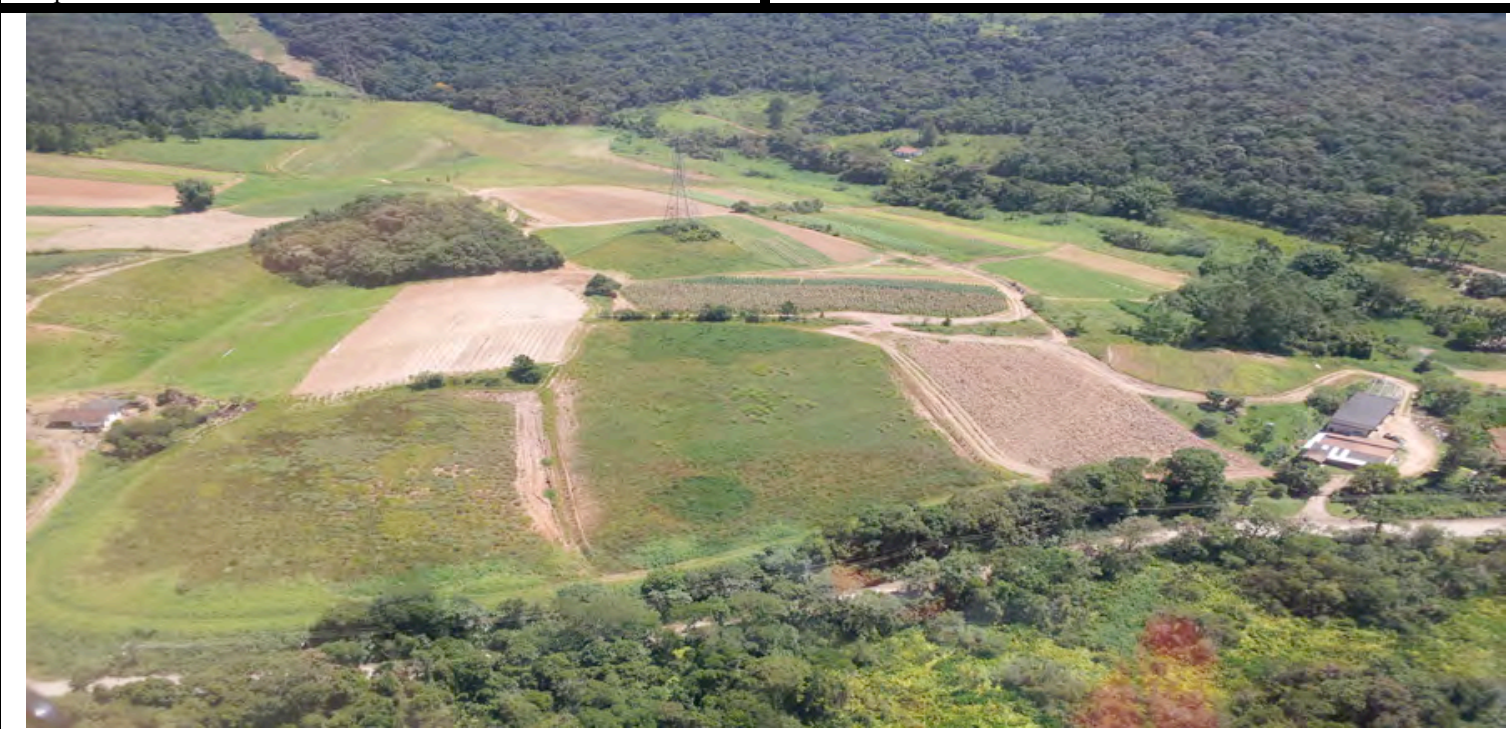

\section{FIGURA 48}

REGISTRO FOTOGRÁFICO: Simone Miketen (março 2013)

Propriedade de seu Benedito localizada na frente da portaria do Parque Natural Municipal Varginha 


\begin{tabular}{l|l}
\hline ORIGEM & nasceu na área que foi ocupada por seu bisavô \\
\hline TAMANHO PROPRIEDADE & 14,6 ha \\
\hline MODALIDADE DE USO & proprietário \\
\hline DESTINAÇãO PRODUÇÃO & varejo local e CEASA \\
\hline TIPO DE MANEJO & convencional e pequena área de experimentação orgânica \\
\hline ALGUNS PRODUTOS & $\begin{array}{l}\text { alface, acelga, beterraba, cebolinha, chicória, couve, couve-flor, } \\
\text { milho, repolho }\end{array}$ \\
\hline MAQUINÁRIO & 3 tratores \\
\hline RENDA AGRÍCOLA & $80 \%$ \\
\hline ENDEREÇO & $\begin{array}{l}\text { Sítio Córrego } \\
\text { Av. Paulo Guilguer Reimberg, 6094 }\end{array}$ \\
\hline ÁREA REFLORESTADA & não \\
\hline PROJETOS FEMA & ABD \\
\hline PROTOCOLO GUARAPIRANGA & sim \\
\hline COOPERAPAS & não \\
\hline CERTIFICAÇÃO & $\begin{array}{l}\text { não } \\
\text { interesse pelo manejo orgânico, diferentemente de seu filho } \\
\text { Edson que participa das capacitações e tem uma pequena área de } \\
\text { experimental orgânica. }\end{array}$ \\
\hline MANEJO AGROECOLÓGICO & esterco de vaca e biofertilizante \\
\hline
\end{tabular}

O trabalho de campo nas propriedades agrícolas foi iniciado pela curiosidade aguçada da pesquisadora em conhecer a produção de um descendente da Colônia Alemã que foi batizado com o sobrenome germânico mais famoso da região: o agricultor seu Benedito Guilguer Reimberg. Sua propriedade localiza-se no bairro Chácara Santo Amaro em uma paisagem predominantemente rural. A estrada de terra que passa em frente à sua propriedade é uma das principais vias do bairro chamada avenida Paulo Guilguer Reimberg. A chegada no sítio foi recepcionada por um gole de café e uma prosa na frente da entrada da casa, a qual chamou atenção por sua simplicidade que contrastava com a diversidade de tratores, caminhões e equipamentos agrícolas existente na 
propriedade. Logo via-se a valorização da agricultura, pois a existência de três tratores e dois caminhões mostrava que os investimentos vão exclusivamente para a lavoura. $\mathrm{O}$ maquinário, porém, era antigo mostrando que há muitos anos não havia investimentos em melhorias, provavelmente por não representar a época mais próspera da produção.

A entrevista foi iniciada com o contexto genealógico de sua família através da descrição de como ocorreu a ocupação da área e as grandes extensões de terra que antigamente estava sob propriedade de sua família. Ao definir os tempos atuais e a pressão da expansão urbana, seu Benedito diz que seu bairro é interior, mas é São Paulo. O sotaque caipira logo abrasileirava os olhos azuis de descendência germânica. Suas respostas eram pontuais e de poucas palavras, mas logo surpreendeu por sua definição de orgânico:

Orgânico é o seguinte você não pode usar esses venenos forte e tem um tipo de produto que você vai ponhá para combater os bichos. E diz que é uma lavoura que não prejudica a saúde, entendeu? Inclusive tem umas feira aí, inclusive em Santo Amaro, que é só orgânico. Só que a lavoura orgânica é muito mais feia que a convencional porque você não pode usar essas coisa. E diz que a turma vai e compra e paga caro e não fala nada. Porque eles sabem que não tem agrotóxico. Diz que não pode usar esses adubos químicos (trecho entrevista Benedito Guilguer Reimberg, setembro de 2011).

Foi fácil perceber que chamava mais a atenção de seu Benedito o fato de pagarem mais caro por um produto feio do que os efeitos positivos que o orgânico traz para a saúde. Contudo, ao ser questionado acerca dos motivos que vêm sendo estabelecidos para a produção orgânica na região, seu Benedito disse que a agricultura normal estraga a água e o orgânico ajuda na água e na terra. Seu Benedito afirma que antes da presença de técnicos dos projetos subsidiados pelo FEMA nunca tinha ouvido falar sobre orgânicos na região. Ao ser perguntado acerca dos motivos que o levaram a experimentar o orgânico, ele ressalta que está tentando porque existe apoio e acompanhamento para isso. Mesmo assim, deixou para seu filho a responsabilidade do canteiro experimental de orgânicos porque não vê vantagens na mudança de manejo em sua propriedade.

Porque eles estão tentando ajudar a gente a fazer. A gente tá tentando pra ver se dá. Porque diz que daqui há quatro anos não pode fazer mais nada desse convencional. (...) Sei lá, vamos ver se vai funcionar. Sei lá. Não posso dizer nada porque não tô coiendo nada. Prantamo um pouco de alface, um pouco de brócolis. (...) Foi o Arpad. Ele que 
começou, ele que veio falar com a gente. Antes eu nem tinha ouvido falar. A Massui começou na mesma época que a gente. Aqui ninguém falava de orgânico. Fomos no interior em umas chácaras de orgânico. Prantavam tudo que a gente prantava e vendia no parque da Água Branca (trecho entrevista Benedito Guilguer Reimberg, setembro de 2011).

Com o intuito de aprofundar o entendimento sobre o processo de transição na propriedade, o filho de seu Benedito chamado Edson (mais conhecido como Edinho) foi convidado a participar da entrevista e aceitou prontamente. A conversa aconteceu dentro da casa com mais um gole de café. Edson é um rapaz jovem que auxilia o pai na lavoura e apresenta grande discernimento e interesse sobre o manejo orgânico:

Gosto de ser agricultor. Tem que gostar. O orgânico é mais um motivo para continuar aqui. (...) Porque é diferente disso aqui. $\mathrm{Na}$ convencional a gente trabalha e a gente é tipo explorado. A gente vende e a pessoa faz mais que o dobro da gente de lucro e a gente não ganha igual. Acho que é mais diferente (trecho entrevista Edson Guilguer Reimberg, setembro de 2011).

Seu depoimento é bem diferente de outros filhos de agricultores de sua geração. Contudo, sua vocação para atividade agrícola motivou até mesmo a participação de seu pai em capacitações para o manejo orgânico. Também tem grande vontade em permanecer na área onde mora e uma peculiar definição ao ser questionado se morava em um bairro urbano ou rural:

É $80 \%$ interior, mas aqui como é na avenida tem um pouquinho de cidade porque é movimentado. Lá no seu Osvaldo produtor de caqui é rural. Lá um vizinho tem que andar uns 20 km. (trecho entrevista Edson Guilguer Reimberg, setembro de 2011).

Edinho referia-se à propriedade agrícola de seu Osvaldo situada bem no centro da APA Capivari-Monos, em uma localidade com predominância rural. Foi perceptível que a visão de agricultura orgânica de Edinho é bem diferente de seu pai, pois falou com clareza da relação entre agricultura orgânica e preservação ambiental, principalmente, no que tange a necessidade de recuperar a qualidade da água em áreas de mananciais. Também destacou que a chegada do cultivo orgânico na região aconteceu devido ao destaque à questões ambientais que vem acontecendo nos últimos anos: 
O orgânico começou aqui porque tá meio na moda essa coisa de preservação e meio ambiente. Acho que foi meio por isso também. Porque agora tem mais ONG, é mais através disso também. (...) Aqui o mais importante é a água, tem muita nascente, produz muita água aqui, tem duas represas. Água limpa tá até no nome da cooperativa, por isso que é importante também (trecho entrevista Edson Guilguer Reimberg, setembro de 2011).

O jovem agricultor enxerga o manejo orgânico como uma oportunidade de renovação das condições agrícolas na zona sul do município, visto que a desvalorização, a exploração e o abandono está presente constantemente em sua fala.

Acho que é interessante (os cursos) porque que cada dia que passa aqui tá ficando mais difícil a convencional, é muita concorrência e o orgânico acho que é melhor, compensa mais em tudo: qualidade de vida, financeiro, preserva mais o meio ambiente, acho que é mais interessante. (...) Meu pai participou do projeto da 5 Elementos, e eu tô indo na biodinâmica. (...) Entendi a biodinâmica. A gente até brinca que é bruxaria. Temos preparados lá. Ainda não apliquei, agora que tem um pouquinho vou começar a aplicar. (...) O Arpad explicou o agroecológico tem um monte de coisa para chamar assim (trecho entrevista Edson Guilguer Reimberg, setembro de 2011).

A visita foi encerrada com a participação da esposa de seu Benedito que disse acreditar que as novas gerações de agricultores estão mais abertas para realizar o manejo orgânico, pois o agricultor mais antigo aprendeu a cultivar a terra da maneira dele, com venenos e adubos químicos. 


\section{DONA MASSUI SHIRASAWA}

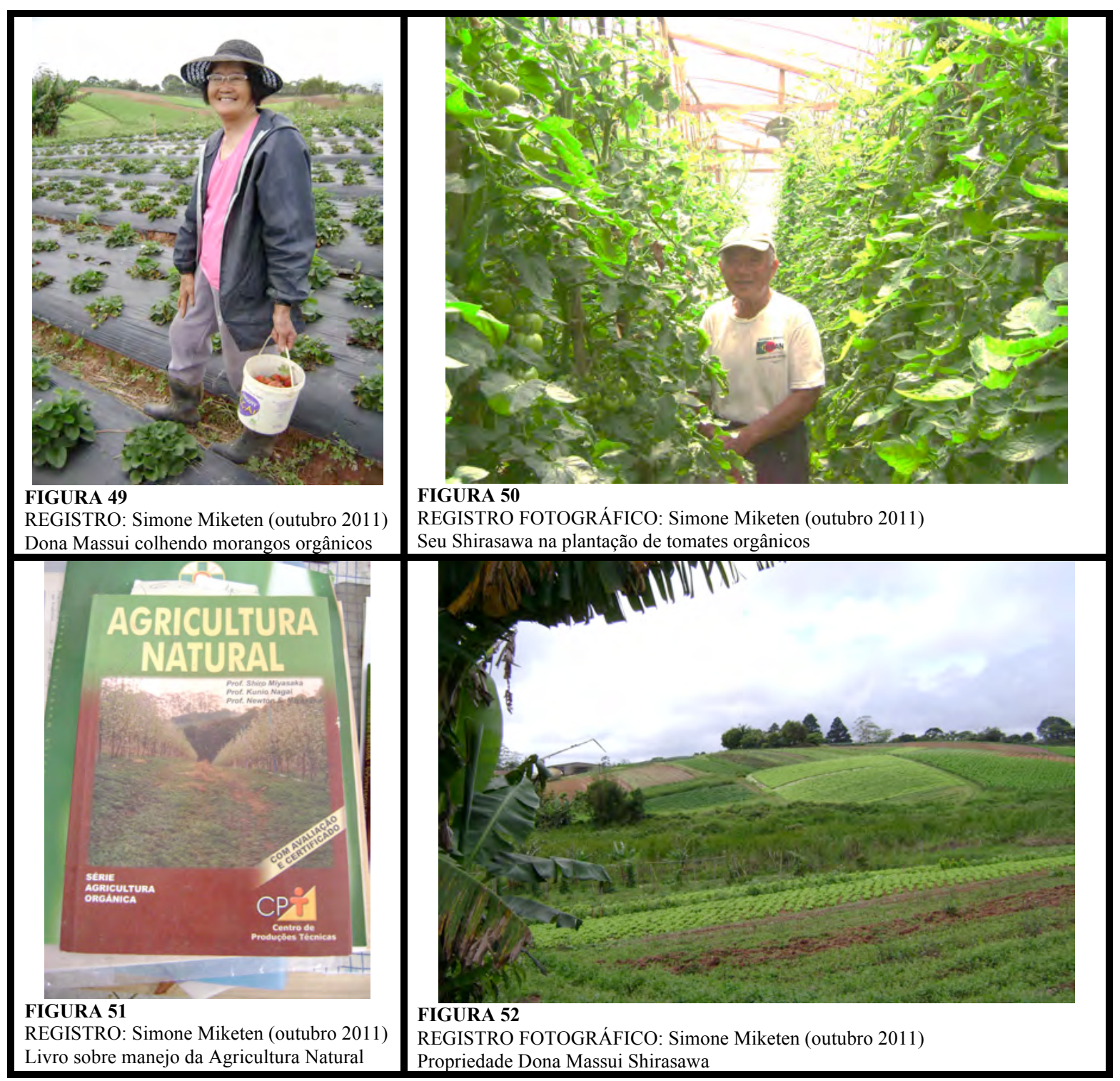

\begin{tabular}{l|l}
\hline ORIGEM & $\begin{array}{l}\text { interior paulista } \\
\text { mora há } 40 \text { anos na área }\end{array}$ \\
\hline TAMANHO PROPRIEDADE & 12 ha \\
\hline MODALIDADE DE USO & proprietária \\
\hline DESTINAÇÃO PRODUÇÃO & varejo local, CEASA, Solo Sagrado \\
\hline TIPO DE MANEJO & parte convencional e parte agricultura orgânica há 3 anos \\
\hline ALGUNS PRODUTOS & acelga, beterraba, brócolis, cebolinha, couve, couve-flor, espinafre; \\
\hline
\end{tabular}




\begin{tabular}{|c|c|}
\hline & orgânicos: tomate, salsão, rúcula, repolho, morango, alface \\
\hline MAQUINÁRIO & $\begin{array}{l}\text { um trator compartilhado entre as cinco unidades de produção } \\
\text { família dos irmãos agricultores }\end{array}$ \\
\hline RENDA AGRÍCOLA & $100 \%$ \\
\hline ENDEREÇO & $\begin{array}{l}\text { Sítio Irmãos Shirasawa } \\
\text { Rua Paulo Guilguer Reimberg, } 8000\end{array}$ \\
\hline ÁREA REFLORESTADA & 1 ha \\
\hline PROJETOS FEMA & Mokiti Okada, ABD, 5 Elementos, Pedro Mataj \\
\hline PROTOCOLO GUARAPIRANGA & $\operatorname{sim}$ \\
\hline COOPERAPAS & $\operatorname{sim}$ \\
\hline CERTIFICAÇÃO & $\overline{\text { não }}$ \\
\hline MANEJO AGROECOLÓGICO & bocachi, composteira, forragem, farelo de arroz \\
\hline OBSERVAÇÕES DE CAMPO & $\begin{array}{l}\text { A agricultura dona Massui é bastante envolvidas nos projetos e } \\
\text { capacitações subsidiadas poder público na região. Contudo, seu } \\
\text { marido e seus cunhados (família Shirasawa) não participam do } \\
\text { processo. Todos os cunhados são convencionais ocasionando a } \\
\text { contaminação dos corpos d'água existentes. Um de seus cunhados } \\
\text { pratica a hidroponia e dona Massui relatou que é o manejo que } \\
\text { mais utiliza veneno nos canteiros da família. }\end{array}$ \\
\hline
\end{tabular}

A segunda visita foi realizada na propriedade da família Shirasawa composta por descendentes dos imigrantes japoneses. Seu Shirasawa e sua esposa dona Massui abriram as portas de uma bela propriedade decorada por técnicas de jardinagem tipicamente japonesas. Inicialmente seu Shirasawa foi relatando como sua família ocupou aquela área enquanto caminhava por estufas e pela produção de tomate. Foi necessário bastante esforço para compreender o acento japonês em sua fala, assim mostrando o quanto a tradição japonesa foi resguardada. Ao ser questionado a respeito do manejo orgânico afirmou:

Não muda nada na hora de trabalhar na terra, só não usa adubo químico. Antes usava algum veneno e agora tem remédio orgânico. Tá dando quase igual orgânico e adubo químico. O serviço é a mesma coisa porque põe adubo a mesma coisa (trecho entrevista seu Shirasawa, outubro de 2011).

Logo dona Massui nos encontrou no canteiro de morangos orgânicos e começou a responder a entrevista de forma bastante prestativa enquanto os colhia. A entrevista foi iniciada com o relato de como a atividade agrícola na região é desvalorizada em relação 
às atividades urbanas que geram maior renda. Dona Massui relata que sua permanência na terra foi subsidiada pelos seus filhos que foram trabalhar no Japão, pois a desvalorização desta atividade na região não gera uma renda suficiente para realizar melhoramentos na produção. A vocação e o amor pela cultura da terra são elementos determinantes para dona Massui ainda desenvolver suas atividades agrícolas.

Hoje o pessoal aqui prefere ser gari do que trabalhar na roça, serviço na cidade. Precisa gostar muito, não troco por nada, nasci e cresci. A agricultura precisa desde quando é pequeno ter amor na terra, aprender trabalhando. Crescer na roça. (...) A agricultura hoje está sendo reconhecida, antes o pessoal tinha vergonha de falar que era agricultor. Isso tá sendo bastante importante para a gente. (...) Como agricultora não consigo nada. Todo os melhoramentos foi porque tive dois filhos que trabalharam no Japão. Para fazer casa e comprar carro. A gente trabalha porque gosta. (...) Pedi PRONAF e ainda não veio resposta (trecho entrevista dona Massui Shirasawa, outubro de 2011).

Dona Massui é uma agricultora bastante envolvida em reuniões e capacitações para o manejo orgânico. Mesmo apresentando bastante interesse, ela afirma que não conhecia o manejo orgânico antes da chegada das ONGs subsidiadas pelos projetos FEMA e os técnicos da Prefeitura, especialmente, os gestores das APAs.

Naquele tempo nunca tinha ouvido falar de orgânico. Ouvi pouco para cá. Aprendi a plantar com adubo químico. (...) Não tinha ouvido falar de orgânico antes, só com o pessoal da USP. Falavam que o produto orgânico é feio, verdura toda furada e assim mesmo o preço é caro. A Incubadora nos incubou e depois desincubou. (...) O orgânico é por causa do APA, Área de Proteção Ambiental. Por causa das nascentes, tem muita água do Billiings vai para Guarapiranga e vai para consumo, para beber. Com orgânico não vai nenhuma química para as águas, porque quando chove a água vai para os rios e contamina tudo. Por causa disso a gente está fazendo a campanha de água limpa. Alguém tem que começar. (...) Antes do pessoal da USP vir nem interessava. Diz que daqui 4 anos não pode usar adubo químico assim, então tô mudando pouco a pouco. Vantagem não tem, o serviço é mesma coisa, alface mesma coisa. Não ficou mais barato (trecho entrevista Massui Shirasawa, outubro de 2011).

Em sua fala é fácil de perceber bastante clareza sobre a importância da conservação ambiental na região e sua relação direta com o manejo orgânico. Contudo, dona Massui deixa explicito que sua abertura para o processo de transição agroecológico 
não parte apenas de sua preocupação com a degradação ambiental, mas é estimulada pelas sanções públicas que estão para chegar na área

Meu cunhado é tudo convencional. Aqui é orgânico sem selo. A gente tem o Protocolo. O selo demora porque tem acompanhamento de dois anos dos técnicos como a Valéria que vai tirar o selo agora pela biodinâmica, junto com mais 8 pessoas. Vamos ver se posso ser incluída, para mim tanto faz Mokiti Okada, biodinâmica, sendo natural, agroecológico. Quem está acompanhando mais o nosso trabalho é a Mokiti Okada com o Leandro. (...) Convertemos para orgânico porque desde 2007 a USP começou a dar esses cursos assim, devido 2014 já precisamos mudar tudo, comecei já a mudar de pouco a pouco porque depressa não dá. Comecei a mudar pela necessidade, pela saúde, pelo meio ambiente. Aqui pertence ao APA então 2014 não vai poder usar nenhuma química. (...) Meu marido não vê muita diferença não. A gente agora tem bastante adubo farelado que nossa! Faz o efeito quase igual a química. Que nem alface assim, pode ver que não tem diferença. Usa bastante bocachi, palhada (trecho entrevista Massui Shirasawa, outubro de 2011).

O casal destacou frequentemente em sua fala a facilidade da conversão do manejo orgânico por conta de técnicas de adubação indicadas pelos técnicos que realizam a assistência técnica. Por enquanto, ambos não perceberam vantagens e nem desvantagem no cultivo orgânico. A entrevista foi finalizada com um delicioso yakisoba de legumes da horta e um suco de morango orgânico. 


\section{VALÉRIA MARIA MACORATTI}

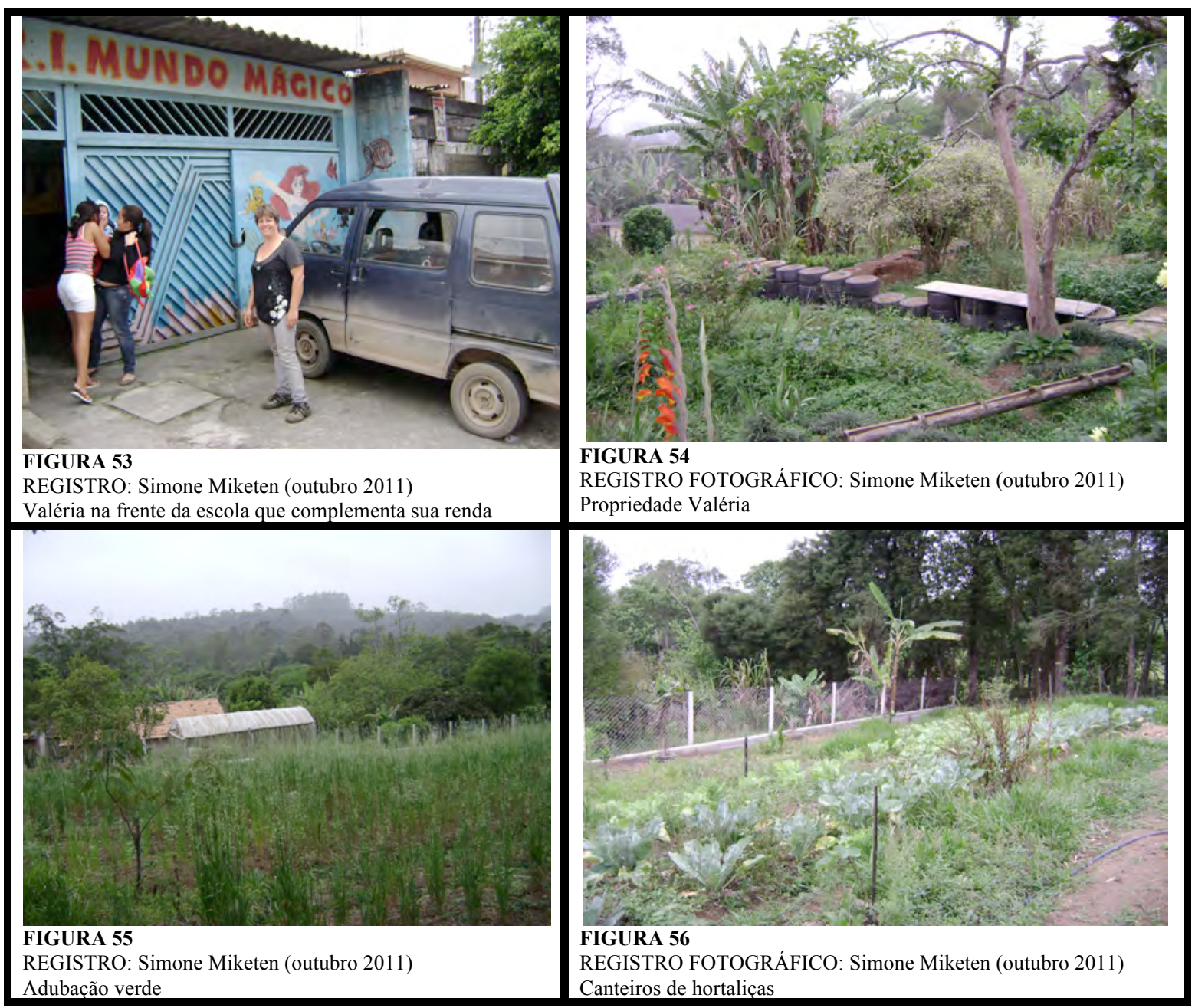

\begin{tabular}{l|l}
\hline ORIGEM & $\begin{array}{l}\text { cidade de São Paulo } \\
\text { reside há 4 anos na área }\end{array}$ \\
\hline TAMANHO PROPRIEDADE & 1 ha \\
\hline MODALIDADE DE USO & proprietária \\
\hline DESTINAÇÃO PRODUÇÃO & $\begin{array}{l}\text { varejo local e feiras do Programa Agricultura Limpa e Protocolo } \\
\text { Guarapiranga }\end{array}$ \\
\hline TIPO DE MANEJO & orgânico \\
\hline ALGUNS PRODUTOS & cebolinha, couve, feijão, limão, pepino \\
\hline MAQUINÁRIO & não \\
\hline RENDA AGRÍCOLA & $30 \%$ \\
\hline ENDEREÇO & Rua sem nome - bairro Chácara Santo Amaro \\
\hline
\end{tabular}




\begin{tabular}{l|l}
\hline ÁREA REFLORESTADA & 1 ha \\
\hline PROJETOS FEMA & ABD e 5 Elementos \\
\hline PROTOCOLO GUARAPIRANGA & sim \\
\hline COOPERAPAS & sim \\
\hline CERTIFICAÇÃO & desistiu \\
\hline MANEJO AGROECOLÓGICO & composteira, esterco, preparados biodinâmicos, adubação verde \\
\hline OBSERVAÇÕES DE CAMPO & $\begin{array}{l}\text { Valéria é uma agricultura recente proveniente do meio urbano. } \\
\text { Desde o início maneja a terra com princípios e práticas } \\
\text { agroecológicas e é bastante engajada nos projetos e capacitações } \\
\text { subsidiadas pelo poder público. Com seu perfil bastante } \\
\text { articulado, disponibilizou sua propriedade como unidade } \\
\text { experimental de alguns projetos, até mesmo para tecnologias de } \\
\text { saneamento ecológico. }\end{array}$ \\
\hline
\end{tabular}

A estadia em sua propriedade foi bastante animada, pois a produtora Valéria foi andando pela produção e detalhando todas as práticas de manejo orgânico que realiza com suas "plantinhas". Sua visão do processo de transição agroecológica é bastante alinhada com os técnicos que realizam a assistência técnica e capacitações agroecológicas, assim mostrando grande clareza acerca do complexo arranjo público criado para esta temática. Além da visita à sua propriedade, ocorreu o acompanhamento à feira do Programa Agricultura Limpa que ocorre semanalmente no parque Burle Marx, onde a produtora Valéria vende sua produção e complementou respostas à sua entrevista.

Aqui é uma feira orgânica livre de agrotóxico junto a Prefeitura. A região de Parelheiros é a última região de São Paulo que ainda resta áreas verdes, áreas preservadas. O rio Capivari é o último rio limpo. Eles fizeram o protocolo. A feira é um ponto da produção que você elimina o atravessador, pois o produtor vem vender a preços baixos e totalmente legalizada. Os projetos FEMA são projetos da Prefeitura. O Protocolo de Boas Práticas Agroambientais, o Protocolo Guarapiranga foi instituído pela Prefeitura de São Paulo com o selo Guarapiranga, que quer dizer garça vermelha e é o nome da represa. Aqui tem a garantia da Prefeitura e nós estamos tendo acompanhamento técnico com o pessoal da Casa da Agricultura. Tem procedência, pois o produtor tá preocupado e produz água. $30 \mathrm{a}$ $40 \%$ da água produzida em São Paulo é em Parelheiros. Então se não preservarmos essa região não vai ter água. E é junto a Prefeitura, junto com o governo do Estado que fizeram esse Protocolo Guarapiranga (trecho entrevista Valéria Macoratti, abril de 2012) 
A observação da comercialização na feira trouxe uma importante perspectiva para a pesquisa, pois foi possível averiguar todo o processo na cadeia produtiva. Esta iniciativa municipal de implementar feiras para produtores com certificação orgânica e agricultores em transição acompanhados pelo Protocolo Guarapiranga, trouxe um grande avanço à transição agroecológica, pois abriu oportunidades ao produtor de realizar a venda de sua produção e perceber a viabilidade da produção orgânica.

As pessoas ficam fascinadas de ver uma coisa totalmente diferente, com muito menos emissão de carbono para vir vender porque está perto. E você produtor que vem vender pode deixar sua propriedade aberta para visitação. Qualquer cliente aqui nosso que quiser ir na nossa propriedade, como já foram, nós estamos de portas abertas, mostrando o que a gente faz, então tem essa transparência. (...) Você sabe o que está comprando, está consumindo saúde e está preservando a água da nossa cidade também. Muitos já instituíram um vínculo de amizade com a gente que podem estar ligando, podem estar encomendando (trecho entrevista Valéria Macoratti, abril de 2012).

Outro aspecto importante levantado pela produtora foram os benefícios da relação direta entre produtor e consumidor, pois o fato do consumidor ter uma estreita relação com o produtor amplia a visão específica baseada no consumo de produtos para a valorização do território onde acontece todo um processo produtivo. Com efeito, alguns resultado positivos podem ser elencados como o fortalecimento da identidade do território e a valorização da multifuncionalidade da agricultura enquanto produtor de alimentos de qualidade e prestador de serviços ambientais. 


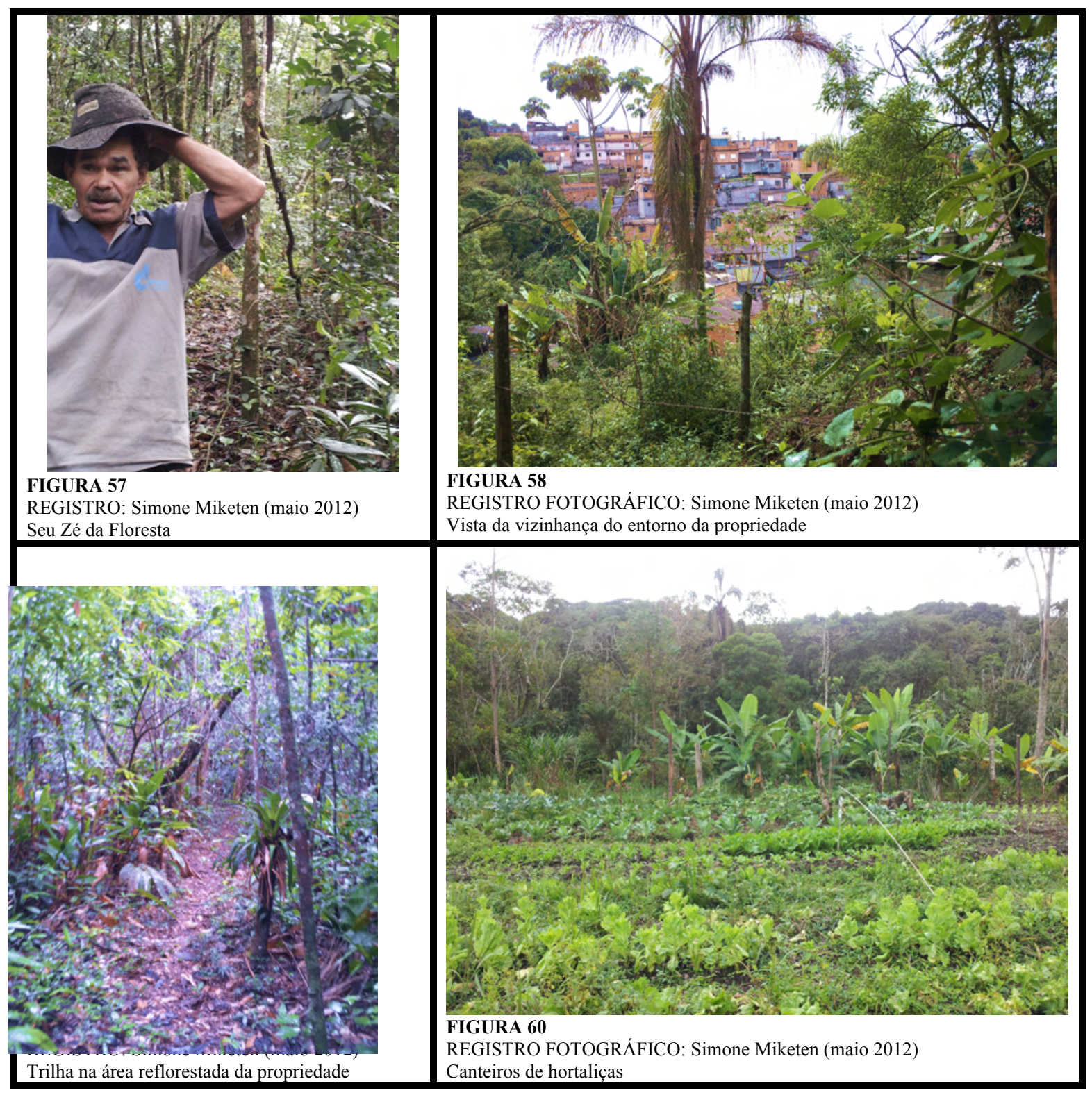

\begin{tabular}{l|l}
\hline ORIGEM & $\begin{array}{l}\text { Nordeste } \\
\text { mora há } 28 \text { anos na área }\end{array}$ \\
\hline TAMANHO PROPRIEDADE & 2 ha \\
\hline MODALIDADE DE USO & posseiro \\
\hline DESTINAÇÃO PRODUÇ̃̃O & feiras do Programa Agricultura Limpa e Protocolo Guarapiranga \\
\hline TIPO DE MANEJO & orgânico e sistema agroflorestal \\
\hline
\end{tabular}




\begin{tabular}{l|l}
\hline & \\
\hline ALGUNS PRODUTOS & alface, couve, cenoura, milho, cambuci, banana \\
\hline MAQUINÁRIO & não \\
\hline RENDA AGRÍCOLA & não declarada \\
\hline ENDEREÇO & não declarado \\
\hline ÁREA REFLORESTADA & 1 ha \\
\hline PROJETOS FEMA & Mokiti Okada, 5 Elementos, ABD, Pedro Mataj \\
\hline PROTOCOLO GUARAPIRANGA & sim \\
\hline COOPERAPAS & sim \\
\hline CERTIFICAÇÃO & sim \\
\hline MANEJO AGROECOLÓGICO & composteira, esterco, preparados biodinâmicos, adubação verde \\
\hline OBSERVAÇÕES DE CAMPO & $\begin{array}{l}\text { Seu Zé da Floresta iniciou suas práticas de cultivo realizando o } \\
\text { reflorestamento de sua área com espécies nativas. Plantou } \\
\text { frutíferas e algumas hortaliças. Depois dos projetos subsidiados } \\
\text { pelo FEMA, iniciou sua produção com canteiros de hortaliças. Sua } \\
\text { propriedade tornou-se conhecida por conta de sua agrofloresta } \\
\text { cultivada de forma intuitiva. }\end{array}$ \\
\hline
\end{tabular}

Seu Zé da Floresta é um agricultor bastante peculiar na área pelo fato de sozinho ter cultivado mais de 1 ha de espécies nativas objetivando a preservação ecológica de sua propriedade. Isso foi possibilitado porque era remunerado por seu trabalho na indústria. Hoje aposentado, há pouco tempo organizou uma horta e vive de fato da comercialização de sua produção. Anteriormente plantava alguns gêneros alimentícios em meio a espécies arbóreas, mas o investimento era mais voltado para o reflorestamento do que para a produção.

Eu tenho pouco mesmo porque o meu era só agroflorestal, agora que tô começando a prantá verdura. Veio os meninos e aqui é agroflorestal e eu nunca tinha ouvido falar esse nome (trecho entrevista Zé da Floresta, maio de 2012).

Sua casa é bastante modesta em relação à exuberância natural de seu sítio e não possui maquinário para a produção, nem mesmo automóvel para transportar os produtos. Com grande simpatia e disposição, em grande parte do tempo da visita contou todo processo que passou junto à Prefeitura para conseguir ocupar sua área sem ser retirado 
desta. O pouco que falou sobre o manejo orgânico, foi enquanto caminhava pela trilha que demarcou com o intuito de levar os visitantes a conhecer a mata que se dedica há vinte e oito anos. Em seu entendimento, orgânico significa cultivar a produção sem a utilização de venenos e adubos sintéticos. Contudo, relata que a chegada dos técnicos para auxiliar na produção orgânica trouxe uma série de regulamentações burocráticas por conta das normas ambientais que incidem na área.

Eu entendi o orgânico menos burocrático do que é hoje. Antes orgânico era pranto e não colocou nada de química, agora tem o burocrático. Hoje tem o meio ambiente junto, eu achava que não tinha que ser as coisas junto (trecho entrevista Zé da Floresta, maio de 2012).

É bastante interessante perceber que o relato de uma pessoa naturalmente preservacionista mostra uma série de queixas quanto aos procedimentos burocráticos de técnicos que regulamentam as normas de conservação ambiental. Entretanto, seu Zé da Floresta elogiou bastante a assistência destes técnicos que possibilitou concretizar o manejo orgânico de sua produção com fins de comercialização. A visita foi finalizada com a surpresa de um farto almoço preparado por sua esposa. 


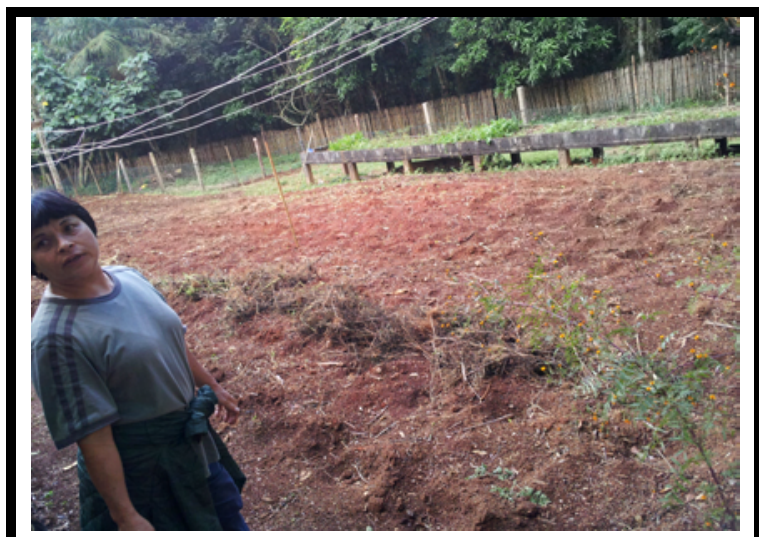

FIGURA 61

REGISTRO FOTOGRÁFICO: Simone Miketen (maio 2012) Tomico em sua área de plantio

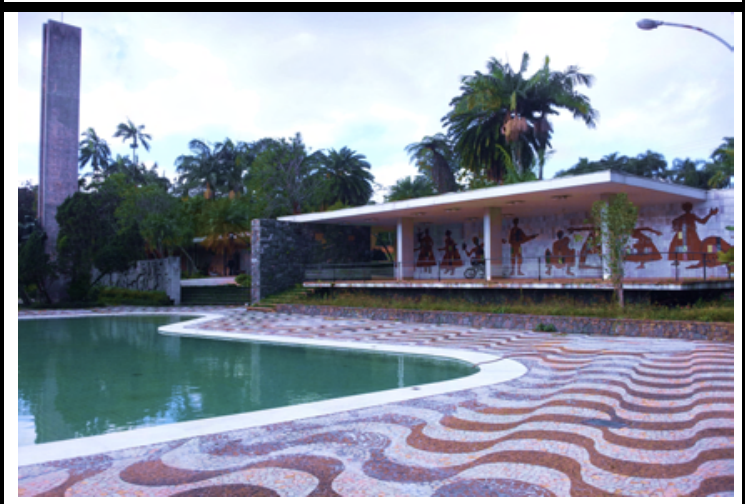

FIGURA 63

REGISTRO FOTOGRÁFICO: Simone Miketen (maio 2012) Propriedade Tomico

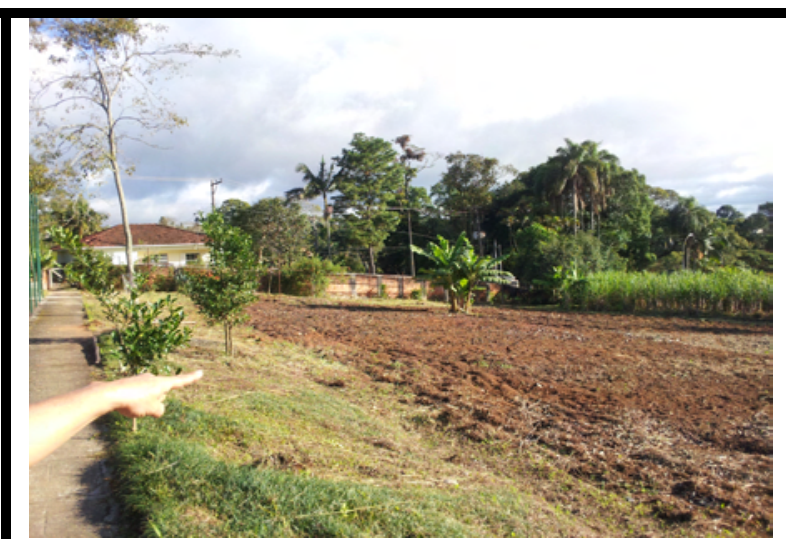

FIGURA 62

REGISTRO FOTOGRÁFICO: Simone Miketen (maio 2012) Outra área de plantio com cana-de-açúcar

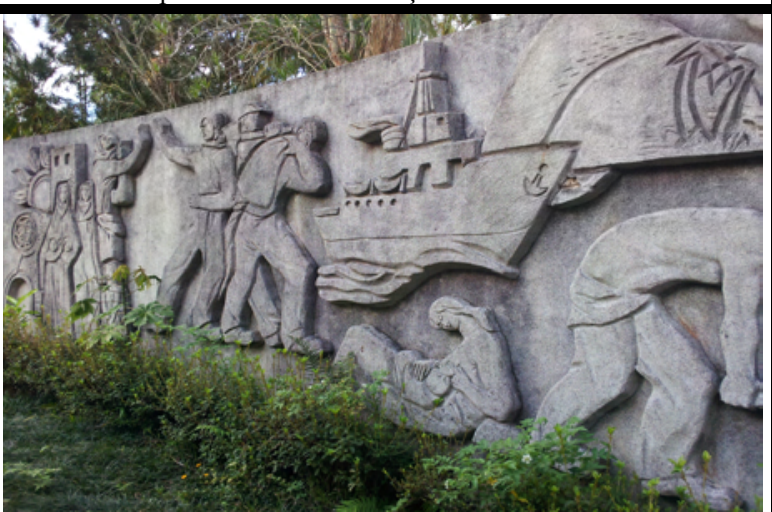

FIGURA 64

REGISTRO FOTOGRÁFICO: Simone Miketen (maio 2012)

Painel esculpido com a vida do pai de Tomico

\begin{tabular}{l|l}
\hline ORIGEM & cidade de São Paulo \\
\hline TAMANHO PROPRIEDADE & 2,2 ha \\
\hline MODALIDADE DE USO & proprietária \\
\hline DESTINAÇÃO PRODUÇ̃̃O & feiras Programa Agricultura Limpa e Protocolo Guarapiranga \\
\hline TIPO DE MANEJO & orgânico \\
\hline ALGUNS PRODUTOS & batata, cana-de-açúcar, mexerica, carambola, alface, couve \\
\hline MAQUINÁRIO & 1 tobata \\
\hline RENDA AGRÍCOLA & $20 \%$ \\
\hline ENDEREÇO & $\begin{array}{l}\text { Sítio Piquerê } \\
\text { Rua São Genésio, } 55\end{array}$ \\
\hline
\end{tabular}




\begin{tabular}{l|l}
\hline ÁREA REFLORESTADA & não declarada \\
\hline PROJETOS FEMA & ABD \\
\hline PROTOCOLO GUARAPIRANGA & sim \\
\hline COOPERAPAS & sim \\
\hline CERTIFICAÇÃO & orgânica \\
\hline MANEJO AGROECOLÓGICO & composteira, esterco, preparados biodinâmicos, adubação verde \\
\hline FEIRAS & Água Branca e Biodinâmica \\
\hline OBSERVAÇÕES DE CAMPO & $\begin{array}{l}\text { Tomico é uma agricultora recente bastante envolvida com os } \\
\text { projetos e capacitações subsidiadas pelo poder público. Possui } \\
\text { uma propriedade que sempre recebeu visitas de fins de semana } \\
\text { porque tem áreas com obras de artes modernistas. Possui } \\
\text { empregados para ajudar no cultivo. }\end{array}$ \\
\hline
\end{tabular}

A agricultora Maria José, que é conhecida como Tomico ou apenas Tomi, tem o perfil completamente diferente dos outros produtores. Sua produção está localizada em um grande sítio herdado da família que assemelha-se a um museu modernista. Seu pai utilizava a propriedade como fonte de renda promovendo atividades de uma chácara de lazer. Tomi contou que seu pai contratou um artista discípulo do paisagista Burle Marx para decorar o sítio. Nas ilustrações fotográficas acima é possível enxergar uma pequena demonstração da propriedade repleta de obras de arte. Grande parte da entrevista foi dedicada ao depoimento do histórico de ocupação da propriedade que passou por diversas modalidades de uso. Tomi relatou que viveu a maior parte de sua vida no centro da cidade de São Paulo. Quando adquiriu o sítio, realizava o aluguel da propriedade principalmente para escolas proporcionando atividades de cultura, horta com fins de educação ambiental e até mesmo oficinas de panificação.

O cultivo da produção para comercialização foi recente. Sua vocação para agricultura foi concretizada a partir do momento que entrou em contato com os técnicos dos projetos fomentados pelo FEMA e, principalmente, pelo convívio com outros agricultores proporcionado por estes cursos. Anteriormente, chegou a acompanhar a produção de seu avô quando era vivo, mas suas atividades sempre foram urbanas. Ao ser perguntada sobre o manejo orgânico, Tomi mostrou-se cativada com o uso dos preparados biodinâmicos em sua produção. 
Meu avô usava esterco orgânico. Eu não sabia o que era orgânico. Só depois do curso batizei a horta e a hora que batiza é uma evolução, o negócio veio assim. O milho cresceu muito só com matéria-orgânica da área, sem adubação (trecho entrevista Maria José Kunikawa, maio de 2012).

Ao usar a palavra batizar, Tomi está referindo-se ao momento que esparge o preparado biodinâmico nas plantas e no solo. Outro ponto relevante da entrevista foi a constatação que o alimento mais próximo do consumidor, que realiza um menor percurso, chega mais fresco aos locais de venda. Isto mostra a grande importância da valorização dos produtores que têm suas lavouras localizadas nas proximidades da cidade.

O Zunde fala que minha mercadoria tá muito boa para ser orgânica. Acho que é porque eu tô indo para feira amanhã e eu tô colhendo hoje. O pessoal vem de Minas e colheram há 3 ou 4 dias. Aqui de São Paulo fica mais fresquinho e a fruta fica mais bonito, tem um brilho (trecho entrevista Maria José Kunikawa, maio de 2012).

\subsection{ENCONTROS REGIONAIS DE AGRICULTURA}

O outro foco de análise incorporado à pesquisa foi o subgrupo (2) de produtores(as) agrícolas não contemplados por projetos e ações do poder público frente ao processo de transição agroecológica. O levantamento de dados foi realizado com procedimentos metodológicos qualitativos baseados em grupos focais, pois a presente pesquisadora teve a oportunidade de participar e levantar dados de reuniões estratégicas realizadas nas APAs Capivari-Monos e Bororé-Colônia com produtores agrícolas locais. Como consequência, a área de estudos foi expandida para a APA Capivari-Monos porque, neste caso, as realidades são bastante similares, sendo que os arranjos territoriais não respeitam limites administrativos.

Estes chamados Encontros Regionais foram reuniões prévias para divulgação e levantamento das necessidades da agricultura em cada bairro, os quais objetivaram subsidiar o terceiro Encontro de Planejamento Estratégico em Agricultura promovido pela Câmara Técnica conjunta de Agricultura e Desenvolvimento Rural Sustentável das APAs Capivari-Monos e Bororé-Colônia, juntamente com agricultores; com técnicos do órgão municipal ABAST; com técnicos dos órgãos estaduais CATI (Centro Assistência Técnica integral), SMA (Secretaria Estadual do Meio Ambiente), IEA (Instituto de 
Economia Agrícola), IBT (Instituto de Botânica), e com as ONGs 5 Elementos e Instituto Kairos. Este encontro maior aconteceu no dia 12/12/12 e contou com a ilustre presença da engenheira agrônoma Ana Primavesi, a qual é referência mundial em pesquisas acerca do manejo orgânico do solo.

Os Encontros Regionais ocorreram com o objetivo de:

(1) Promover encontros em locais mais próximos às propriedades dos agricultores para reunir o maior número possível de participantes, principalmente, produtores não envolvidos no processo de transição agroecológica.

(2) Sensibilizar agricultores não envolvidos no processo de transição agroecológica por meio de demonstração de métodos de baixo impacto.

(3) Realizar pré-diagnóstico para o Encontro de Planejamento Estratégico em Agricultura por meio do levantamento de necessidades dos agricultores e identificação de problemas locais.

Todas as reuniões ocorreram no mês de outubro e contaram com a participação de uma equipe de técnicos reunidos com agricultores dos mais diversos perfis (orgânicos, em transição e convencionais; familiares e patronais; ornamentais e oleicultores; proprietários e funcionários; jovens e adultos). As perguntas que nortearam todos os Encontros Regionais foram: (1) quais os pontos fortes da agricultura no bairro e (2) quais as dificuldades da agricultura no bairro. As respostas foram anotadas em flipchart, havendo também um técnico relator que anotava a dinâmica da reunião.

O primeiro encontro foi realizado no bairro Chácara Santo Amaro localizado na APA Bororé-Colônia. A Agricultora Valéria divulgou entre os produtores locais e cedeu sua propriedade para a realização do evento. Compareceram funcionários e pequenos produtores de oleicultura em sua maioria convencionais. Foi relatado o caso de uma das funcionárias presentes que perdeu seu marido por conta de intoxicação por agrotóxico.

O segundo encontro ocorreu no bairro de Cratera de Colônia na propriedade do seu Tsuka e da Dona Diná. A maioria dos presentes eram japoneses e descendentes com o sotaque bem cadenciado. Os participantes cultivavam ornamentais e hortaliças majoritariamente convencionais. Ocorreu outro encontro na Cratera de Colônia na semana seguinte, pois havia uma separação entre os agricultores remanescentes de 
alemães e de japoneses. Este terceiro encontro teve uma característica diferenciada porque a maioria dos participantes eram jovens funcionários que trabalhavam para agricultores convencionais e patronais. Por este motivo, a reunião foi diferente da usual, inclusive porque aconteceu em um bar local.

No bairro de Embura ocorreu o quarto encontro no Instituto Pedro Mataj, o qual foi proponente de projetos de capacitação orgânica subsidiados pelo FEMA. Participaram produtores orgânicos e produtores convencionais. O último Encontro Regional aconteceu no bairro de Barragem tendo um perfil de agricultores(as) completamente diferente dos demais, pois a maioria eram grandes produtores convencionais de ornamentais. Houve também um encontro no bairro do Jaceguava, o qual não está localizado nas APAs. Porém, os dados não foram levantados e contabilizados. Abaixo seguem as tabelas com os pontos fortes e as dificuldades encontradas para o estabelecimento da agricultura nas respectivas localidades:

\begin{tabular}{|c|c|}
\hline BAIRRO & PONTOS FORTES \\
\hline Chácara Santo Amaro & $\begin{array}{ll}\text { - } & \text { Esterco de galinha } \\
\text { - } & \text { Esterco de gado }\end{array}$ \\
\hline Cratera de Colônia I & $\begin{array}{l}\text { - Área preservada (ar puro, aves, natureza, saúde) } \\
\text { - }\end{array}$ \\
\hline Cratera de Colônia II & $\begin{array}{l}\text { - Natureza: ar de qualidade, água, solo, rio para pescar } \\
\text { - } \quad \text { Expansão da agricultura } \\
\text { Proximidade casa-trabalho }\end{array}$ \\
\hline Embura & $\begin{array}{ll}\text { - } & \text { Ar - Recursos hídricos } \\
\text { - } & \text { Produção orgânica } \\
\text { - } & \text { Projetos FEMA } \\
& \text { Vontade de produzir }\end{array}$ \\
\hline Barragem & $\begin{array}{ll}\text { - } & \text { Natureza - Água - Clima } \\
\text { - } & \text { Grande quantidade de produtores na região } \\
\text { - } & \text { Identidade com a região } \\
\text { - } & \text { Proximidade CEASA } \\
\end{array}$ \\
\hline
\end{tabular}

BAIRRO

Chácara Santo Amaro

\section{DIFICULDADES}

- Reconhecimento da agricultura na região

- Desvalorização do agricultor

- Violência

- Falta de transporte e má qualidade

- Burocracia - Legislação - Documentação

- Dificuldade financiamento

- Falsas expectativas geradas

- Falta de mão-de-obra 


\begin{tabular}{|c|c|}
\hline & $\begin{array}{ll}\text { - } & \text { Falta de orientação técnica agroecológica } \\
\text { - } & \text { Contaminação por agrotóxico } \\
\text { - } & \text { Combate às plantas espontâneas } \\
\text { - } & \text { Combate ao pulgão } \\
\text { - } & \text { Mudança nos padrões de comportamento }\end{array}$ \\
\hline Cratera de Colônia I & $\begin{array}{ll}\text { - } & \text { Burocracia } \\
\text { - } & \text { Falta assistência técnica especializada para setores específicos } \\
\text { - } & \text { Burocracia para ter acesso à DAP } \\
\text { - } & \text { Acesso ao mercado } \\
\text { - } & \text { Planejamento da produção } \\
\text { - } & \text { Não tem compradores para ornamentais } \\
\text { - } & \text { Falta mão-de-obra qualificada } \\
\text { - } & \text { Agricultores são individualistas } \\
\text { - } & \text { Alto custo dos insumos orgânicos } \\
\text { - } & \text { Alto custo da produção } \\
\text { - } & \text { Restrição circulação de caminhão na cidade } \\
\text { - } & \text { Falta agregar valor ao produto } \\
\text { - } & \text { Falta apoio à cooperativa } \\
\text { - } & \text { Falta de acesso aos meios de certificação } \\
\text { - } & \text { Falta de plano de manejo }\end{array}$ \\
\hline Cratera de Colônia II & $\begin{array}{l}\text { - } \quad \text { Deficiência nos meios de comunicação - internet e telefonia } \\
\text { - } \quad \text { Manutenção das vias de transporte } \\
\text { Criminalidade }\end{array}$ \\
\hline Embura & $\begin{array}{ll}\text { - } & \text { Desvalorização do agricultor } \\
\text { - } & \text { Burocracia e falta de informação } \\
\text { - } & \text { Ponto de reciclagem } \\
\text { - } & \text { Assistência técnica e extensão rural } \\
\text { - } & \text { Certificação orgânica } \\
\text { - } & \text { Continuidade dos projetos } \\
\text { - } & \text { Sucessão na agricultura } \\
\text { - } & \text { Planejamento da produção } \\
\text { - } & \text { Outorga da água } \\
\text { - } & \text { Poluição da água }\end{array}$ \\
\hline Barragem & $\begin{array}{ll}\text { - } & \text { Reconhecimento da agricultura na região } \\
\text { - } & \text { Fesvalorização do agricultor } \\
\text { - } & \text { Contaminação da água por agrotóxicos } \\
\text { - } & \text { Roubo de mudas de ornamentais } \\
\text { - } & \text { vias mal conservadas para transporte de produtos } \\
\text { - } & \text { Falta de energia elétrica } \\
\text { - } & \text { Financiamento } \\
\text { - } & \text { Falta de assistência técnica e informação } \\
\text { - } & \text { Resistência às mudanças } \\
\text { - } & \text { Falta Informações sobre as produções locais } \\
\text { - } & \text { Falta de mão-de-obra } \\
\text { - } & \text { Sucessão da agricultura } \\
\text { - } & \text { Comercialização - atravessador e consumidor direto } \\
\text { - } & \text { Outorga da água } \\
\text { - } & \text { Dificuldade em obter esterco de qualidade }\end{array}$ \\
\hline
\end{tabular}


De forma conclusiva, o primeiro elemento que foi possível observar é a maior facilidade que os agricultores têm em apontar as dificuldades em relação aos pontos fortes das atividades agrícolas em seus bairros. A maioria relatou que a falta de valorização e reconhecimento da atividade agrícola no município gera uma série de consequências que podiam ser evitadas. Houveram vários depoimentos apontando que as ações da Prefeitura na região não são pautadas em apoio à agricultura, pois quando raramente aparecem nos bairros trazem uma gama de dificuldades burocráticas e penalidades por se tratar de uma área preservada.

Ao serem questionados acerca da transição para a produção orgânica, muitos dizem que não existe informação, assitência técnica de qualidade e permanente, fornecimento de insumos, principalmente esterco de qualidade, e tampouco apoio à comercialização ou mesmo crédito agrícola. Quase que a totalidade deles afirmaram que não são contra o processo de transição, porém sem subsídios concretos do poder público os produtores acreditam que será impossível estabelecer o manejo orgânico para a maioria das propriedades.

Algumas características da área também foram apontadas como barreiras à produção agrícola como a falta de regularização fundiária, a inexistência de mão-de-obra para auxiliar no cultivo, a poluição e a falta de incentivos para a produção de alimentos. Muitos relataram que vem ocorrendo uma migração da produção de hortaliças para ornamentais por conta da falta de assistência técnica para a produção de alimentos de qualidade. Outra grande preocupação é o desestímulo da permanência do jovem no campo porque não existe um curso técnico agrícola que incentive a permanência da próxima geração na região. 


\section{CONSIDERAÇÕES FINAIS}

Diante a interpretação de evidências empíricas e vivências em campo na área de estudos, torna-se possível concluir que a hipótese contribuiu de forma adequada às interpretações e considerações finais da presente investigação científica. Isto porque as atividades agrícolas na porção sul do município de São Paulo, orientadas no sentido da transição agroecológica, cada vez mais ganham visibilidade e vêm sendo valorizadas na agenda das políticas públicas enquanto estratégia para conservação ambiental e contensão da expansão urbana nas áreas de mananciais, especialmente, pelo fato de ocupar áreas de forma a preservar a qualidade ambiental e proteger a paisagem natural. Este processo vem sendo fortalecido porque o alto impacto da urbanização resultou em uma série de consequências ambientais que causam riscos ao provimento de recursos hídricos e naturais para áreas centrais do município.

Neste sentido, foi averiguado a partir dos dados coletados em campo que os agricultores beneficiado pelas diversas ações do poder público, frente ao processo de transição agroecológica, estão confiantes a respeito da novidade do manejo de baixo impacto de acordo com os seguintes motivos elencados por prioridade: (1) a assistência técnica pública e o apoio à comercialização e à adequação ambiental das propriedades estão ocorrendo no município especificamente objetivando a transição para produção orgânica; (2) estrategicamente o produto orgânico tem maior valor financeiro para comercialização frente a concorrência com grandes produtores convencionais; (3) os agricultores em geral estão alarmados com futuras sanções públicas das legilações ambientais que incidem na área de mananciais; (4) além da proatividade dos agricultores em relação a conservação de recursos naturais para a continuidade da prática agrícola no ambiente. Os produtores que não receberam o apoio advindo do poder público apresentam uma forte resistência à transição agroecológica, mas, em parte, estão abertos a esclarecimentos acerca do manejo orgânico e da adequação ambiental necesária para continuidade de suas atividades agrícolas.

Com efeito, este processo precisa ser fortalecido por instrumentos de regulação e adequações ambientais com prazos definidos, assim consolidando ações respaudadas em políticas públicas para além da boa vontade de técnicos e produtores. Entretanto, é 
necessário ter clareza e direcionar as ações no sentido das necessidades concretas dos agricultores locais, pois a transição agroecológica apenas poderá ser consolidada se diversos elementos da própria atividade agrícola estiverem estabelecidos, tais como: o suprimento de insumos orgânicos de qualidade; o apoio público à adequação ambiental das propriedades como plano de manejo, a averbação de Reserva Legal, a recuperação de áreas de preservação permanente (APP); a organização efetiva e continuada de assitência técnica e apoio à comercialização; o fomento à políticas públicas que integrem a esfera ambiental à agricultura; os subsídios aos programas de compras públicas; e, especialmente, a solução do problema fundiário, pois grande parte dos produtores não têm nem mesmo a posse de sua terra, acarretando na maior barreira para a concreta execução da maioria benefícios nas esferas estaduais e federais.

Outro aspecto importante, encontrado como elemento surpresa, foi a falta de protagonismo dos agricultores em relação ao próprio processo de transição agroecológica, pois a totalidade de técnicos e agricultores entrevistados afirmaram que não existe um histórico consolidado de práticas e comercialização de produtos manejados de acordo com critérios da agricultura orgânica, mas sim apenas algumas ações pulverizadas que não foram consolidades de forma organizada.

Isto demonstra a grande relevância da rede de iniciativas do Poder Executivo Municipal para consolidação da atividade agrícola através de estratégias intersecretariais como o PROAURP; a criação das Casas de Agricultura Ecológica para realizar assisitência técnica e apoio à comercialização; os subsídios advindos da SVMA por meio do FEMA e da Câmara Técnica conjunta de Agricultura e Desenvolvimento Rural Sustentável dos Conselhos Gestores das APAs Capivari-Monos e Bororé-Colônia que possibilitaram a certificação orgânica na região; as feiras efetivadas pela ABAST, através do Programa Agricultura Limpa, que acontecem semanalmente nos parques Burle Marx, Ibirapuera e Água Branca; o apoio à criação da cooperativa CoopeApas; o Protocolo Guarapiranga firmado com a esfera estadual para o acompanhamento do plano de conversão para adequação ambiental.

O Poder Legislativo Municipal recentemente formalizou seu apoio à agroecologia e produção orgânica, principalmente, por meio da assinatura da Plataforma de Apoio à Agricultura Orgânica no município de São Paulo conjuntamente com mais de treze 
instituições da sociedade civil, a qual aponta para importantes reinvidicações para fortalecer a produção agrícola livre de venenos e adubos sintéticos que foram debatidas na primeira Semana de Agroecologia ocorrida na Câmara Municipal no mês de maio de 2013. Este rico debate contou com a participação de representantes dos Poderes municipal, Estaduais e Federal. No âmbito estadual, foi lançada a Frente Parlmentar de Agricultura Orgânica na Assembleia Legislativa do Estado de São Paulo, em maio de 2013, conjuntamente com mais de cinquenta entidades da sociedade civil e aproximados trinta parlamentares. Todos reunidos com o objetivo de apoiar e promover ações para consolidação de políticas públicas voltadas para agroecologia e produção orgânica.

A presença da sociedade civil torna-se cada vez mais expressiva, especialmente, nas reinvindicações acerca do estabelecimento de atividades agrícolas no espaço intraurbano. Como exemplo, existe a rede de agricultores urbanos chamada Hortelões Urbanos que, sediada no espaço das redes virtuais, cria por conta própria hortas em áreas centrais da cidade, para fins de ocupação do espaço, como a Horta do Ciclista cultivada em plena avenida Paulista.

Um dos efeitos de maior visibilidade em todo o processo é o crescimento exponencial da relevância do tema agricultura, no espaço intraurbano e arrabaldes da cidade, que emerge na consolidação da abertura do diálogo entre setores públicos e a sociedade civil, além do significante destaque na mídia, especialmente, pelo seu potencial para a conservação ambiental. A grande rede, descrita no segundo capítulo, que vem sendo tecida entre os Poderes Executivos e Legislativos Municipais, as instâncias Estadual e Federal e a sociedade civil aponta para diversos rumos promissores para a agricultura paulistana.

Contudo, a integração de temas e condicionantes que emergem da atividade agrícola situada nas localizações urbanas e periurbanas contribuem para a revisão e o aprofundamento de definições acadêmicas e normatizações públicas acerca da própria agricultura. A demasiada falta de clareza e o intenso debate em andamento levantam questões fundamentais demasiadamente complexas que exigem grandes transformações em entendimentos de categorias-chave como a noção de cidade e sua relação com espaços agrícolas; o estabelecimento de localizações urbanas e rurais; o potencial de conservação ambiental da atividade agrícola voltada para princípios e prática da 
agroecologia, assim fortalecendo aspectos da multifuncionalidade da agricultura; a valorização de agricultores situados em espaços periurbanos que além do abastecimento de alimentos de qualidade, podem ser prestadores de serviços públicos; e o importante processo de transição agroecológica para fortalecimento de um modelo ambientalmente equilibrado de cultivo agrícola.

No momento atual, a capital paulistana apresenta um importante arranjo público de fomento à transição agroecológica em nível municipal. Porém, os esforços nesse sentido necessitam, em caráter de urgência, de parcerias mais concretas com as esferas estadual e federal por uma série de argumentos evidenciados pelo presente processo de investigação científica. Primeiramente, a constante associação entre rural (localização) e agricultura (atividade econômica) distanciou o poder municipal das atribuições condizentes com esta atividade, por este motivo, importantes instrumentos normativos e processos de tomada de decisão residem nas instâncias estadual e federal. Outro ponto importante é a dimensão da cidade que extrapola o limite municipal para a escala metropolitana, visto que possui elementos que transbordam para além de seu perímetro, à exemplo da gigantesca mancha urbana consolidada.

Contudo, a grande questão que emerge, acerca da agricultura e da conservação ambiental, consiste na recriação, ou não, da zona rural no extremo sul do município de São Paulo. Por um lado, os moradores destas áreas aguardam melhorias na infraestrutura urbana e, por outro, o estabelecimento do perímetro urbano traz riscos para a preservação de seus maciços florestais e da própria atividade agrícola. De qualquer forma, a decisão que deverá ser tomada depende do aprofundamento em questões como (1) a regularização fundiária é o elemento central para garantir que os agricultores locais obtenham benefícios públicos nos âmbitos estadual e federal e normatizem sua atividade, porém, sua efetivação em perímetro urbano pode significar a valorização da terra e consequente venda dos terrenos para outros fins que não sejam à prática agrícola; (2) o estabelecimento de uma zona rural deve prever um zoneamento estratégico para garantir a qualidade dos núcleos urbanizados; (3) será necessário consolidar um detalhado levantamento da produção agrícola a fim de reconhecer o perfil da pluriatividade do agricultor local, visto que o fácil acesso às atividades urbanas podem dificultar o enquadramento dos produtores no perfil exigido pela legislação acerca da agricultura 
familiar; (4) a atividade agrícola deve ser valorizada não apenas enquanto produto, mas também como prestação de serviços ambientais, ecológicos e culturais de acordo com sua multifuncionalidade; (5) é necessário aprofundar o debate a respeito das estratégias que podem ser concretizadas pela definição de espaços periurbanos, os quais apresentam características para além da dicotomia urbano e rural.

É necessário não perder de vista que a proteção das áreas de mananciais necessita de um processo de transição agroecológica, visto que a quantidade de venenos e adubos sintéticos tende a aumentar exponencialmente por conta da degradação do solo. Contudo, a consolidação deste processo depende da participação direta dos agricultores, os quais precisam constantemente de acompanhamento técnico e apoio para manter a própria sobrevivência. Neste sentido, a agroecologia deve ser tratada como um horizonte a ser alcançado por meio do fortalecimento dos elementos vitais para a tenacidade da agricultura familiar nos arrabaldes da cidade. 


\section{REFERÊNCIAS BIBLIOGRÁFICAS}

5 ELEMENTOS - Instituto de Educação e Pesquisa Ambiental. Educação Ambiental para a agricultura orgânica nas APAs Bororé-Colônia e Capivari-Monos. São Paulo: 5 Elementos, 2010.

ABRAMOVAY, Ricardo. Agricultura Familiar e o Uso do solo. São Paulo em Perspectiva, Abr/jun, vol. 11, n. ${ }^{\circ}$ 2: 73-78, 1997.

ABRAMOVAY, Ricardo. Funções e medidas da ruralidade no desenvolvimento contemporâne IPEA, Rio de Janeiro, 2000.

ABRAMOVAY, Ricardo. Subsídios e multifuncionalidade na política agrícola europeia. Economia Rural, vol.40, nº 2, pg. 235-264, abr./jun. 2002.

ABRAMOVAY, Ricardo. Paradigmas do Capitalismo Agrário em Questão, $3^{\circ}$ ed. São Paulo: Edusp, 2007.

ALMEIDA, Jalcione. A construção social de uma nova agricultura: tecnologia agrícola e movimentos sociais no sul do Brasil. Porto Alegre, Ed.Universidade/UFRGS, 1999.

ALMEIDA, J. e NAVARRO, Z. Reconstruindo a agricultura: ideias e ideais na perspectiva de um desenvolvimento rural sustentável. Porto Alegre: Ed.Universidade/UFRGS, 1998.

ALMEIDA, L. Elementos para pensar a transição agroambiental: as lógicas da mudança técnica na agricultura familiar. Desenvolvimento e Meio Ambiente. Editora UFPR, n. 14, p. 33-45, jul./dez. 2006.

ALTIERI, M. A. Agroecologia, agricultura camponesa e soberania alimentar. In Revista NERA, Presidente Prudente/SP, Ano 13 n. 16, jan/2010.

ALTIERI, M. A. Agroecologia: bases cientificas para una agricultura sustentable. Chile, Ed, Nordan-Comunidad, 1999

BARDIN, Laurence. Análise de conteúdo, Lisboa, Ed. 70, 1973 
BEDUSCHI FILHO, L. C. Assentamentos Rurais e Conservação da Natureza: do estranhamento à ação coletiva. São Paulo: Iglu, FAPESP, 2003

BEDUSCHI FILHO, L. C. Participação e Aprendizagem Social em Processos de Desenvolvimento Territorial Rural: evidências de dois estudos de caso no Brasil. Revista Econômica do Nordeste. Fortaleza, p. 259-275, v. 38, nº 2, abr./jun. 2007.

BELlENZANI, M. L. APA Municipal Capivari-Monos e Legislação de Proteção aos Mananciais na Região Metropolitana de São Paulo: estratégias complementares. s.d.

BERARDI, M. H. P. Santo Amaro. 2.a ed. In História dos bairros de São Paulo. São Paulo: Secretaria Municipal de Educação e Cultura, 1981.

BRASIL, Sistema Nacional de Unidades de Conservação - SNUC, 2000. Disponível em: $<$ http://www.mma.gov.br/areas-protegidas/sistema-nacional-de-ucs-snuc $>$. Acesso em: $01 / 02 / 2013$

BRASIL, Ministério das Cidades. Guia de elaboração de Planos Diretores. Brasília/DF, 2004

BRASIL, Ministério do Desenvolvimento Agrário. Brasília/DF, 2006

BRASIL, Ministério do Desenvolvimento Agrário. Panorama da agricultura urbana e periurbana no Brasil e diretrizes políticas para sua promoçãoo: identificaçãoo e caracterização de inciativas de AUP em Regiões Metropolitanas brasileiras. Belo Horizonte/MG, 2007

BRITO, Regina \& DEUS, J. B. A interferência da gestão municipal na produção do espaço urbano. In: Boletim Goiano de Geografia, v. 29, n. 1, p. 170-120, jan, 2009

COELHO, José Álvaro Teixeira. Setor Agrícola da Zona rural do Município de São Paulo e seu Papel na política ambiental. In: A questão Ambiental Urbana. São Paulo, SMMA, 1993.

CAPORAL, F. R., COSTABEBER, J. A. Agroecologia e desenvolvimento rural sustentável: perspectivas para uma nova extensão rural. jan./mar. Agroecologia e Desenvolvimento Rural Sustentável, Porto Alegre, v.1, n.1, p 16-37, jan/mar, 2000. 
CAPORAL, F. R., COSTABEBER, J. A. Agroecologia: matriz disciplinar ou novo paradigma para o desenvolvimento sustentável. 2006

CARVALHO, I.C.M. Qual Educação Ambiental? Elementos para um debate sobre educação ambiental e extensão rural. Agroecologia e Desenvolvimento Rural Sustentável, Porto Alegre, v.2, n.2, abr.jun.2001.

CARVALHO, Y.M.C., ZUCHIWSCHI, E., FERREIRA, S.E, FRABETTI, G.L. Pespectivas para a agricultura da Bacia do Alto Tietê. IEA/APTA, 2005. (Disponível em $<$ www.negoat.com>). Acesso: janeiro de 2013

CARVALHO, Y.M.C. et al. Agricultura: serviço ambiental para a bacia do Alto TietêCabeceiras. São Paulo em Perspectiva, São Paulo, Fundação Seade, v. 20, n. 2, p. 118135, abr.jun, 2006. (Disponível em: <http://www.seade.gov.br>; $<$ http://www.scielo.br>). Acesso: janeiro de 2013

CARVALHO, Y.M.C et al Perspectivas para a agricultura na Bacia do Alto Tietê, IEA/APTA. 2005

CAZELlA, A. BONNAL, P. e MALUF, R. (orgs.) Agricultura familiar: multifuncionalidade e desenvolvimento territorial no Brasil. Rio de Janeiro: Mauad X, 2009.

CHALITA, A. N. Agricultura familiar e seus novos vínculos com a prática econômica. In: Agriculturas, São Paulo, v.53, n.2, p. 125-139, jul, 2006

DIEGUES, Antonio C. S. O mito da natureza intocada. São Paulo, Ed. Hucitec, 2004

EHLERS, E. Agricultura sustentável: origens e perspectivas de um novo paradigma. 2 ed. Guaíba: Agropecuária, 1999

EHLERS, E. Agricultura Sustentável. In: Instituto Socioambiental. Almanaque Brasil Socioambiental. 2004

FERNANDES, Evandro Noro. Reprodução de pequenos agricultores no espaço metropolizado paulistano: uma análise da porção sul do município de São Paulo. 2008. Dissertação de Mestrado - Departamento de Geografia da Universidade de São Paulo, São Paulo, 2008. 
FERRÃO, João. Relações entre mundo rural e mundo urbano: evolução histórica, situação actual e pistas para o futuro. Revista EURE, v.26, n.78, Santiago, 2000. (Disponível em: $\quad<\mathrm{http}: / /$ www.scielo.cl/scielo.php?script=sci_arttext\&pid=S025071612000007800006>) Acesso: fevereiro 2011

FOLCH, Ramon. Sosioecologia y gobernabilidad. IN: GRASA, Rafael e ULIEDD, Andreu (Eds.). Barcelona: Icaria, 2000, p. 29-55

FREIRE, P. Pedagogia da autonomia, Ed. Paz e Terra, São Paulo, 1996

GIL, Antônio C. Métodos e técnicas de pesquisa social. São Paulo, Ed. Atlas,

GLIESSMAN, S. R. Agroecología: processos ecológicos en agricultura sostenible. Turrialba, C.R.: CATIE, 2002.

SILVA, José Graziano. O novo rural brasileiro. In: Revista Nova Economia, Belo Horizonte, v. 7, 1997, p. 43-81

SILVA, José Graziano. A nova dinâmica da agricultura brasileira, Campinas/SP, Unicamp, 1996

HANNIGAN, John. Sociologia Ambiental. Petrópolis/RJ, Ed. Vozes, 2009

HOLLANDA, Sérgio B. Raízes do Brasil. São Paulo, Ed. Companhia das Letras, 26 a ed, 1995

HOLMGREN, David. Princípios e caminhos da Permacultura além da sustentabilidade, Austrália, Ed. Holmgren Design Service, 2007 Disponível em: $<$ www.holmgren.com.au>, Acesso em fevereiro 2012

MARTINS, R. APA BORORÉ: Subsídios à implantação. Trabalho de Graduação Individual - Departamento de Geografia, FFLCH-USP. São Paulo, 2003.

LEFF, Henrique. Saber Ambiental: sustentabilidade, racionalidade, complexidade, poder. Petrópolis: Vozes, 2001

LEFF, Enrique. Epistemologia Ambiental, São Paulo: Cortez, 2001

LEFEBVRE, Henri. A revolução urbana. Minas Gerais, Ed. UFMG, 1999

LEFEBVRE, Henri. Direito a cidade. São Paulo, Ed. Humanitas, 2001 
MADALENO, I. M.; ARMIJO, G. (2004). Agricultura urbana en metrópolis iberoamericanas: estúdio de casos em Santiago de Chile y Lisboa, Portugal. In: Investigaciones Geográficas, Boletin del Instituto de Geografia. Disponível em: $<$ http://redalyc.uaemex.mx/redalyc/pdf/ 569/56905404.pdf $>$. Acesso em: 21 ago. 2006.

MARICATO, E. O nó na terra. In Revista Piauí, junho 2008

MARICATO, E. Formação e impasse do pensamento crítico sobre a cidade periférica, São Paulo, 2010

MARTINEZ-ALIER, Joan. Ecologismo dos pobres, Ed. Contexto, 2007

MAZOYER, M.; ROUDART, L. História das agriculturas no mundo: do neolítico a crise contemporânea. São Paulo, Unesp, 2010.

MONT-MÓR, R. L. O que é urbano no mundo contemporâneo. Belo Horizonte?MG, UFMG, 2004

MORIN, Edgar. Ciência com consciência, São Paulo, Ed. Bertrand Brasil, 2005

MOUGOET, L. J. A. Agricultura urbana: conceito e definição. 2000. (Disponível em: $<$ www.ruaf.org $>$ ) Acesso: fevereiro de 2011

OLIVEIRA, F. Crítica à razão dualista, o ornitorrinco. São Paulo, Ed. Botempo, 2003

PIES, Marcelino. A Agricultura Familiar no contexto da Região de Produção. In: CONTI, Irio Luiz; PIES, Marcelino, CECCONELLO, Rene (orgs.). Agricultura Familiar: caminhos e transições. Passo Fundo: IFIBE, 2006.

RAIMUNDO, S. A paisagem natural remanescente na Região Metropolitana de São Paulo. São Paulo em Perspectiva, v. 20, n. 2, p.19-31, abr./jun. 2006.

RIBEIRO, D. O povo brasileiro, 2006: a formação e o sentido do Brasil. $2^{\mathrm{a}}$ ed, São Paulo, Companhia das Letras, 1995

RODRIGUES, E.A.; VICTOR, R.A.B.M.; PIRES, B.C.C. A reserva da biosfera do cinturão verde na cidade de São Paulo como marco para a gestão integrada da cidade, seus serviços ambientais e o bem estar humano. In: Perspectiva, São Paulo, v. 20, n. 2, p. 71-89, abr.jun. 2006. 
SCHNEIDER, Sérgio; CAZELLA, Ademir Antonio; MATTEI, Lauro. Histórico, caracterização e dinâmica recente do Pronaf - Programa de Fortalecimento da Agricultura Familiar. In: SCHNEIDER, Sérgio; SILVA, Marcelo K.; MARQUES, Paulo E. Moruzzi. (orgs) Políticas Públicas e Participação Social no Brasil Rural. Porto Alegre, UFRGS, 2004.

SCHNEIDER, Sérgio. Teoria Social, agricultura familiar e pluriatividade. In: Revista Brasileira de Ciências Sociais, v. 18, n. 51, 2002

SACHS, Ignany. Brasil rural: da descoberta à invenção. Revista de Estudos Avançados, v15, nº 43, São Paulo, 2001.

SACHS, Ignany. Rumo à ecossocioecomonia, Ed. Cortez, 2007

SANTOS, Boaventura. Pela mão de Alice: o social e o político na pós-modernidade. São Paulo: Cortez, 1995

SANTOS, Milton. Da totalidade ao lugar. Ed. EDUSP, São Paulo, 2008.

SANTOS, Milton. A natureza do espaço. Ed. EDUSP, São Paulo, 2008.

SÃO PAULO. Secretaria Municipal do Verde e do Meio Ambiente/ Secretaria de Planejamento. Atlas Ambiental do Município de São Paulo: o verde, o território, o ser humano: diagnósticos e bases para a definição de políticas públicas para as áreas verdes do Município de São Paulo. São Paulo, 2004a

SÃO PAULO, Secretaria Municipal do Verde e do Meio Ambiente. Geo cidade de São Paulo: panorama do meio ambiente urbano. Brasília: PNUMA, 2004b

SÃO PAULO, Secretaria Municipal do Verde e do Meio Ambiente / Secretaria de Planejamento. Atlas Ambiental do Município de São Paulo: o verde, o território, o ser humano: diagnósticos e bases para a definição de políticas públicas para as áreas verdes do Município de São Paulo. São Paulo, 2004c

SÃO PAULO, Secretaria do Verde e do Meio Ambiente. Seminário Guarapiranga: proposições de ações prioritárias para garantir água de boa qualidade para abastecimento público. São Paulo, 2006 
SÃO PAULO, Secretaria do Verde e Meio Ambiente. Diagnóstico socioambiental preliminar da Área de Proteção Ambiental Bororé-Colônia. São Paulo, 2007

SÃO PAULO, Secretaria do Verde e do Meio Ambiente/Centro de Estudos da Metrópole. Manaciais: uma nova realidade?, São Paulo, Instituto Socioambiental, 2008

SÃO PAULO. Secretaria do Verde e do Meio Ambiente/Centro de Estudos da Metrópole. Indicadores ambientais e gestão urbana: desafios para a construção da sustentabilidade na cidade de São Paulo. São Paulo, 2008b

SÃO PAULO, Secretaria do Verde e do Meio Ambiente. Plano de Manejo APA Capivari-Monos. São Paulo, 2011

SÃO PAULO, Secretaria do Verde e do Meio Ambiente. Guia dos Parques Municipais de São Paulo. São Paulo, 2013

SEMINÁRIO BILLINGS, Avaliação e identificação de áreas e ações prioritárias para a conservação, recuperação e uso sustentável da Bacia Hidrográfica Billings, São Paulo, Instituto Socioambiental, 2002

SANTORO, P. F. Planejar a expansão urbana: dilemas e perspectivas. 2012. 360f. Tese (Doutorado) Faculdade de Arquitetura e Urbanismo da Universidade de São Paulo, São Paulo, 2012

SIXEL, B. T. O que é agricultura biodinâmica? Disponível em: <http://sab.org.br/agricbiod/ABmainFrame.htm>, publicado em 2003. Acesso em: fev 2012.

SILVA, José Graziano. O novo rural brasileiro. In: Revista Nova Economia, Belo Horizonte, v. 7, 1997, p. 43-81

SILVA, José Graziano. A nova dinâmica da agricultura brasileira, Campinas/SP, Unicamp, 1996

STEINER, Rudolf. Fundamentos da Agricultura Biodinâmica, Botucatu/SP, Ed. Antroposófica, 1924

VALE, Ana Rute. Expansão urbana e plurifuncionalidade no espaço periurbano do município de Araraquara (SP). Tese (Doutorado) do Programa de Pós-Graduação em Geografia, Rio Claro/SP, 2005 
VALETTE, E. (2004). A economia rural periurbana ou inovação em periferia: o caso de Montpellier. Disponível em: <http://www.desenvolvimentolocal.ucdb.br/ RevistaInteracoes/n8_elodie_1.PDF>. Acesso em: julho 2006.

VEIGA, José Eli da. A face rural do desenvolvimento: natureza, território e agricultura. Porto Alegre: Ed. Universidade/ UFGRS, 2000.

VEIGA, José Eli da. O desenvolvimento agrícola: uma visão histórica. $2^{\circ}$ ed. São Paulo: Edusp, 2007.

VEIGA, José Eli da. A Atualidade da contradição urbano-rural. In: Análise territorial da Bahia Rural, SEI, Série Estudos e Pesquisas, n. 71, 2004

VILLAÇA, Flávio. Espaço Intraurbano. São Paulo, Ed. Nobel, 2001.

TEIXEIRA, O. (orgs.). Planejamento do Desenvolvimento dos Territórios Rurais: conceitos; controvérsias e experiências. UFPB/CIRAD/EMBRAPA, Brasília, 2002

THIOLLENT, Michel. Metodologia da pesquisa-ação. São Paulo, Ed. Cortez, 2009

TRIGAL, L. L. Últimas tendencias migratórias en Espaã y sus repercusiones en las áreas urbanas In: Revista da Faculdade de Letras da Universidade do Porto, Geografia. - ISSN 0871-1666. - I série, vol. XIX (2003), p. 283-294

LÓPEZ TRIGAL, L. Ciudades y periferias sostenibles. Una revisión de conceptos y enfoques aplicados a España y Catilla y León. Geoinova. n. 7, Lisboa, 2003, p.59-74.

ZENHA, E. A Vila de Santo Amaro. São Paulo: Instituto Histórico e Geográfico de São Paulo, 1977. 